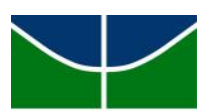

UnB

Instituto de Ciências Biológicas

Programa de Pós-graduação em Ecologia

\title{
Mudanças do uso da terra sobre a comunidade de formigas e a retenção dos serviços ecossistêmicos no Cerrado
}

Aluno: Tiago Luiz Massochini Frizzo

Orientador: Edison Ryoiti Sujii 
Agradeço em primeiro lugar a todos educadores que passaram pela minha vida, conhecimento, compreensão e aprendizado são partes fundamentais para admirar a beleza do mundo.

Em especial gostaria de agradecer ao orientador desta tese, Edson Ryoitti Sujii, pela presença, apoio e discussões que levaram ao melhoramento da tese. Ao meu primeiro orientador durante a graduação, Heraldo L. Vasconcelos, que na prática foi quem me inseriu na vida acadêmica. Aos meus estagiários, sem os quais não conseguiria ter completado a parte física do trabalho: Maísa Meneses, Antônio, Karina e Letícia. Aos colegas da Embrapa Cenargen: Lucas, Érica, Pedro, entre muitos outros, além dos pesquisadores que também contribuíram muito para o desenvolvimento desta tese. Agradeço também aos meus colegas do Laboratório de Ecologia em Insetos Sociais da Universidade Federal de Uberlândia, principalmente a Renata Pacheco, pela ajuda na identificação das espécies de formigas e conversas a respeito da tese. Aos inúmeros proprietários de terras que permitiram que eu fizesse amostragens em suas propriedades, incluindo também o Instituto Brasília Ambiental (IBRAM), Fazenda Água Limpa da UnB, Estação Ecológica do Jardim Botânico de Brasília, Estação Ecológica de Águas Emendadas, Parque Nacional de Brasília, Embrapa Hortaliças, Embrapa Cerrados e o Instituto Federal de Brasília. Também agradeço a Capes e CNPq pelo financiamento do projeto e bolsa de estudo.

Por último, gostaria de ressaltar meus agradecimentos especiais aos meus pais, Luiz Antônio Frizzo e Leoni Massochini, que me encorajaram e financiaram durante o doutorado, sem os quais com certeza teria tido uma trajetória muito mais difícil. Além da minha noiva, Carla Érica Oliveira Ferreira, que me deu e me dá suporte emocional, tornando a vida mais fácil, diminuindo às angústias e buscando um futuro melhor. 


\section{Resumo}

Muitos estudos têm relatado que vivenciamos um período de extinção em massa, principalmente devido à expansão dos sistemas agrícolas. Aliado a isso, tem-se demonstrado que a diminuição na biodiversidade pode causar perda ou redução das funções do ecossistema, gerando problemas de diversas naturezas. Por isso nós buscamos explorar os efeitos da conversão de áreas nativas do Cerrado em sistemas agrícolas sobre a fauna de formigas. Para isso realizamos amostragens e experimentos que contemplaram 74 localidades diferentes no Distrito Federal. Os locais de coleta foram cultivos convencionais de soja, pastagens, áreas de agricultura orgânica e áreas com vegetação nativa de campo, cerrado stricto sensu e mata. Foram feitos 5.298 registros de formigas e encontradas 265 espécies. Constatamos que as pastagens e áreas de agricultura orgânica abrigam $61 \%$ e $56 \%$ da mirmecofauna nativa respectivamente, enquanto que as áreas de cultivo convencional de soja abrigam apenas $17 \%$ das espécies nativas de formigas. Detectamos que as espécies raras (i.e. com baixa frequência) foram as principais promotoras de diversidade de formigas no Cerrado, e potencialmente as mais ameaçadas de extinção local, devido à baixa densidade e raridade dentro dos agrossistemas. Quanto às funções do ecossistema desempenhadas pelas formigas, utilizamos uma abordagem experimental e encontramos que a remoção de biomassa de recursos que simulam organismos animais (sardinha) e atrativos vegetais (banana), na superfície do solo, está correlacionada à riqueza de formigas. Além disso, mostramos que nas áreas de produção orgânica de hortaliças as formigas predam mais do que o dobro de ovos do inseto praga Anticarsia gemmatalis (Lepidoptera: Noctuidae) que os outros predadores. Vimos também que os efeitos das formigas sobre as funções do ecossistema dependem da função do ecossistema avaliada, do tipo de uso da terra e da riqueza de formigas no local. Resumidamente encontramos que a expansão da agricultura reduz a diversidade de formigas, sendo esse efeito particularmente maior na soja. Concluímos que a perda dessa diversidade pode afetar negativamente funções e serviços do ecossistema e que medidas de conservação devem focar na proteção de múltiplas fitofisionomias nativas.

Palavras-chave: Hymenoptera, Formicidae, Controle biológico, Intensificação do uso da terra, perturbações, agroecossistemas. 


\begin{abstract}
Human activities, especially the expansion of agroecosystems, are appointed by studies as the mainly cause of extinction. The ecological consequences of biodiversity loss usually are the reduction of ecosystem functions. However, these responses vary according to the type of land-use change and the ecological setting. This study measured the impact of land-use type and ecosystem functions on the ant assemblage of Cerrado biome. Ant composition was assessed in 74 different locations in the Federal District (Brazil). The collected sites were conventional crops of soybeans, pastures, organic farms and native vegetation, including grassland, cerrado stricto sensu (savanna) and forests. We record 5,298 ants and 265 species. The pastures and organic farm hold $61 \%$ and $56 \%$ of the native ant fauna respectively, while soybean crop have only $17 \%$ of the native species of ants. We found that rare species (i.e. low frequency) were the main promoters of ant diversity in the Cerrado, and potentially the most threatened by local extinction due to low density and rarity in the agroecosystems. For measure functions performed by the ants, we use an experimental approach. We found that removing biomass resource simulating animal organisms (sardines) and vegetables attractive (banana) on the soil surface, is correlated with ant species richness. Furthermore, we show that ants prey more than twice folds the eggs of insect pest Anticarsia gemmatalis (Lepidoptera: Noctuidae) than the other predators in organic farms. Indicating that the effects on ecosystem functions, provided by ants are dependent to the: ecosystem function feature, the land-use type and ant richness. Overall, our results found that agricultural expansion reduces the ant diversity, particularly in soybeans crops, and can affect ecosystem functions. To mitigate the reduction in the ant assemblage, we recommend the conservation of multiple natural habitats.
\end{abstract}

Keywords: Hymenoptera, Formicidae, Biological Control, Land use intensification, Disturbance, Savanna. 


\section{Sumário}

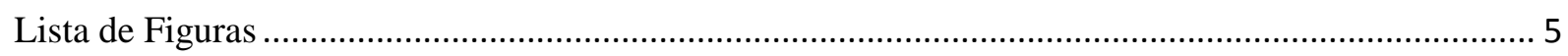

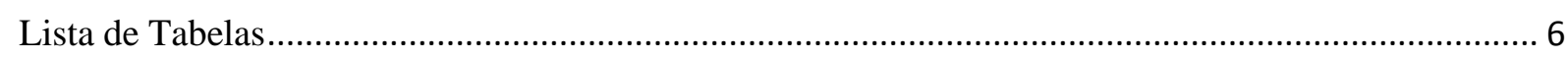

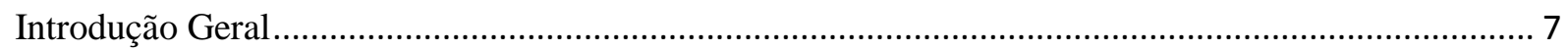

Capítulo I - Efeitos da mudança no uso da terra sobre a comunidade de formigas do solo ................. 14

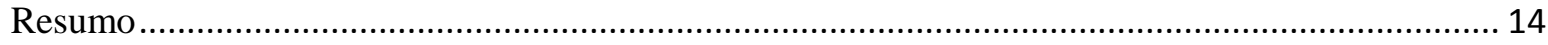

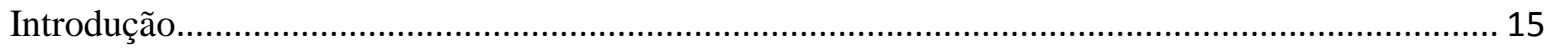

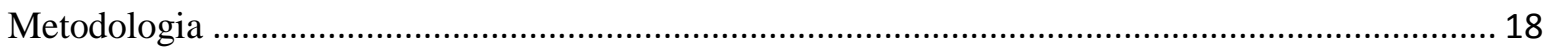

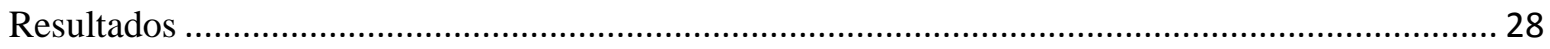

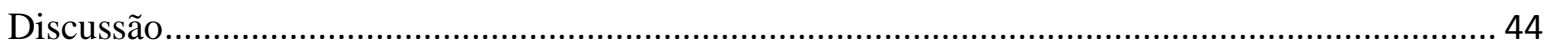

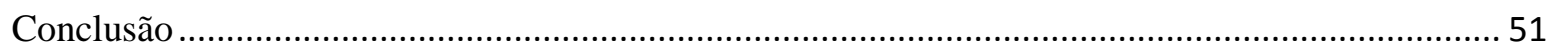

Capítulo II - Variação nas taxas de remoção de biomassa pela mirmecofauna de solo sobre diferentes

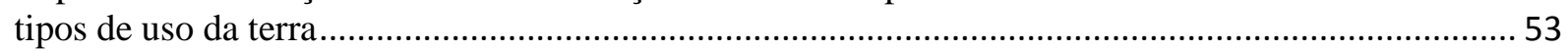

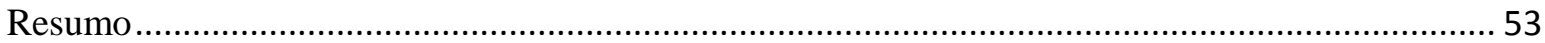

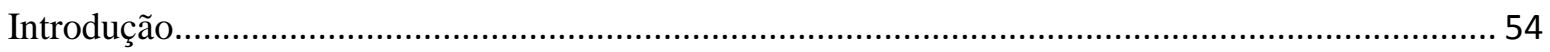

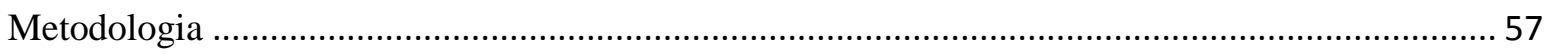

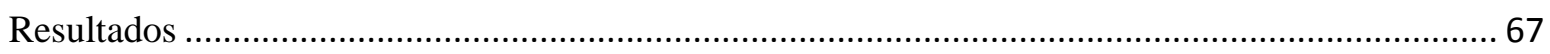

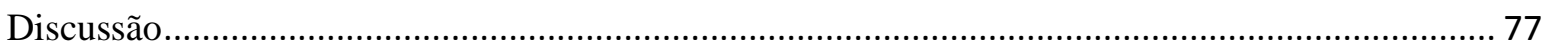

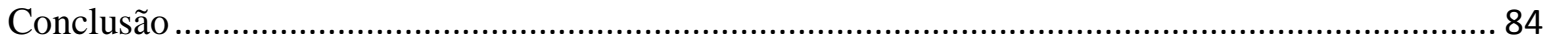

Capítulo III - Contribuição das formigas (Hymenoptera: Formicidae) para a predação de ovos de lagarta em sistemas orgânicos de produção de hortaliças ..................................................................... 85

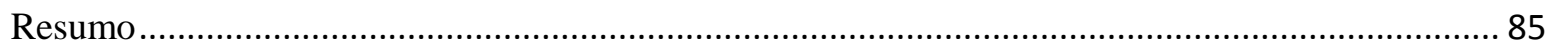

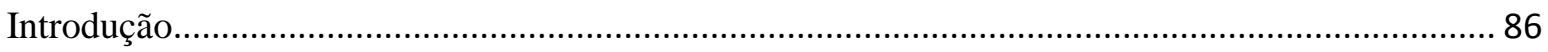

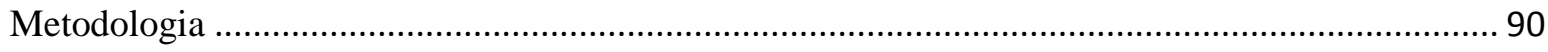

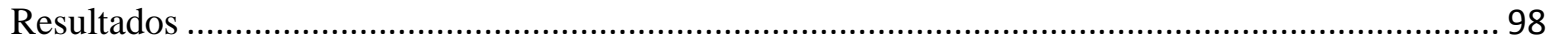

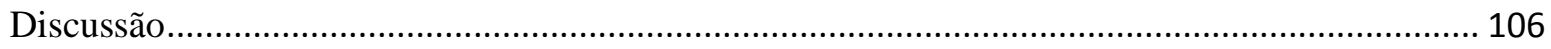

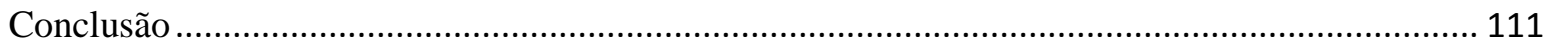

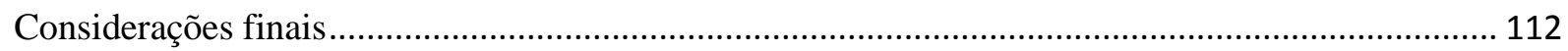

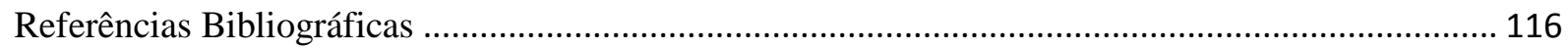

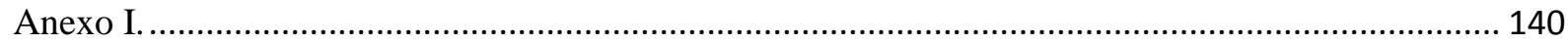

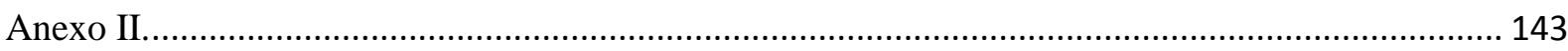

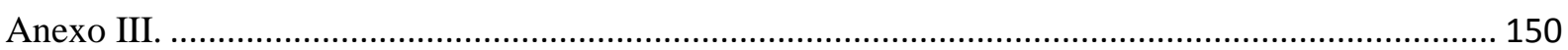

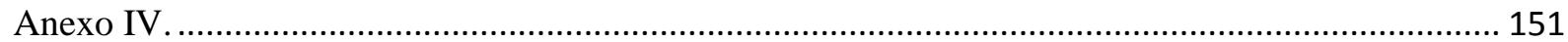




\section{Lista de Figuras}

\section{Capítulo I}

Figura 1.1 Mapa da área de coleta no DF. 25

Figura 1.2 Fotografias das áreas de coleta.. 26

Figura 1.3 Esquema da metodologia de coleta.......................................................... 27

Figura 1.4 Curva de acumulo de espécies................................................................ 32

Figura 1.5 Curva de riqueza estimada............................................................... 32

Figura 1.6 Número médio de espécies amostradas................................................... 33

Figura 1.7 Ocorrência de formigas por tipo de habitat.................................................. 33

Figura 1.8 Distribuição por habitat da frequência de ocorrência................................. 34

Figura 1.9 Ocorrência das espécies............................................................................ 35

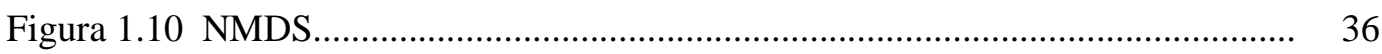

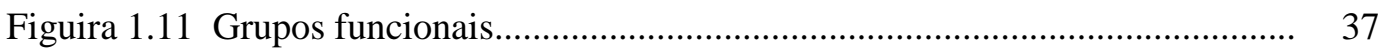

Figura 1.12 Análise da partição aditiva.................................................................... 38

Figura 1.13 Análise da partição multiplicativa...................................................... 39

Figura 1.14 Relação entre a diversidade e distância geográfica.................................. 40

\section{Capítulo II}

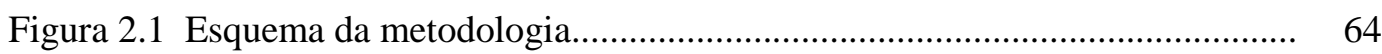

Figura 2.2 Fotografias da metodologia........................................................................ 65

Figura 2.3 Proporção de estações de remoção com formigas........................................ 70

Figura 2.4 Biomassa removida............................................................................... 71

Figura 2.5 Correlação entre biomassa e riqueza de formigas...................................... 72

Figura 2.6 Matriz de correlação............................................................................. 73

Figura 2.7 Matriz de correlação sem os dados para soja............................................ 74

Figura 2.8 CCA para todas as espécies............................................................... 75

Figura 2.9 CCA apenas para as espécies abundantes............................................. 76

\section{Capítulo III}

Figura 3.1 Mapa da localização dos experimentos...................................................... 95

Figura 3.2 Fotografia da metodologia..................................................................... 96

Figura 3.3 Proporção das guildas tróficas.................................................................... 100

Figura 3.4 Proporção dos táxons de predadores....................................................... 101

Figura 3.5 Número de ovos predados....................................................................... 102

Figura 3.6 Regressões e correlação com a abundância............................................... 103 


\section{Lista de Tabelas}

\section{Capítulo I}

Tabela 1.1 Localidades amostradas................................................................ 23-24

Tabela 1.2 Valores indicativos (IndVal),......................................................... 41-43

\section{Capítulo II}

Tabela 2.1 Número de estações de biomassa........................................................ 66

\section{Capítulo III}

Tabela 3.1 Localização das propriedades............................................................... 97

Tabela 3.2 Porcentagem de ocorrência das paisagens.......................................... 97

Tabela 3.3 Lista de espécies............................................................................. 104

Tabela 3.4 Resultados da análise de modelos................................................... 105 


\section{Introdução Geral}

Atualmente dois dos maiores desafios da ciência são identificar os impactos da atual taxa de extinção de espécies e garantir a segurança alimentar da população humana. Apesar de serem dois temas de pesquisa sem aparente conexão, a expansão dos sistemas agrícolas aliados à fragmentação resultante deste processo é a maior causa de extinção de espécies conhecida (Pimm et al. 1995; Didham et al. 1996; Sala et al. 2000; Fahrig 2003; Rockströn et al. 2009; Barnosky et al. 2011; Bregman et al. 2015; Newbold et al. 2015). Ao mesmo tempo, a extinção também pode ter efeitos negativos sobre a produção agrícola (e.g. Larsen et al. 2005; Brittain \& Potts 2011). Isso aponta para a necessidade de se aprimorar ou criar tecnologias que permitam o aumento da produção agrícola reduzindo a possibilidade de extinção de espécies nativas, bem como a de gerar dados consistentes para tomada de decisão visando à sustentabilidade.

Pimm et al. (1995) já alertavam que, para alguns táxons, entre 5 e 20\% das espécies já teriam sido extintas. Mais recentemente, Barnosky et al. (2011) afirmam que, nos próximos três séculos, podemos atingir o status de extinção em massa com a perda de $75 \%$ das espécies do planeta, sendo que as estimativas mais recentes apontam que conhecemos apenas $13 \%$ das aproximadamente 10.960.000 espécies (eucariotas) existentes no planeta. Portanto estamos perdendo espécies que ainda sequer foram descritas (Mora et al. 2011).

Hoje, muitos cientistas acreditam que estamos vivenciando o sexto período de extinção em massa devido à atividade humana principalmente no que concerne à agricultura e sua expansão (Chapin et al. 2000; Wake \& Vredenburg 2008). Em vista disso, é necessário destacar que essa expansão é e deve continuar sendo um fato, já que há um aumento da demanda por alimento, devido não só ao crescimento populacional do planeta, mas também ao aumento no consumo de alimento per capita (FAO 2009; UNPD 2011). Além disso, há 
outros fatores que contribuem para a expansão da agricultura, tais como o incremento da produção de biocombustíveis e outros produtos não alimentícios (Groom et al. 2008; Popp et al. 2013), da degradação de zonas agrícolas existentes, dos imprevisíveis efeitos das mudanças climáticas sobre a produção de alimento nos próximos anos, das restrições cada vez maiores sobre o uso de agrotóxicos e o aumento do custo de transporte (Tscharntke et al. 2012). Logo, esse cenário apresenta muitos atributos fortes para agravar as taxas de extinção de espécies.

Mas quais são as consequências de acelerar essas taxas de extinção de espécies? O primeiro, e talvez menos considerado pela sociedade, é: qual o direito que nós (humanos) temos de eliminar uma espécie do planeta? Este é ou pelo menos deveria ser um argumento poderoso para a preservação de espécies (Ehrlich 2002). O segundo é que os estudos apontam que a extinção de espécies geralmente causa a perda ou redução de funções do ecossistema, incluindo serviços ecológicos, no entanto esse não é um padrão universal, o que gera muito debate (De Fries et al. 2004; Hopper et al. 2005; Larsen et al. 2005; Balvanera et al. 2006; Loreau et al. 2008; Cardinale et al. 2006; Benayas et al. 2009; Duffy 2009; Allan et al. 2013).

Funções do ecossistema podem ser definidas como a capacidade de processos naturais e componentes de prover bens e serviços que satisfazem as necessidades humanas, direta ou indiretamente (De Groot 1992). Primariamente esses processos e bens ocorrem com a assimilação da energia solar pelos fotossintetizantes e a redistribuição desta energia por toda cadeia alimentar até chegar aos decompositores. Durante essa passagem de energia há uma infinidade de processos e trocas físico-químicas (envolvendo também o meio abiótico) que moldam o nosso mundo da forma como é hoje. São exemplos de funções do ecossistema: a produção primária, a decomposição, a ciclagem de nutrientes, a filtragem da água, a predação, refúgio para a vida silvestre, alimento que não é cultivado, recreação entre outros (De Groot 1992; Daily et al. 1997). Logo, quando uma determinada função do ecossistema passa a 
produzir um benefício capaz de ser valorado para os humanos, passamos a chamá-la de serviço ou bens do ecossistema (De Groot et al. 2002). Como exemplos destes, podemos citar: a polinização de culturas, o controle biológico de pragas, a fertilização promovida por agentes bióticos, a disponibilidade de alimentos nas áreas naturais, a disponibilidade de água potável entre outros (Daily et al. 1997).

Apesar da extinção de espécies gerar a perda ou redução de serviços ecológicos (e.g. Larsen et al. 2005; Cadotte et al. 2012; Boyer \& Jetz 2014; Birkhofer et al. 2015; Mensens et al. 2015; Van der Plas et al. 2016), há também estudos que indicam a possibilidade de, por meio do uso de diferentes tipos de métodos, aumentar a riqueza de espécies incrementando as funções do ecossistema e serviços ecológicos em ambientes manejados (e.g. Langellotto \& Denno 2004; Tiemann et al. 2015).

No entanto, nem sempre é encontrada uma relação entre o número de espécies e funções do ecossistema (e.g. Radchuck et al. 2016), pois as extinções podem não ter efeitos imediatos, porque as espécies mais propensas à extinção já são populações naturalmente pequenas e de distribuição restrita ou porque outras espécies já desempenham a mesma função (redundância) no ecossistema (Hooper et al. 2005). Entretanto, parece ser um consenso que uma alta riqueza de espécies é importante em termos de estabilidade de funções ou serviços, em caso de distúrbios ou mudanças ambientais (Hooper et al. 2005; Tscharntke et al. 2005; Loreau et al. 2008).

$\mathrm{Na}$ natureza, em contrapartida, as espécies desaparecem de acordo com sua sensibilidade a estresses ambientais (e.g. Bregman et al. 2015). Mensens et al. (2015), em um estudo utilizando comunidades de diatomáceas expostas ao herbicida Atrazina, observaram uma pequena perda de biodiversidade ocasionando uma perda desproporcional das funções no ecossistema (produção primária, conteúdo energético e estabilização de sedimento). Isso porque Atrazina afeta principalmente a espécie que apresenta a maior produtividade dentro do 
sistema, demostrando que a sensibilidade de uma espécie específica deve ser levada em consideração para se prever efeitos de distúrbios sobre as funções do ecossistema em áreas sobre estresse antrópico.

Para o Brasil, a expansão da agricultura devido à crescente demanda do mercado de exportação do agronegócio, que já atingiu $43 \%$ do valor total exportado pelo país e $26 \%$ do PIB (MAPA 2016a), acaba se tornando a maior ameaça para o Cerrado (Klink \& Machado 2005; Silva et al. 2006; Sano et al. 2010). Essa ameaça, aliada ao alto número de espécies endêmicas nesse bioma, faz do Cerrado um dos hotspots do mundo, contendo $1,5 \%$ das espécies de plantas vasculares do planeta, o que corresponde a 10.000 espécies, dentre as quais 4.400 são endêmicas (Myers et al. 2000).

Antes de 1970, o uso da terra no Cerrado era basicamente para a produção de gado sobre pastagens naturais (Sano et al. 2010). A partir de então, se iniciou uma intensa expansão da produção agrícola mecanizada para exportação de soja, milho, algodão e café (Jepson 2005; Klink \& Machado 2005). Estima-se que, devido à expansão agrícola, entre $40 \%$ e $80 \%$ da área natural de Cerrado foi convertida em agrossistemas durante as últimas cinco décadas (Cavalcanti \& Joly 2002; Klink \& Moreira 2002; Machado et al. 2004; Brannstrom et al. 2008). No entanto, essas estimativas são muito variáveis devido a dificuldades para se discriminar nas imagens de satélite o que são áreas de vegetação nativa e áreas de pastagem (Ferreira et al. 2004).

Segundo Sano et al. (2010), em 2002, pastagens eram o maior tipo de uso da terra do Cerrado, pois ocupavam uma área de 54.150 .000 de ha, representando cerca de $26 \%$ da área desse bioma. Já o segundo maior uso da terra, desse mesmo bioma, é para a agricultura, na qual a soja ocupa um pouco menos da metade da área (MAPA 2016b), totalizando 21.590.000 de ha (mais de $10 \%$ da área do Cerrado). E, apesar de áreas agrícolas de produção orgânica não serem representativas nas estatísticas, a agricultura orgânica é, seguramente, um dos 
setores que mais crescem no Brasil e no mundo (Rigby \& Cáceres 2001; Blanc 2009; ABRASCO 2015).

Esses três tipos de agrossistemas se diferenciam pelo tipo de manejo e composição da vegetação, sendo que as principais características das áreas de plantio de soja são seu manejo intensivo com agrotóxicos e o plantio de uma monocultura extensiva, que pode ser alternada principalmente com o plantio de milho, sorgo ou milheto, e que geralmente está restrita às épocas de chuva. Inversamente, em áreas de agricultura orgânica, geralmente os cultivos ocupam poucos ha, o uso de agrotóxicos é ausente, há um intenso manejo do solo com capina e, devido à irrigação constante, há o plantio de uma grande variedade de hortaliças ao longo de todo ano. Já as pastagens certamente são as áreas com menor manejo ou, na maior parte do tempo, sem manejo que, apesar de serem originalmente plantadas como uma monocultura de capim (sendo o Urochloa (Syn. Brachiaria) decumbens, uma espécie exótica e a mais comum), podem ser colonizadas por algumas ervas, arbustos e/ou árvores nativas em seus campos. Mesmo sendo a soja a cultura que mais cresce no Cerrado (Fearnside 2001; MAPA 2016a), espera-se que as áreas de agricultura orgânica ocupem cada vez mais espaço na produção de alimentos (Rigby \& Cáceres 2001; Blanc 2009; ABRASCO 2015).

Tendo em vista que as perspectivas para 2050 são de expansão dos agrossistemas sobre 120 milhões de hectares de áreas de vegetação nativa, nos países em desenvolvimento (FAO 2009), é imperativo que se conheça os efeitos da conversão de terras em agrossistemas sobre a biodiversidade e se descubra como reduzir a perda de espécies (Tscharntke et al. 2005; Balmeford et al. 2012). Sendo assim, como apresentado por Tscharntke et al. (2005) em uma revisão, já sabemos que os efeitos da mudança no uso da terra podem ser percebidos de formas diferentes, dependendo do grupo taxonômico, da espécie e do tipo de uso da terra (e.g. Perfecto et al. 2004; Armbrecht et al. 2006; Kessler et al. 2009; Frizzo \& Vasconcelos 2013). 
Dentre os organismos encontrados nos ecossistemas terrestres, as formigas são um grupo de particular importância ecológica (Folgarait 1998). Na Amazônia a sua biomassa é maior do que a biomassa somada de todos os vertebrados, incluindo-se pássaros, mamíferos, anfíbios e répteis (Fittkau \& Klinge 1973). Hölldobler e Wilson (2009) chegam a afirmar que a biomassa de formigas no mundo é tão grande que pode equiparar-se com a dos humanos. Porém, estes organismos não são apenas abundantes, geralmente eles apresentam hábitos predatórios e, assim, podem atuar no controle de insetos, incluindo aqui aqueles que são prejudiciais à agricultura (Risch \& Carroll 1982; López \& Potter 2000; Philpott \& Armbrecht 2006; Armbrecht \& Gallego 2007; Howe et al. 2009; Styrsky \& Eubanks 2010; Gonthier et al. 2013; Offenberg 2015). Há também espécies consideradas importantes pragas agrícolas, como as formigas da tribo Attini, que funcionalmente atuam como herbívoras (Hernandez \& Jaffé 1995; Costa et al. 2008; Zanetti et al. 2014), e várias outras espécies que se associam mutualisticamente com afídeos (insetos parasitas de plantas) (Delabie 2001; Styrsk \& Eubanks 2007). Por essa importância ecológica, aliada a taxonomia relativamente bem conhecida e ampla ocorrência, esse grupo foi escolhido como objeto de estudo do presente trabalho.

Frizzo \& Vasconcelos (2013), em um estudo no Cerrado, apontam que a conversão da vegetação nativa em pastagem não afeta a mirmecofauna (fauna de formigas). Por outro lado, a conversão dessa vegetação em plantio de soja tem um efeito negativo no número de espécies, ocasionando ainda mudanças na composição de espécies de formigas (Frizzo \& Vasconcelos 2013; Pacheco et al. 2013). De modo geral, os estudos apontam que mudanças na estrutura do habitat e o manejo são as principais causas dessas mudanças. Mais especificamente, a redução de local para nidificação das formigas, arar o solo, uso de agrotóxicos, além de efeitos indiretos, como a interação interespecífica com formigas dominantes que limitam a coexistência com outras espécies, têm sido apontados como os 
principais fatores da redução do número de espécies de formigas nos agrossistemas do Cerrado (Frizzo \& Vasconcelos 2013; Pacheco et al. 2013). Pacheco et al. (2013) também indicam que as espécies que persistem nos agrossistemas de soja em geral são um subconjunto das espécies associadas às savanas mais abertas, além de que a maior parte das formigas que desaparecem são aquelas que apresentam comportamento mais especializado (sensu Didham et al 1996; Weiner et al. 2014; Bregman et al. 2015). No entanto, ambos os trabalhos já realizados no Cerrado, de Frizzo \& Vasconcelos (2013) e Pacheco et al. (2013), relatam que o número de espécies perdidas com a mudança no uso da terra podem estar subestimados devido à coleta próxima de locais potencialmente fontes de espécies de formigas.

Em vista disso, o objetivo geral desse estudo foi determinar como as mudanças no uso da terra afetam a comunidade de formigas e suas funções ecológicas. Especificamente procuramos determinar quantas e quais são as espécies que conseguem persistir em áreas convertidas em agrossistemas comparativamente às áreas de vegetação nativa e quais os tipos de agrossistema têm um menor impacto sobre essa fauna. Além disso, queremos determinar se após a conversão da vegetação nativa em agrossistemas há uma redução nos serviços ecológicos prestados pela mirmecofauna de remoção de biomassa e predação. 
Capítulo I - Efeitos da mudança no uso da terra sobre a comunidade de formigas do solo

\section{Resumo}

É um consenso entre os pesquisadores que os sistemas agrícolas reduzem a biodiversidade. No entanto, a magnitude desse efeito depende das características do sistema agrícola implantado e do grupo taxonômico sujeito a essa perturbação. Por isso foi analisado como três diferentes tipos de uso da terra (cultivo de soja, pastagem e produção orgânica de hortaliças) afetam a comunidade de formigas, amostrando, para isso, 69 localidades, que incluíram áreas nativas de campo, cerrado stricto sensu e mata. Ao todo, coletamos 264 espécies de formigas, na superfície do solo no Distrito Federal, onde se estima ocorrer em torno de 342 a 354 espécies. As pastagens e áreas de agricultura orgânica abrigam 61\% e 56\% da mirmecofauna nativa, respectivamente, enquanto que as áreas de cultivo convencional de soja abrigam apenas $17 \%$ das espécies nativas de formigas. As áreas de formação florestal apresentam a comunidade mais singular. Já as áreas de soja apresentam o padrão mais forte de homogeneização biótica. Detectamos também que são as espécies raras (de baixa frequência) os principais promotores de riqueza no Cerrado e, potencialmente, as mais ameaçadas de extinção local, devido a essa baixa densidade e pouca ocorrência nos agrossistemas. Nossos dados sugerem de modo geral que o cultivo de soja convencional é a principal ameaça à mirmecofauna no Cerrado e medidas de conservação devem focar na proteção de múltiplas fitofisionomias nativas. 


\section{Introdução}

Tradicionalmente os esforços de conservação têm sido focados em grupos de plantas e vertebrados. Myers et al. (2000), por exemplo, usaram apenas plantas vasculares e vertebrados para determinar os "hotspots" do planeta. No entanto, estes grupos representam proporcionalmente uma pequena parte da biodiversidade e a mais conhecida em termos de espécies descritas (Mora et al. 2011). Já os insetos, que representam seguramente a maior parte da biodiversidade animal, têm sido negligenciados nos estudos de conservação, talvez devido ao grande número de espécies e/ou à dificuldade para se identificar estas espécies, que podem, em muitos casos, ainda não terem sido descritas (Mora et al. 2011).

Os insetos são um grupo de grande importância nos ecossistemas, influenciando a composição e tamanho das populações de plantas, herbívoros, predadores e detritívoros (Wheeler 1990; Didham et al. 1996). Especificamente no Cerrado, a comunidade de insetos é influenciada pelo fogo (Frizzo et al. 2011; Maravalhas \& Vasconcelos 2014), heterogeneidade da vegetação (Silva et al. 2006; Pacheco \& Vasconcelos 2012), sazonalidade (Pinheiro et al. 2008), fragmentação (Brandão et al. 2011), introdução de espécies exóticas (Pivello et al. 1999; Hoffmann et al 2004) e, principalmente nas últimas décadas, pelos efeitos da mudança no uso da terra (Almeida et al. 2011; Frizzo \& Vasconcelos 2013; Pacheco et al. 2013), entre outros fatores.

Em geral, a conversão de terras em agrossistemas tem sido vista, tradicionalmente, como antagônica à conservação da biodiversidade (Tscharntke et al. 2005). Em parte, porque a maioria dos sistemas agrícolas é derivada da conversão de ecossistemas naturais complexos para os ecossistemas simplificados, com uso intenso de maquinário, insumos químicos e biológicos, incluindo culturas melhoradas e geneticamente modificadas (e.g. Pimental et al. 1992; Groot \& Dicke 2002; Armbrecht et al. 2006; Haddad et al. 2009; Frizzo \& Vasconcelos 
2013). Estes agrossistemas são a maior causa de perda de biodiversidade devido à fragmentação e destruição da vegetação nativa (Didham et al 1996; Fahrig 2003; Bregman et al. 2015). No entanto, os efeitos da mudança no uso da terra sobre a fauna nativa dependem do tamanho da divergência das condições ecológicas pré e pós-conversão do uso da terra (Kessler et al. 2009). Existindo, assim, sistemas agrícolas que tem um grande impacto sobre a fauna e flora nativa, e outros tipos de sistemas agrícolas de baixo impacto, que podem ter um papel fundamental na conservação de espécies (Tscharntke et al. 2005), já que a paisagem agrícola de baixo impacto pode abrigar grande parte da biodiversidade do mundo (Pimentel et al. 1992) e a contribuição relativa de cada tipo de agrossistema para a conservação é pouco conhecida (Tscharntke et al. 2005).

Estudos recentes mostram que, no Cerrado, mudanças no uso da terra para sistemas simplificados e mais intensamente manejados, como plantações de soja ou milho, reduzem a riqueza de formigas (Frizzo \& Vasconcelos 2013; Pacheco et al. 2013). Todavia, agrossistemas menos intensivos, como pastagem, podem comportar uma riqueza de espécies semelhante à de áreas naturais (Frizzo \& Vasconcelos 2013), mostrando que áreas de produção agrícola podem ser utilizadas para a conservação de pelo menos parte da biodiversidade e/ou manejadas para reduzir a perda de espécies.

Porém o fato de que alguns tipos de agricultura abriguem muitas espécies nativas por si só não garante a conservação integral da biodiversidade. Introduzida por Whittaker (1960; 1972), a ideia de que o número de espécies de uma região (diversidade gama) é determinado pelo número de espécies em um local (diversidade alfa), mais a troca de espécies com outros locais (diversidade beta) é de suma importância para compreender como a diversidade está distribuída na paisagem e determinar ações conservacionistas.

Mais recentemente, Baselga (2010) criou uma metodologia para decompor a diversidade beta ou troca de espécies entre locais em dois processos distintos, chamado por 
ele de substituição de espécies ou perda de espécies. Basicamente isso retrata se a diversidade beta aumenta devido a uma troca de espécies entre os locais (por espécies diferentes) ou se o padrão de diversidade beta esta ligado a uma diferença no número de espécies devido ao aninhamento. Este nada mais é do que um padrão em que a comunidade com menos espécies é um subconjunto das comunidades com mais espécies (Almeida-Neto et al. 2008; Atmar \& Patterson 1993).

Por exemplo, no estudo de Pacheco e Vasconcelos (2012) no Cerrado, foi observado um aumento no número de espécies de formigas à medida que a estrutura da vegetação se tornava mais complexa, partindo de um gradiente de vereda até cerradão. Porém, a preservação apenas destes habitats complexos (com mais espécies localmente) está longe de garantir a conservação integral das espécies de formigas, já que 50\% da riqueza (diversidade beta) é explicada pela troca de espécies entre fitofisionomias do Cerrado e $25 \%$ por diferentes áreas de mesma fitofisionomia (Pacheco \& Vasconcelos 2012).

Porém, estes estudos são restritos a poucas áreas, e os padrões de diversidade, assim como a capacidade de manutenção destas espécies em diferentes tipos de ambientes modificados pelo homem, ainda não foram avaliados. Desse modo, este capítulo busca determinar como a conversão de áreas de vegetação nativa afeta a riqueza e composição de espécies de formigas de acordo com o tipo de uso da terra. Nesse caso, foram avaliados sistemas de plantio de soja, pastagem e agricultura orgânica, levando-se em conta os padrões de diversidade local, troca de espécies entre locais e diversidade regional. 


\section{Metodologia}

\section{Área de estudo}

As coletas foram realizadas de fevereiro a junho de 2013 e de fevereiro a maio de 2014, no Distrito Federal (abrangendo uma área de aproximadamente $5.800 \mathrm{Km}^{2}$, localizada centralmente a $15^{\circ} 47^{\prime} \mathrm{S}, 47^{\circ} 55^{\prime} \mathrm{O}$ ), em áreas como pastagem, plantio de soja e áreas de agricultura orgânica, além de áreas de vegetação nativa (Tabela 1.1). Ao todo foram amostradas 69 localidades, sendo: 14 plantios de soja convencional, 15 pastagens, 16 áreas de agricultura orgânica (destas, 14 são plantios de hortaliças e dois, AO-15 e AO-16, são plantios de soja orgânica) e 24 áreas de vegetação nativa. Das 24 áreas de vegetação nativa, optou-se por coletar nas três fitofisionomias mais comuns, as quais são: sete formações campestres, oito cerrado stricto sensu e nove formações florestais (Figura 1.1 e 1.2).

Segundo a classificação de Köppen (1948), o clima nessa região é do tipo Aw, apresentando forte sazonalidade com um verão chuvoso e o inverno seco. As temperaturas médias mensais podem variar de 22 a $27^{\circ} \mathrm{C}$ e a precipitação anual média é de $1.500 \mathrm{~mm}$ (Klink \& Machado 2005). Todas as localidades estão situadas no bioma Cerrado (para mais informações sobre a vegetação veja Oliveira-Filho \& Ratter 2002).

\section{Protocolo amostral}

Em cada uma das localidades foram amostrados três pontos distantes 20 metros entre si (chamados posteriormente como parcela amostral) (Figura 1.3 - A). Cada parcela amostral era composta por um grid de 12 armadilhas de queda do tipo pitfall, sendo dispostos em três fileiras com quatro armadilhas cada, e com espaçamento de dois metros entre si (Figura 1.3 B). As armadilhas de queda são copos plásticos de $200 \mathrm{ml}$, preenchidos até $1 / 3$ com água e 
detergente e ficaram em atividade no campo por 24 horas (Figura 1.3 - C). Ao todo foram instalados 12 pitfalls por parcela, 36 por localidade e 2.484 nas 69 localidades.

Após a coleta, o conteúdo de cada pitfall foi peneirado (em uma malha fina que impossibilita a perda de pequenos invertebrados) e armazenado em um recipiente com álcool $92,8 \%$, até ser finalmente triado. Todos os 12 pitfalls de cada parcela amostral foram reunidos em uma única amostra composta, para reduzir o tempo de triagem. Portanto, cada localidade possui ao todo três subamostras, e cada uma destas foi triada, de modo que para Formicidae foi realizada uma separação até o nível de espécie ou morfoespécie, sendo os gêneros separados seguindo a chave de Bolton et al. (2007) e Fernández (2003).

Para diminuir a possível influência do clima sobre a amostragem, as coletas foram realizadas apenas em dias sem a previsão de chuvas. Além disso, de duas a três localidades eram amostradas ao mesmo tempo (Tabela 1.1), diluindo possíveis efeitos climáticos entre as diferentes categorias analisadas.

\section{Análise dos dados}

A riqueza de espécies de formigas foi comparada entre ambientes de vegetação nativa e os diferentes sistemas agrícolas visando estimar a perda potencial de espécies devido à conversão de áreas nativas em sistemas agrícolas. Curvas de acúmulo de espécies e a estimativa de riqueza utilizando Jack 1 e Chao 2 foram calculadas para saber quanto do total esperado de espécies de formigas foi amostrado e se a riqueza por tipo de habitat é diferente entre os sistemas. Para todas essas análises foi utilizado o programa EstimateS 9.1.0 (Colwell 2013). Para saber se mudanças no uso da terra afetou de forma significativa a riqueza de formigas na localidade (diversidade alfa) foi utilizada uma Anova com teste a posteriore de Tukey (Gotelli \& Ellison 2011), sendo o fator habitat dividido em área de vegetação nativa, pastagem, soja ou agricultura orgânica. 
Para todas as análises de composição de espécies entre os habitats, foi utilizada uma matriz de presença e ausência por localidade (264 espécies x 69 localidades). A primeira análise a ser utilizada foi uma PERMANOVA, com 999 permutações, usando a função adonis do pacote vegan (Oksanen et al. 2015) no programa R (R Development Core Team, 2008). Esta foi utilizada por ser a análise mais robusta para dados não balanceados (Anderson \& Walsh 2013). Porém, como a análise de PERMANOVA não é capaz de definir quais habitats são diferentes entre si, foi realizada uma ordenação de NMDS (Non-metric multidimensional scaling) (Anderson 2001), utilizando a função metaMDS do pacote vegan (Oksanen et al. 2015), agrupando os pontos de coleta por suas similaridades. E, por fim, foi utilizada a análise de Valores Indicativos (IndVal) de Dufrene e Legendre (1997), que mostra quais espécies estão associadas e são indicativas de um determinado habitat com um valor de significância. Para esta última análise foi utilizada a função indval do pacote labdsv (Roberts 2016).

Além da diferença na ocorrência de espécies, foi realizada uma análise por grupo funcional, adaptando a classificação proposta por Frizzo et al. (2012) e Brandão et al. (2012). As espécies foram classificadas em: (1) Arborícola, espécies que nidificam estritamente na vegetação arbórea e arbustiva; (2) Attini, tribo que inclui todas as formigas que cultivam fungo; (3) Camponotini, tribo que inclui todas as espécies do gênero Camponotus; (4) Correição, grupo que contempla os gêneros Labidus, Neivamyrmex, Eciton e Nomamyrmex; (5) Especialista, grupo que contempla gêneros e algumas espécies com baixa frequência de ocorrência, geralmente apresentando aspectos ecológicos e/ou morfológicos incomuns (por ex: alimentar-se principalmente de sementes, possuir olhos muito grandes ou a ausência dos mesmos); (6) Generalista, grupo que contempla espécies com grande plasticidade ecológica e onívoras, sendo composto pela maioria das espécies do gênero Pheidole, Solenopsis, Brachymyrmex, além de espécies exóticas; (7) Generalista dominante, grupo composto por três espécies onívoras (Pheidole gertrudae (Forel, 1886), Pheidole sp.01 e Solenopsis 
saevissima (Smith, F., 1855)), que possuem a característica, devido ao grande recrutamento de indivíduos, de monopolizar o recurso encontrado frente aos demais competidores; (8) Oportunista, espécies do gênero Dorymyrmex e Linepthema, que forrageiam nos períodos mais quentes e que geralemente não monopolizam a fonte de alimento diante de competidores; (9) Predador grande, grupo que contempla a maioria das Ponerinaes e o gênero Ectatomma (para mais informações e a lista da classificação das espécies veja o Anexo I).

Após a classificação, foi avaliada qual a frequência de ocorrência de cada um dos grupos funcionais nos diferentes tipos de habitats. Para isso foi realizado um ánalise de modelos lineares generalizados, utilizando a função glm do R (R Development Core Team 2008). Nesta análise foi utilizado o número de registros por localidade, ou seja, foi contabilizado em quantas parcelas cada espécies foi registrada dentro de cada localidade.

Para avaliar se a riqueza de espécies de formigas é mais dependente da riqueza alfa ou beta, foi empregada uma análise de partição aditiva da diversidade em três níveis hierárquicos: parcela amostral, localidade e tipo de habitat. A soma da diversidade alfa (número médio de espécies na parcela amostral) mais cada um dos componentes da diversidade beta (número de espécies diferentes entre as localidades e tipos de habitats) deve ser igual à diversidade total de espécies de formigas coletada (ou seja, 264). Com a intenção avaliar se existe algum fator influenciando a diversidade de formigas, ou seja, alterando os valores de diversidade alfa e beta de forma significativamente diferente do que seria esperado ao acaso, foi criado um modelo nulo. Este modelo nulo foi feito atráves de 2.000 aleatorizações dos dados obtidos em campo, e a partir destas aleatorização é gerado um padrão que definimos como sendo ao acaso. Após esta etapa, comparamos o padrão encontrado em campo, com o padrão considerado ao acaso, caso a probabilidade do padrão encontrado em campo seja menor do que 5\% de chance de ter ocorrido devido ao acaso, consideramos este padrão como significativamente diferente, sendo este influenciado por 
algum fator (Veech et al. 2002). Para esse tipo de análise foi utilizada a função adipart, do pacote vegan (Oksanen et al. 2015).

Adicionalmente, diversidade beta $(\beta)$ foi decomposta em dois componentes que são processos ecológicos distintos: aninhamento ( $\beta$ nes) e troca de espécies ( $\beta$ sim) (Baselga et al. 2010). Simplificadamente, a diversidade $\beta$ foi calculada par a par entre as localidades com índice de Sorensen ( $\beta$ sor) e Simpson ( $\beta$ sim). $\beta$ sor é calculado levando-se em consideração a identidade das espécies e absorve a informação tanto da troca (turnover) como do aninhamento das espécies. Bsim é calculado a partir da probabilidade de se capturar determinada espécie em função do total de espécies (independente da identidade delas), calculando apenas a troca de espécies. Por isso, a diferença entre os índices calculados fornece o valor de diversidade beta devido ao aninhamento: $\beta$ nes $=\beta$ sor $-\beta \operatorname{sim}$ (Baselga et al . 2010).

Para essa análise foi utilizada a função beta.multi do pacote betapart (Baselga et al. 2015). Visando detectar diferenças entre agrossistemas e a vegetação nativa, foram feitas comparações entre os valores de $\beta$ sor, depois entre os de $\beta$ sim e, por fim, entre os de $\beta$ nes, através de um teste-t. A mesma comparação foi realizada entre os habitats (soja, pastagem, agricultura orgânica, campo, cerrado e mata), mas utilizando o teste não paramétrico de Kruskall-Wallis com um teste a posteriori usando a função posthoc.kruskal.nemenyi.test do pacote PMCMR (Pohlert 2016). Nesse teste de Kruskall-Wallis, os valores iguais dentro do banco de dados foram ranqueados aleatoriamente para evitar nós (ties) na análise. Em seguida, por meio da análise de Mantel (com o pacote vegan), entre a matriz de dissimilaridade gerada pela função beta.multi e uma matriz de distância entre as localidades, foi avaliada se a distância entre os pontos afeta a troca de espécies. Nos casos em que o resultado foi significativo, foi realizado uma correlação de Pearson para determinar a direção e a força da correlação. 
Tabela 1.1. Localidades amostradas no Distrito Federal com suas respectivas coordenadas, data de coleta e altitude em metros. Os termos entre parênteses referem-se à fitofisionomia nas áreas de vegetação nativa, sendo que "Campo" é referente a formações campestres, "Cerrado" a áreas de cerrado stricto sensu e "Mata" referente a formações florestais.

\begin{tabular}{|c|c|c|c|c|c|}
\hline Sistema & Localidade & Latitude & Longitude & Data & Altitude \\
\hline Agricultura orgânica & AO-01 & S $15^{\circ} 58^{\prime} 10.6^{\prime \prime}$ & W $047^{\circ} 29^{\prime} 41.8^{\prime \prime}$ & $03 / 04 / 2013$ & 890 \\
\hline Agricultura orgânica & AO-02 & $\mathrm{S} 15^{\circ} 45^{\prime} 44.2^{\prime \prime}$ & W $047^{\circ} 38^{\prime} 30.5^{\prime \prime}$ & 03/04/2013 & 948 \\
\hline Agricultura orgânica & AO-03 & S $15^{\circ} 33^{\prime} 55.6^{\prime \prime}$ & W $048^{\circ} 01^{\prime} 50.8^{\prime \prime}$ & $29 / 04 / 2013$ & 1250 \\
\hline Agricultura orgânica & AO-04 & S $15^{\circ} 49^{\prime} 30.1^{\prime \prime}$ & W $048^{\circ} 15^{\prime} 07.2^{\prime \prime}$ & $07 / 05 / 2013$ & 1.086 \\
\hline Agricultura orgânica & AO-05 & S $15^{\circ} 56^{\prime} 32.9^{\prime \prime}$ & W $048^{\circ} 08^{\prime} 24.9^{\prime \prime}$ & $07 / 05 / 2013$ & 989 \\
\hline Agricultura orgânica & AO-06 & S $15^{\circ} 49^{\prime} 42.7^{\prime \prime}$ & W $048^{\circ} 04^{\prime} 16.4^{\prime \prime}$ & $11 / 05 / 2013$ & 1.153 \\
\hline Agricultura orgânica & AO-07 & S $15^{\circ} 38^{\prime} 40.0^{\prime \prime}$ & W $048^{\circ} 09^{\prime} 58.5^{\prime \prime}$ & $11 / 05 / 2013$ & 1.134 \\
\hline Agricultura orgânica & AO-08 & S $15^{\circ} 56^{\prime} 06.8^{\prime \prime}$ & W $047^{\circ} 56^{\prime} 14.8^{\prime \prime}$ & $14 / 05 / 2013$ & 1.045 \\
\hline Agricultura orgânica & AO-09 & S $16^{\circ} 00^{\prime} 49.7^{\prime \prime}$ & W $047^{\circ} 44^{\prime} 45.8^{\prime \prime}$ & $23 / 05 / 2013$ & 1.018 \\
\hline Agricultura orgânica & AO-10 & S $15^{\circ} 58^{\prime} 14.7^{\prime \prime}$ & W $047^{\circ} 53^{\prime} 27.9^{\prime \prime}$ & $23 / 05 / 2013$ & 1.125 \\
\hline Agricultura orgânica & AO-11 & S 15³9'07.1" & W 04806'30.0" & 07/04/2014 & 1.209 \\
\hline Agricultura orgânica & AO-12 & S $15^{\circ} 55^{\prime} 36.5^{\prime \prime}$ & W $047^{\circ} 46^{\prime} 02.5^{\prime \prime}$ & $12 / 05 / 2014$ & 923 \\
\hline Agricultura orgânica & AO-13 & S $15^{\circ} 39^{\prime} 02.0^{\prime \prime}$ & W $048^{\circ} 12^{\prime} 03.3^{\prime \prime}$ & $15 / 05 / 2014$ & 1.105 \\
\hline Agricultura orgânica & AO-14 & S $15^{\circ} 36^{\prime} 44.5^{\prime \prime}$ & W $048^{\circ} 04^{\prime} 42.7^{\prime \prime}$ & $19 / 05 / 2014$ & 1.257 \\
\hline Agricultura orgânica & AO-15 & S $15^{\circ} 57^{\prime} 55.3^{\prime \prime}$ & W $047^{\circ} 30^{\prime} 08.0^{\prime \prime}$ & $14 / 03 / 2013$ & 895 \\
\hline Agricultura orgânica & AO-16 & S $15^{\circ} 40^{\prime} 03.8^{\prime \prime}$ & W $048^{\circ} 10^{\prime} 00.5^{\prime \prime}$ & $19 / 03 / 2013$ & 1.219 \\
\hline Pastagem & P-01 & S $15^{\circ} 42^{\prime} 00.9^{\prime \prime}$ & W $047^{\circ} 55^{\prime} 02.9^{\prime \prime}$ & $11 / 03 / 2013$ & 1.053 \\
\hline Pastagem & P-02 & S $15^{\circ} 58^{\prime} 27.9^{\prime \prime}$ & W $047^{\circ} 29^{\prime} 50.1^{\prime \prime}$ & 03/04/2013 & 879 \\
\hline Pastagem & P-03 & S $15^{\circ} 35^{\prime} 51.5^{\prime \prime}$ & W $047^{\circ} 43^{\prime} 20.2^{\prime \prime}$ & $17 / 04 / 2013$ & 1.002 \\
\hline Pastagem & P-04 & S $15^{\circ} 35^{\prime} 59.3^{\prime \prime}$ & W $047^{\circ} 36^{\prime} 32.6^{\prime \prime}$ & $17 / 04 / 2013$ & 1046 \\
\hline Pastagem & P-05 & S $15^{\circ} 33^{\prime} 53.7^{\prime \prime}$ & W $047^{\circ} 31^{\prime} 16.8^{\prime \prime}$ & $17 / 04 / 2013$ & 1.102 \\
\hline Pastagem & P-06 & S $15^{\circ} 47^{\prime} 45.6^{\prime \prime}$ & W $047^{\circ} 38^{\prime} 59.5^{\prime \prime}$ & $22 / 04 / 2013$ & 1031 \\
\hline Pastagem & P-07 & S $15^{\circ} 52^{\prime} 58.4^{\prime \prime}$ & W $047^{\circ} 34^{\prime} 55.1^{\prime \prime}$ & $22 / 04 / 2013$ & 1.001 \\
\hline Pastagem & P-08 & S $15^{\circ} 56^{\prime} 28.0^{\prime \prime}$ & W $047^{\circ} 54^{\prime} 52.8^{\prime \prime}$ & $14 / 05 / 2013$ & 1.010 \\
\hline Pastagem & P-09 & S $15^{\circ} 57^{\prime} 05.1^{\prime \prime}$ & W $048^{\circ} 08^{\prime} 17.1^{\prime \prime}$ & $20 / 05 / 2013$ & 987 \\
\hline Pastagem & P-10 & S $15^{\circ} 49^{\prime} 37.9^{\prime \prime}$ & W $048^{\circ} 14^{\prime} 56.6^{\prime \prime}$ & $20 / 05 / 2013$ & 1.104 \\
\hline Pastagem & P-11 & S $15^{\circ} 39^{\prime} 06.4^{\prime \prime}$ & W $048^{\circ} 06^{\prime} 09.1^{\prime \prime}$ & $07 / 04 / 2014$ & 1.196 \\
\hline Pastagem & P-12 & S $15^{\circ} 55^{\prime} 17.3^{\prime \prime}$ & W $048^{\circ} 02^{\prime} 04.4^{\prime \prime}$ & $23 / 04 / 2014$ & 1.213 \\
\hline Pastagem & P-13 & S $15^{\circ} 39^{\prime} 16.1^{\prime \prime}$ & W $047^{\circ} 42^{\prime} 10.6^{\prime \prime}$ & $01 / 05 / 2014$ & 967 \\
\hline Pastagem & P-14 & S $15^{\circ} 55^{\prime} 42.0^{\prime \prime}$ & W $047^{\circ} 44^{\prime} 50.1^{\prime \prime}$ & $12 / 05 / 2014$ & 959 \\
\hline Pastagem & P-15 & S $15^{\circ} 36^{\prime} 32.0^{\prime \prime}$ & W $048^{\circ} 09^{\prime} 48.5^{\prime \prime}$ & $15 / 05 / 2014$ & 1.254 \\
\hline Plantação de soja & S-01 & S $15^{\circ} 34^{\prime} 26.0^{\prime \prime}$ & W $047^{\circ} 32^{\prime} 48.6^{\prime \prime}$ & $07 / 02 / 2013$ & 1.159 \\
\hline Plantação de soja & S-02 & S $15^{\circ} 40^{\prime} 52.0^{\prime \prime}$ & W $047^{\circ} 20^{\prime} 46.4^{\prime \prime}$ & $10 / 02 / 2013$ & 928 \\
\hline Plantação de soja & S-03 & S $15^{\circ} 42^{\prime} 25.8^{\prime \prime}$ & W $047^{\circ} 27^{\prime} 38.6^{\prime \prime}$ & $10 / 02 / 2013$ & 998 \\
\hline Plantação de soja & S-04 & S $15^{\circ} 43^{\prime} 06.9^{\prime \prime}$ & W $047^{\circ} 35^{\prime} 24.8^{\prime \prime}$ & $10 / 02 / 2013$ & 1.175 \\
\hline Plantação de soja & S-05 & S $15^{\circ} 58^{\prime} 32.8^{\prime \prime}$ & W $047^{\circ} 34^{\prime} 33.2^{\prime \prime}$ & $14 / 02 / 2013$ & 1.041 \\
\hline Plantação de soja & S-06 & S $15^{\circ} 58^{\prime} 10.6^{\prime \prime}$ & W $047^{\circ} 51^{\prime} 39.3^{\prime \prime}$ & $22 / 02 / 2013$ & 1.098 \\
\hline Plantação de soja & S-07 & S $15^{\circ} 47^{\prime} 18.5^{\prime \prime}$ & W $047^{\circ} 38^{\prime} 21.6^{\prime \prime}$ & $14 / 02 / 2013$ & 1.002 \\
\hline Plantação de soja & S-08 & S $15^{\circ} 46^{\prime} 37.8^{\prime \prime}$ & W $047^{\circ} 23^{\prime} 17.8^{\prime \prime}$ & $26 / 02 / 2013$ & 946 \\
\hline Plantação de soja & S-09 & S $15^{\circ} 55^{\prime} 13.2^{\prime \prime}$ & W $047^{\circ} 22^{\prime} 57.9^{\prime \prime}$ & $01 / 03 / 2013$ & 879 \\
\hline
\end{tabular}

Continua... 


\begin{tabular}{|c|c|c|c|c|c|}
\hline Sistema & Localidade & Latitude & Longitude & Data & Altitude \\
\hline Plantação de soja & $\mathrm{S}-10$ & S $16^{\circ} 00^{\prime} 37.6^{\prime \prime}$ & W $047^{\circ} 27^{\prime} 36.3^{\prime \prime}$ & $01 / 03 / 2013$ & 984 \\
\hline Plantação de soja & $\mathrm{s}-11$ & S $15^{\circ} 46^{\prime} 40.2^{\prime \prime}$ & W 047 33' 55.9" & 03/02/2014 & 946 \\
\hline Plantação de soja & $\mathrm{S}-12$ & S $15^{\circ} 47^{\prime} 58.1^{\prime \prime}$ & W $047^{\circ} 32^{\prime} 54.5^{\prime \prime}$ & 03/02/2014 & 988 \\
\hline Plantação de soja & S-13 & S $15^{\circ} 36^{\prime} 28.3^{\prime \prime}$ & W $047^{\circ} 44^{\prime} 38.7^{\prime \prime}$ & $14 / 04 / 2014$ & 1.121 \\
\hline Plantação de soja & S-14 & S $15^{\circ} 54^{\prime} 48.1^{\prime \prime}$ & W $048^{\circ} 02^{\prime} 20.7^{\prime \prime}$ & $23 / 04 / 2014$ & 1.226 \\
\hline Vegetação nativa (Campo) & VN-01 & S $15^{\circ} 58^{\prime} 35.0^{\prime \prime}$ & W $047^{\circ} 56^{\prime} 55.9^{\prime \prime}$ & $02 / 05 / 2013$ & 1.174 \\
\hline Vegetação nativa (Mata) & VN-02 & S $15^{\circ} 55^{\prime} 53.7^{\prime \prime}$ & W $047^{\circ} 54^{\prime} 09.9^{\prime \prime}$ & $02 / 05 / 2013$ & 1.062 \\
\hline Vegetação nativa (Cerrado) & VN-03 & S $15^{\circ} 57^{\prime} 55.9^{\prime \prime}$ & W $047^{\circ} 55^{\prime} 41.7^{\prime \prime}$ & $02 / 05 / 2013$ & 1.153 \\
\hline Vegetação nativa (Cerrado) & VN-04 & S $15^{\circ} 43^{\prime} 49.4^{\prime \prime}$ & W $047^{\circ} 57^{\prime} 41.6^{\prime \prime}$ & 29/05/2013 & 1.108 \\
\hline Vegetação nativa (Mata) & VN-05 & S $15^{\circ} 43^{\prime} 59.6^{\prime \prime}$ & W $048^{\circ} 00^{\prime} 53.8^{\prime \prime}$ & $29 / 05 / 2013$ & 1.101 \\
\hline Vegetação nativa (Campo) & VN-06 & S $15^{\circ} 39^{\prime} 37.2^{\prime \prime}$ & W $047^{\circ} 58^{\prime} 33.9^{\prime \prime}$ & $05 / 06 / 2013$ & 1.112 \\
\hline Vegetação nativa (Cerrado) & VN-07 & S $15^{\circ} 38^{\prime} 24.1^{\prime \prime}$ & W $048^{\circ} 01^{\prime} 32.5^{\prime \prime}$ & $05 / 06 / 2013$ & 1.238 \\
\hline Vegetação nativa (Campo) & VN-08 & S $15^{\circ} 32^{\prime} 15.4^{\prime \prime}$ & W $047^{\circ} 36^{\prime} 45.6^{\prime \prime}$ & $10 / 06 / 2013$ & 1.038 \\
\hline Vegetação nativa (Cerrado) & VN-09 & S $15^{\circ} 35^{\prime} 01.1^{\prime \prime}$ & W $047^{\circ} 36^{\prime} 51.2^{\prime \prime}$ & $10 / 06 / 2013$ & 1.041 \\
\hline Vegetação nativa (Mata) & VN-10 & S $15^{\circ} 34^{\prime} 40.3^{\prime \prime}$ & W $047^{\circ} 41^{\prime} 55.7^{\prime \prime}$ & $10 / 06 / 2013$ & 982 \\
\hline Vegetação nativa (Campo) & VN-11 & S $15^{\circ} 56^{\prime} 46.1^{\prime \prime}$ & W $048^{\circ} 09^{\prime} 11.4^{\prime \prime}$ & $13 / 06 / 2013$ & 1.070 \\
\hline Vegetação nativa (Mata) & VN-12 & S $15^{\circ} 56^{\prime} 35.1^{\prime \prime}$ & W $048^{\circ} 08^{\prime} 25.6^{\prime \prime}$ & $13 / 06 / 2013$ & 984 \\
\hline Vegetação nativa (Mata) & VN-13 & S $15^{\circ} 53^{\prime} 15.2^{\prime \prime}$ & W $047^{\circ} 50^{\prime} 28.7^{\prime \prime}$ & $12 / 02 / 2014$ & 1088 \\
\hline Vegetação nativa (Campo) & VN-14 & S $15^{\circ} 52^{\prime} 37.3^{\prime \prime}$ & W $047^{\circ} 49^{\prime} 31.9^{\prime \prime}$ & $12 / 02 / 2014$ & 1104 \\
\hline Vegetação nativa (Cerrado) & VN-15 & S $15^{\circ} 53^{\prime} 11.1^{\prime \prime}$ & W $047^{\circ} 49^{\prime} 37.4^{\prime \prime}$ & $12 / 02 / 2014$ & 1125 \\
\hline Vegetação nativa (Cerrado) & VN-16 & S $15^{\circ} 55^{\prime} 40.5^{\prime \prime}$ & W $048^{\circ} 01^{\prime} 38.1^{\prime \prime}$ & $17 / 03 / 2014$ & 1185 \\
\hline Vegetação nativa (Mata) & VN-17 & S $15^{\circ} 54^{\prime} 24.1^{\prime \prime}$ & W $048^{\circ} 00^{\prime} 40.3^{\prime \prime}$ & $17 / 03 / 2014$ & 1036 \\
\hline Vegetação nativa (Campo) & VN-18 & S $15^{\circ} 36^{\prime} 18.1^{\prime \prime}$ & W $047^{\circ} 44^{\prime} 58.5^{\prime \prime}$ & $14 / 04 / 2014$ & 1153 \\
\hline Vegetação nativa (Cerrado) & VN-19 & S $15^{\circ} 36^{\prime} 38.4^{\prime \prime}$ & W $047^{\circ} 43^{\prime} 43.4^{\prime \prime}$ & $17 / 04 / 2014$ & 1065 \\
\hline Vegetação nativa (Mata) & VN-20 & S $15^{\circ} 36^{\prime} 28.6^{\prime \prime}$ & W $047^{\circ} 42^{\prime} 49.4^{\prime \prime}$ & $17 / 04 / 2014$ & 1000 \\
\hline Vegetação nativa (Campo) & VN-21 & S $15^{\circ} 39^{\prime} 11.0^{\prime \prime}$ & W $047^{\circ} 42^{\prime} 48.2^{\prime \prime}$ & $28 / 04 / 2014$ & 962 \\
\hline Vegetação nativa (Cerrado) & VN-22 & S $15^{\circ} 39^{\prime} 43.8^{\prime \prime}$ & W $047^{\circ} 42^{\prime} 22.4^{\prime \prime}$ & $28 / 04 / 2014$ & 955 \\
\hline Vegetação nativa (Mata) & VN-23 & S $15^{\circ} 39^{\prime} 33.0^{\prime \prime}$ & W $047^{\circ} 41^{\prime} 18.1^{\prime \prime}$ & $01 / 05 / 2014$ & 929 \\
\hline Vegetação nativa (Mata) & VN-24 & S $15^{\circ} 33^{\prime} 49.7^{\prime \prime}$ & W $047^{\circ} 32^{\prime} 25.4^{\prime \prime}$ & $07 / 02 / 2013$ & 1.149 \\
\hline
\end{tabular}




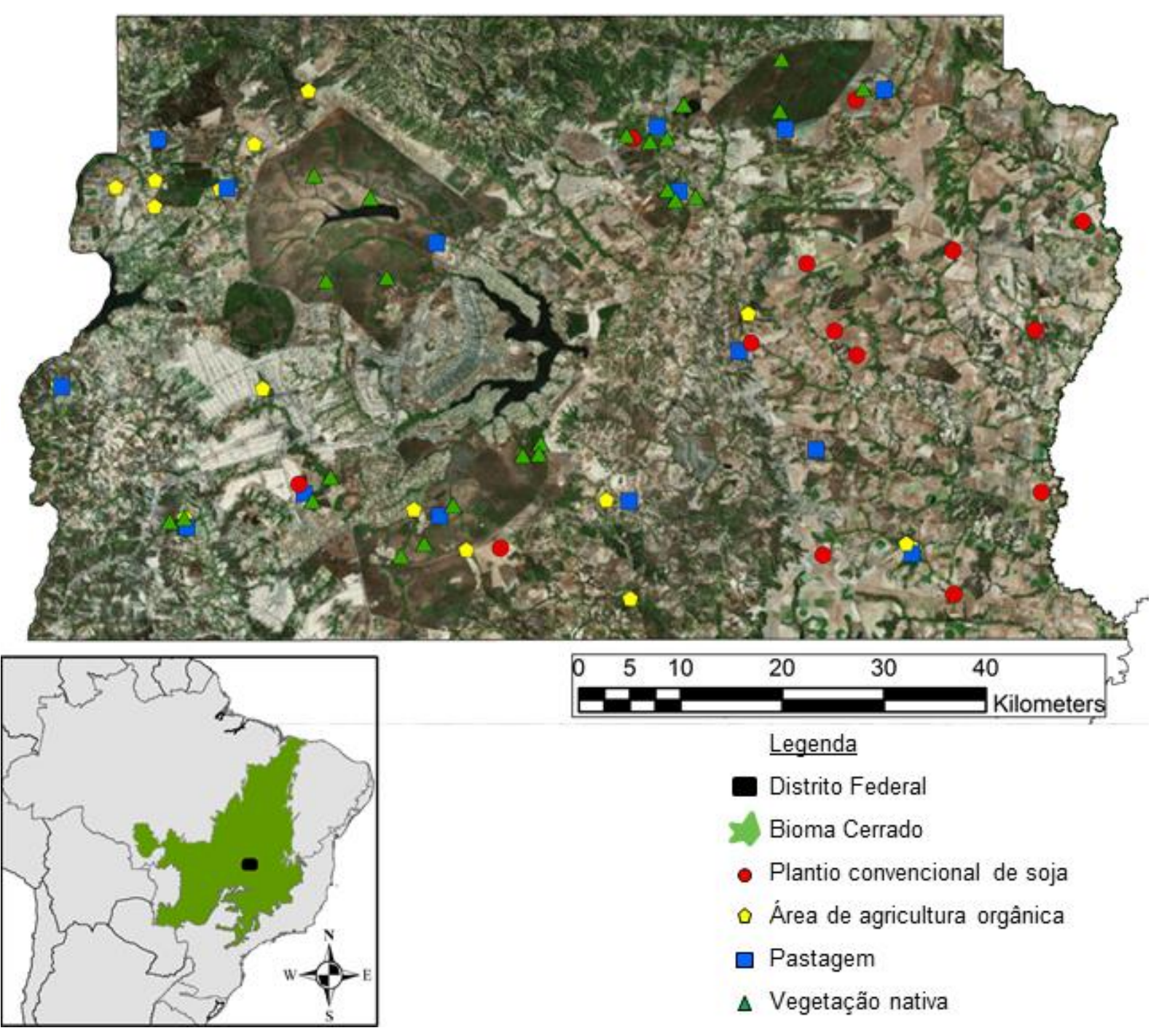

Figura 1.1. Mapa das 69 localidades amostradas dentro do Distrito Federal no ano de 2013 e 2014. 

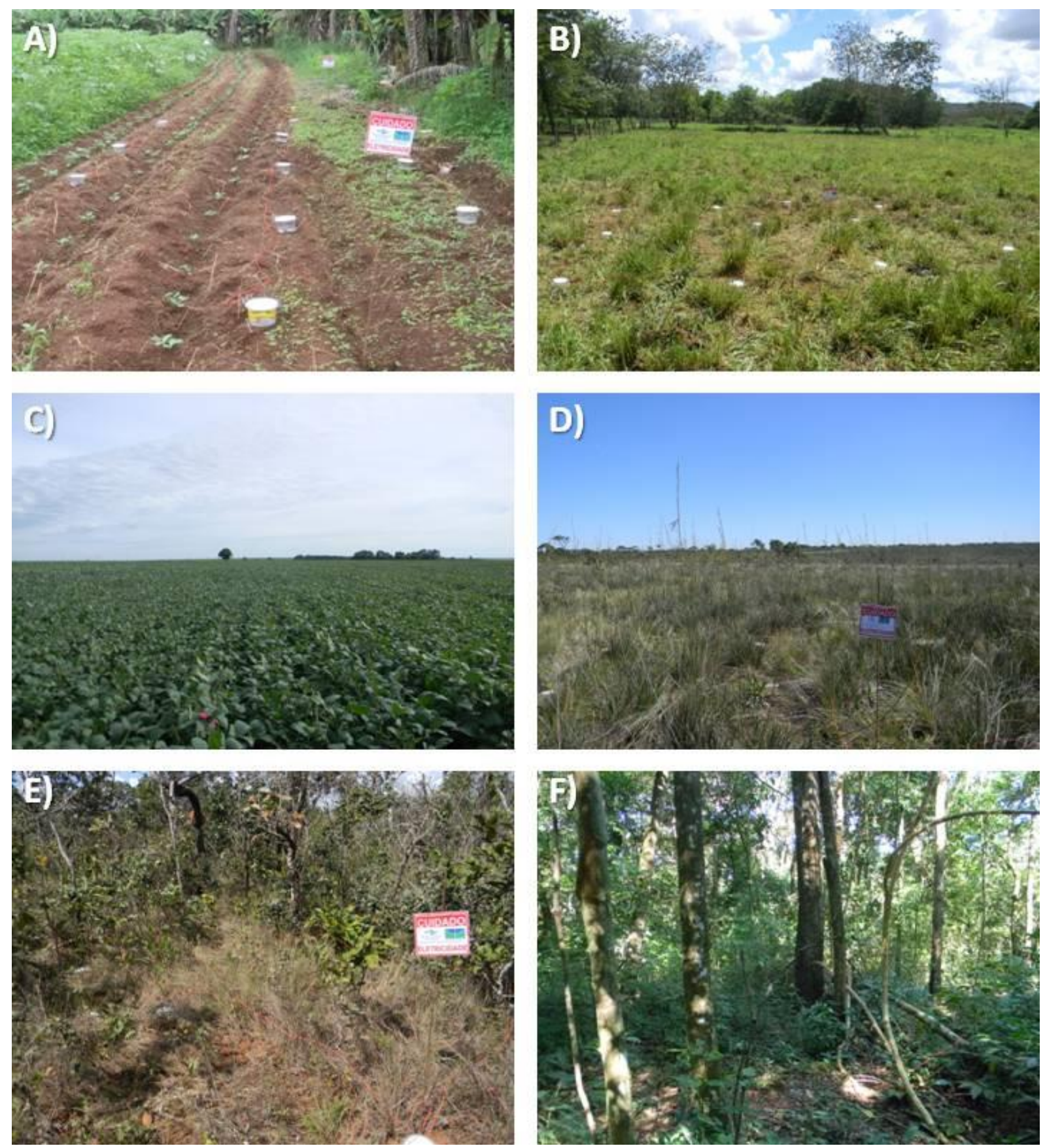

Figura 1.2. Fotografia das áreas de coleta no Distrito Federal no ano de 2013 e 2014. A) Área de agricultura orgânica. B) Área de pastagem. C) Área de plantio de soja. Fotografias das áreas de vegetação nativa: D) área de formação campestre, E) área de cerrado stricto sensu e F) área de formação florestal. 

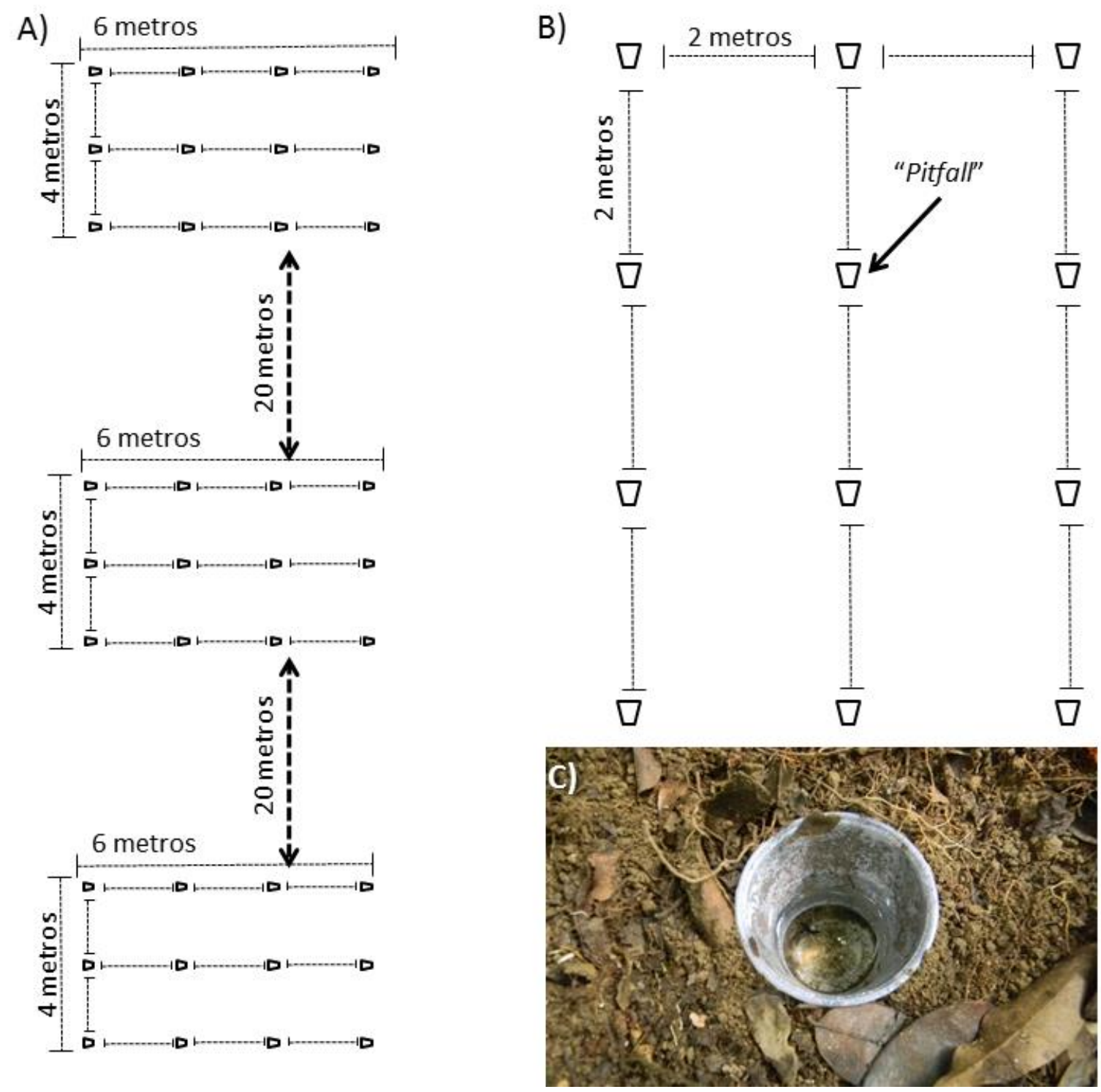

Figura 1.3. Metodologia empregada para a coleta de formigas. A) Distribuição das parcelas amostrais em cada localidade. B) Distribuição dos pitfalls em cada parcela amostral. C) Fotografia de um pitfall no campo. 


\section{Resultados}

Foram coletadas ao todo 264 espécies, o que representa de $74 \%$ a $78 \%$ das espécies estimadas na superfície do solo para a região do Distrito Federal, utilizando os estimadores de diversidade Jack 1 (342 espécies) e Chao 2 (354 espécies). Registrou-se 3.965 ocorrências de formigas, sendo estas distribuídas em 58 gêneros e oito subfamílias (Anexo II). Myrmicinae foi a subfamília que apresentou maior riqueza, com 151 espécies de formigas, e o gênero Pheidole o mais diverso, com 41 espécies e mais três complexos de espécies (ocorrendo em 98\% das localidades). A subfamília Formicinae foi a segunda mais diversa, com 48 espécies, e que apresenta o segundo gênero mais diverso, Camponotus, com 29 espécies. Os gêneros Solenopsis, Crematogaster, Brachymyrmex e Trachymyrmex também se destacam por ter entre 17 e 10 espécies, todos pertencentes à subfamília Myrmicinae, com exceção de Brachymyrmex, da subfamília Formicinae.

Comparando a diversidade rarefeita de formigas, entre a vegetação nativa e sistemas de produção agropecuários, nota-se que há uma queda na riqueza de formigas de $39 \%$ para pastagens, 44\% para áreas de agricultura orgânica e $83 \%$ em áreas de monocultura de soja (Figura 1.4). Esses valores são semelhantes quando utilizado o estimador de riqueza Jack 1, de $40 \%$ para pastagem, $47 \%$ para áreas de agricultura orgânica e $82 \%$ para o cultivo de soja (Figura 1.5).

A análise da riqueza local, que corresponde ao número médio de espécies coletadas em cada uma das 69 localidades, também revela que há uma diferença entre as áreas de vegetação nativa e os sistemas agrícolas. As áreas de soja são significativamente mais pobres em espécies do que os sistemas orgânicos e pastagens $\left(F_{3,65}=66,96 \mathrm{p}<0,001\right)$, que apresentam o mesmo número de espécies entre si (Figura 1.6). Já as áreas de vegetação nativa são mais ricas em espécies do que todas as áreas manejadas. 
Por fim, detectamos que tanto a riqueza como a composição de espécies nas áreas de vegetação nativa são influenciadas pela ocorrência de espécies únicas e raras (Figura 1.7, 1.8 e 1.9). Consideramos como espécies raras aquelas que ocorreram apenas uma vez em um determinado tipo de sistema agrícola ou fitofisionomia nativa, e como espécies únicas aquelas que ocorreram apenas uma vez em todo o estudo. As espécies raras e únicas corresponderam a aproximadamente $30 \%$ das espécies que ocorrem tanto em agrossistemas como em áreas de vegetação nativa (Figura 1.7). Porém as áreas de vegetação nativa apresentam proporcionalmente muito mais espécies raras e únicas que os sistemas agrícolas (Figura 1.8). É interessante notar também que, foram amostradas espécies com alta frequência de ocorrência, capazes de sobreviver tanto em áreas de vegetação nativa, como nos agrossistemas, mas há medida que as espécies diminuem em frequência elas demonstram uma preferencia ou exclusividade por determinado tipo de habitat (figura 1.9).

A análise PERMANOVA indica que há uma diferença significativa na composição de espécies $\left(\mathrm{F}_{3,68}=10,697\right.$ p <0,001). A ordenação (Figura 1.10) mostra que, além da riqueza, há também diferenças entre a composição de espécies dos sistemas de vegetação nativa e a dos sistemas agropecuários. Fica, então, visível um gradiente de mudança, na qual monocultura de soja e formações florestais são comunidades singulares (diferentes de todas aos outras). Além destes, mais dois grupos se formam, cerrado e campo, duas fitofisionomias naturais muito mais similares entre si do que entre as áreas de mata. Pastagem e áreas de agricultura orgânica também possuem uma comunidade relativamente similar.

Uma segunda evidência da alteração no padrão de distribuição e abundância das espécies está nos resultados obtidos na análise com o Indval, que detectou 91 espécies com valores de indicação significativos, variando de $1 \%$ até $75 \%$ (Tabela 1.2). Por exemplo: Pheidole sp.04 tem 59\% de chance de ocorrer em uma área de monocultura de soja, Pheidole sp.35 tem $61 \%$ de chance de ocorrer em áreas de agricultura orgânica e Dorymyrmex cf. 
brunneus (Forel, 1908) tem $46 \%$ de chance de ocorrer em pastagens. É importante notar também que o número de espécies indicadoras é quase três vezes e meia maior nas fitofisionomias nativas comparativamente às áreas agrícolas.

Fica evidente também que os grupos funcionais são afetados pela conversão de áreas nativas em sistemas agrícolas ou pelo tipo de uso da terra (Figura 1.11). Dos diversos grupos funcionais, Correição foi o único grupo que não mostrou diferença significativa de ocorrência entre os diferentes tipos de habitats, porém este é um grupo nômade e relativamente raro. $\mathrm{O}$ grupo das Generalistas Dominantes foi o único grupo que aumentou em número de registros nas áreas de agricultura orgânica e pastagem, comparativamente às áreas de vegetação nativa. Para todos os demais grupos, as áreas de vegetação nativa possuem significativamente mais registros que os sistemas agrícolas, com exceção das Generalistas e Oportunistas.

Realizando a análise de partição aditiva de diversidade (Figura 1.12) com todos os sistemas e fitofisionomias hierarquizados, observou-se que a riqueza alfa ( $\alpha 1)$ é maior que o esperado (5,8\%). Já a troca de espécies entre as parcelas de cada localidade é $29 \%$ menor do que o esperado, assim como a troca de espécies entre localidades dentro do mesmo sistema ou fitofisionomia ( $14 \%$ menor que o esperado). A troca de espécies entre os diferentes sistemas e fitofisionomias ( $\beta 3$ ) passa, então, a ter a maior importância para o padrão de diversidade encontrado, sendo $15,9 \%$ maior que o esperado ao acaso.

Análises de partição aditiva da diversidade também foram feitas em separado para cada sistema ou fitofisionomia (Anexo III). Entretanto, independentemente do sistema ou fitofisionomia, os padrões de partição aditiva da diversidade são semelhantes entre si. Todos foram diferentes do esperado ao acaso, de modo que, quando se analisa cada sistema ou fitofisionomia em separado, a diversidade alfa (riqueza dentro de cada parcela) é em torno de 2,3\% mais alta que o esperado. Já a diversidade beta1, ou troca de espécie entre as parcelas de 
pitfalls dentro de cada localidade, é $4,1 \%$ menor que o esperado, mostrando homogeneidade nesta escala. Enquanto a troca de espécies entre localidades é 4,1\% maior que o esperado.

Por outro lado, a diversidade beta ( $\beta$ sor) pode estar agrupando dois processos distintos: a troca de espécies (turnover) e/ou o aninhamento (perda de espécies). A análise de diversidade multiplicativa separou estes dois fatores e demostra que a maior parte da diversidade é devida à troca de espécies ( $\beta$ sim), tendo pouca influência do aninhamento ( $\beta$ nes) (Figura 1.13). Porém, o aninhamento para os agrossistemas é o triplo do encontrado em áreas nativas, o que demonstra maior homogeneização nas áreas agrícolas. Além disso, a análise de Mantel entre o nível de dissimilaridade e a distância entre os pontos, demonstra que apenas para os agrossistemas quanto maior a distância maior a troca de espécies (Figura 1.14). 


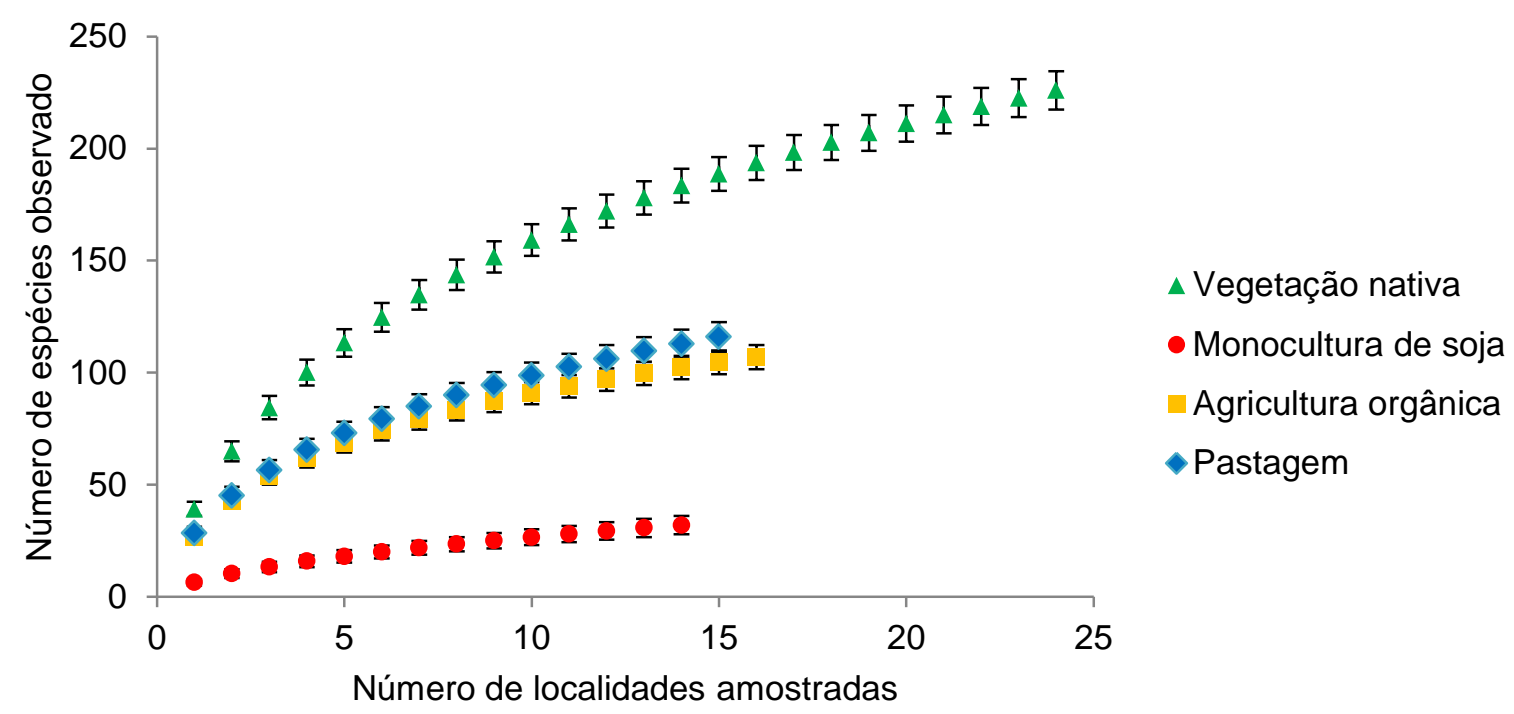

Figura 1.4. Número acumulado de espécies de formigas por localidades amostradas com o respectivo desvio padrão baseadas em coletadas realizadas em 2013 e 2014 no Distrito Federal com piffall.

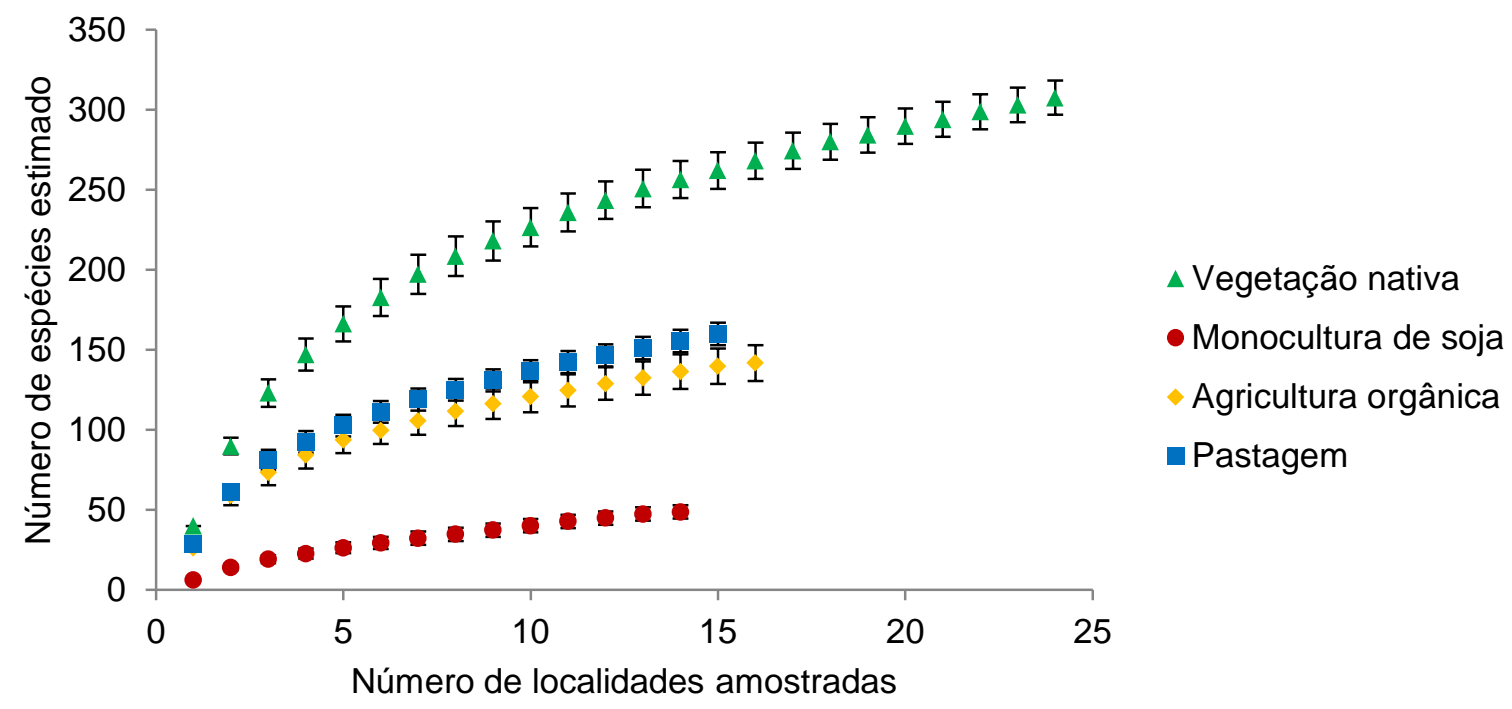

Figura 1.5. Número estimado de espécies de formigas por número de localidades amostradas utilizando o estimador Jack 1 com o respectivo desvio padrão baseado em coletas realizadas em 2013 e 2014 no Distrito Federal com pitfall. 


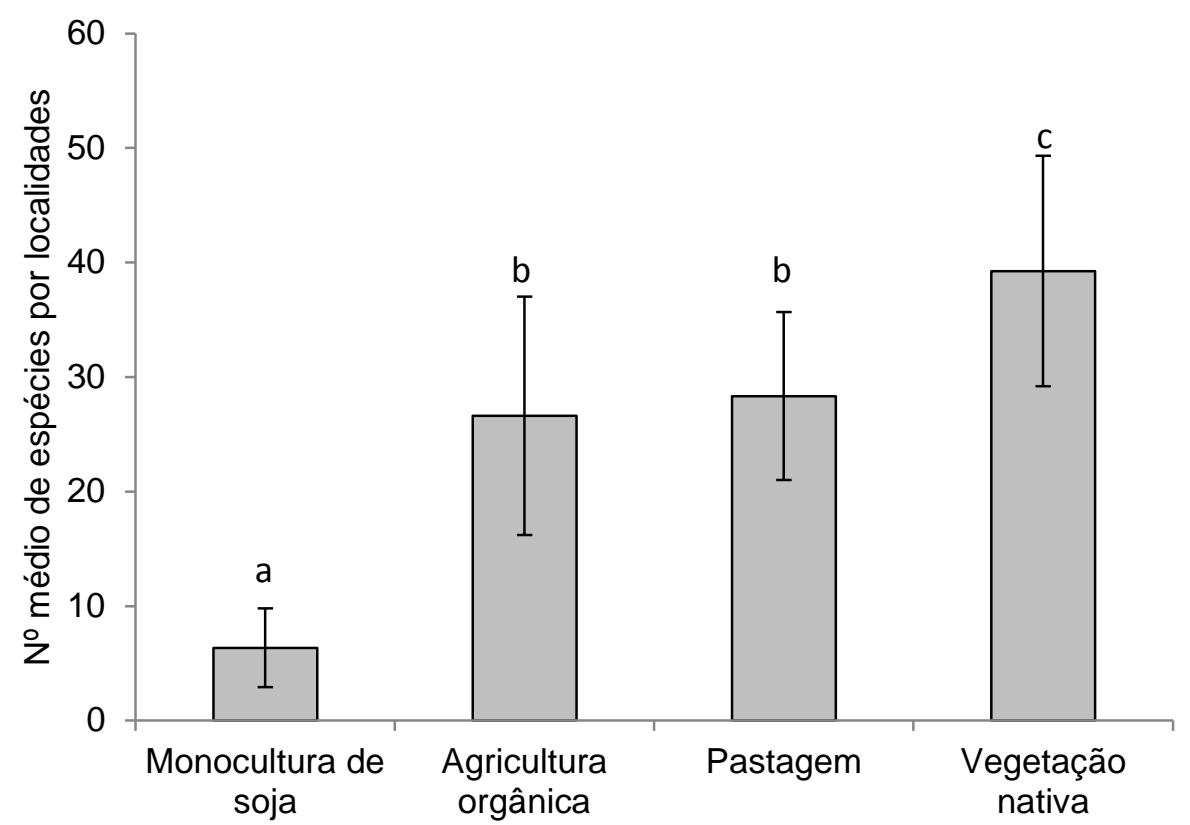

Figura 1.6. Número médio de espécies de formigas por localidade, coletados no Distrito Federal em 2013 e 2014 com pitfall nos diferentes tipos de habitat. As barras representam o desvio padrão e as letras diferentes significam diferenças significativas $(\mathrm{p}<0,05)$.

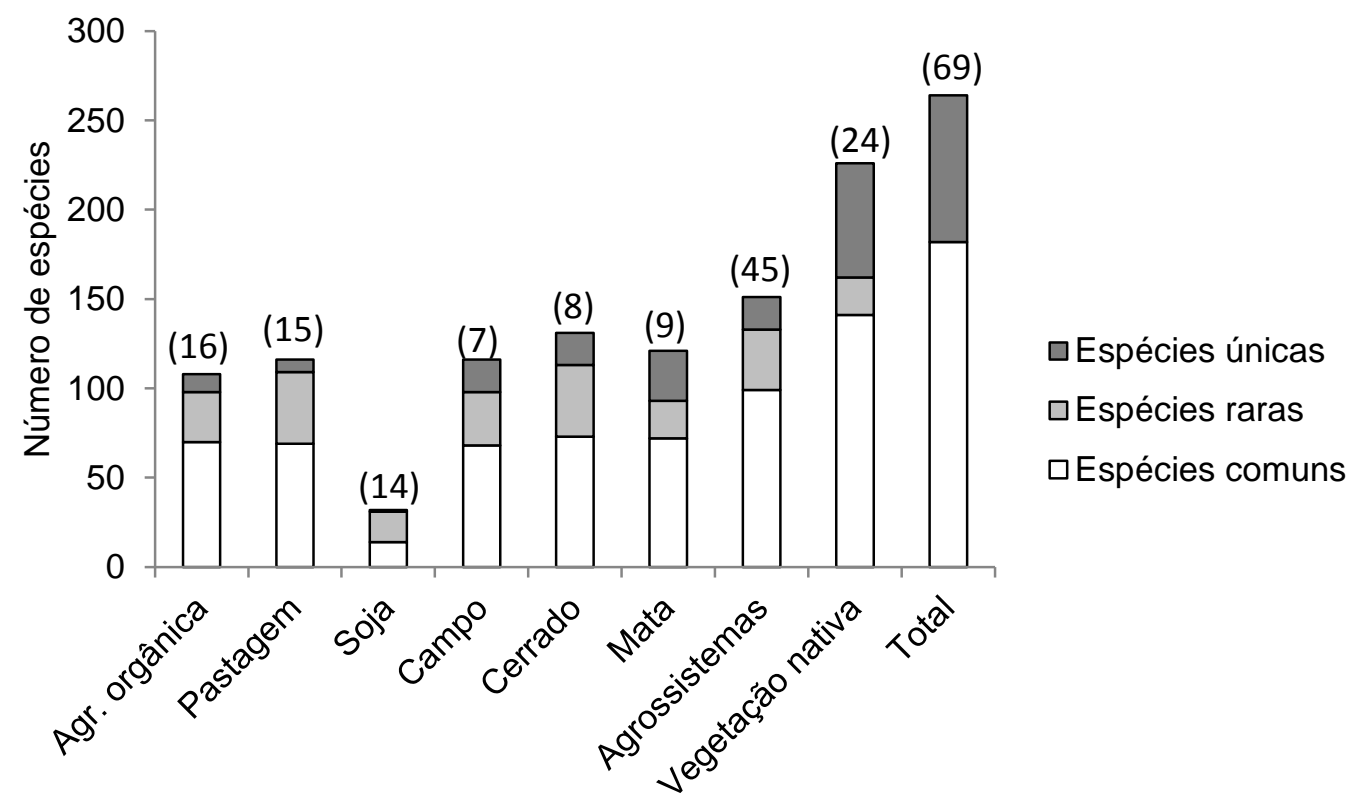

Figura 1.7. Ocorrência de espécies comuns, raras e únicas coletadas no Distrito Federal em 2013 e 2014 com armadilhas de queda (pitfall) nos diferentes tipos de habitat. Acima das barras e entre parênteses esta o número de localidades amostradas. Em branco são as espécies consideradas comuns, ou seja, que ocorreram mais de uma vez dentro do habitat. Em cinza claro, as espécies raras, que ocorreram uma única vez no habitat, mas ocorrem em outros habitats. Em cinza escuro, espécies que ocorreram uma única vez em todo o estudo. 


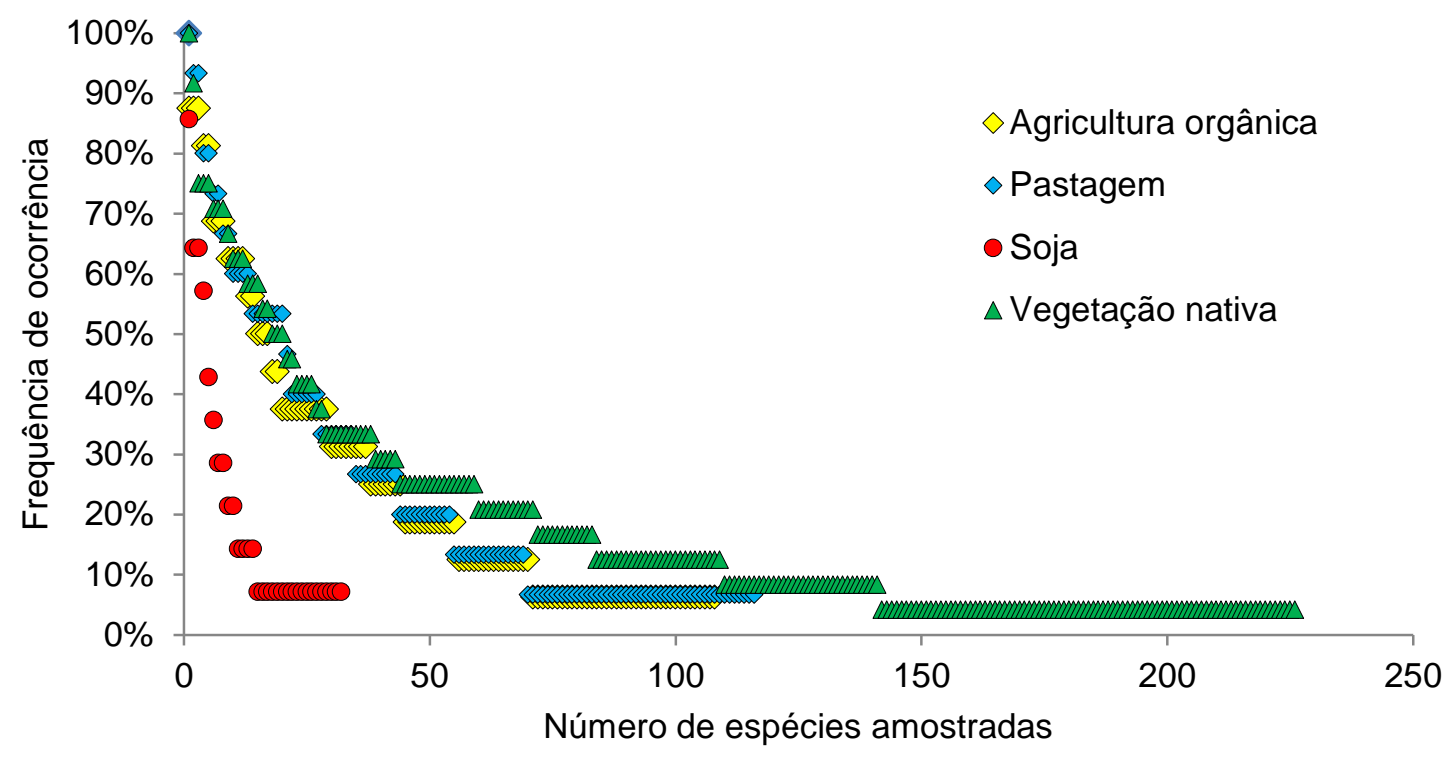

Figura 1.8. Frequência de ocorrência das espécies coletadas no Distrito Federal em 2013 e 2014 com armadilhas de queda (pitfall) nos diferentes tipos de habitat. As espécies foram ordenadas de forma decrescente, de acordo com a sua frequência de ocorrência nas 69 localidades amostradas. 


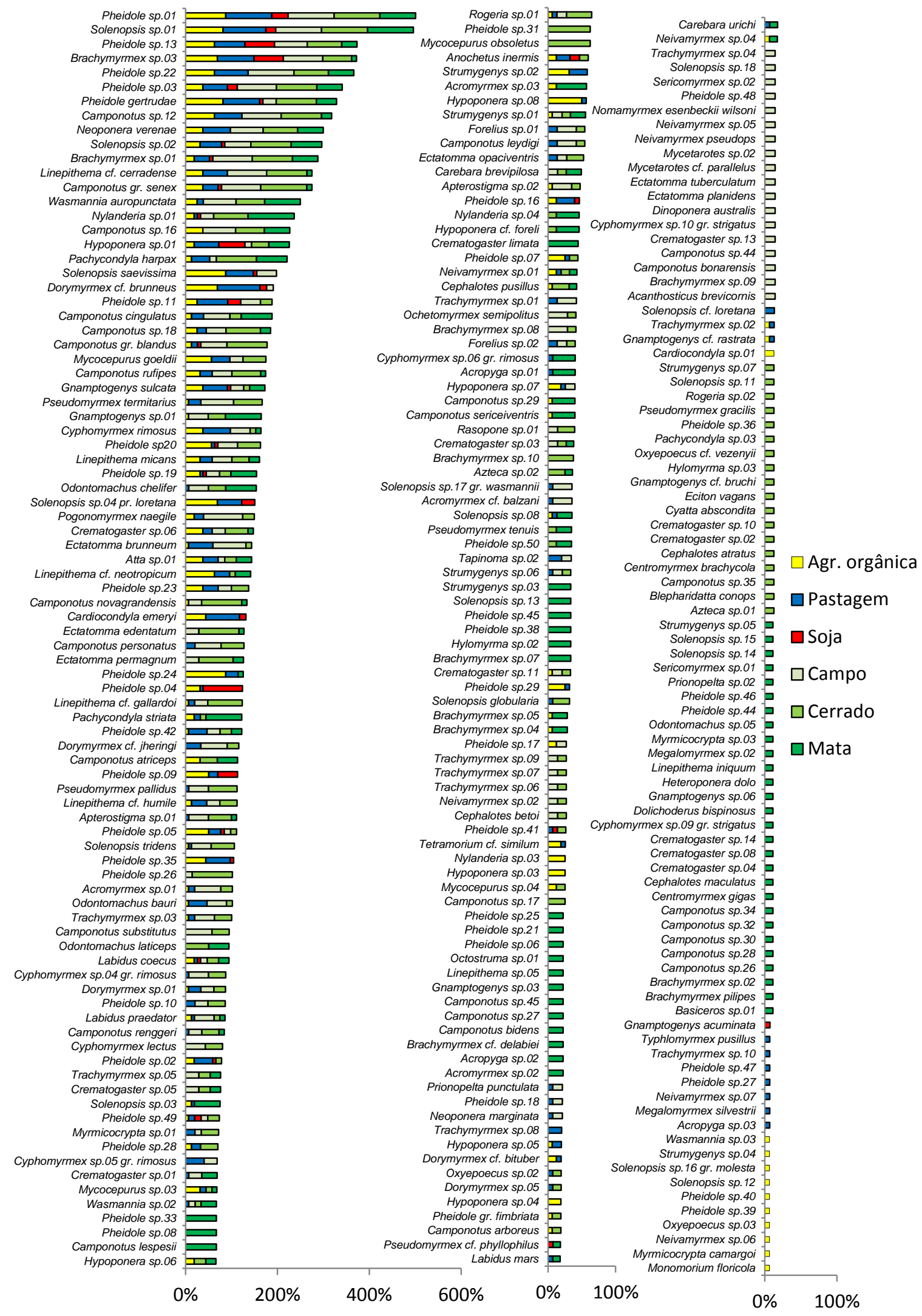

Figura 1.9. Ocorrência das espécies em cada um dos sistemas amostrados com armadilha de queda no solo (pitfall) no ano de 2013 e 2014 no Distrito Federal. Para a comparação entre sistemas, foi realizada uma correção, transformando o número de ocorrência em porcentagem. A ocorrência em cada sistema corresponde a $100 \%$, a soma dos seis sistemas corresponde a $600 \%$. 


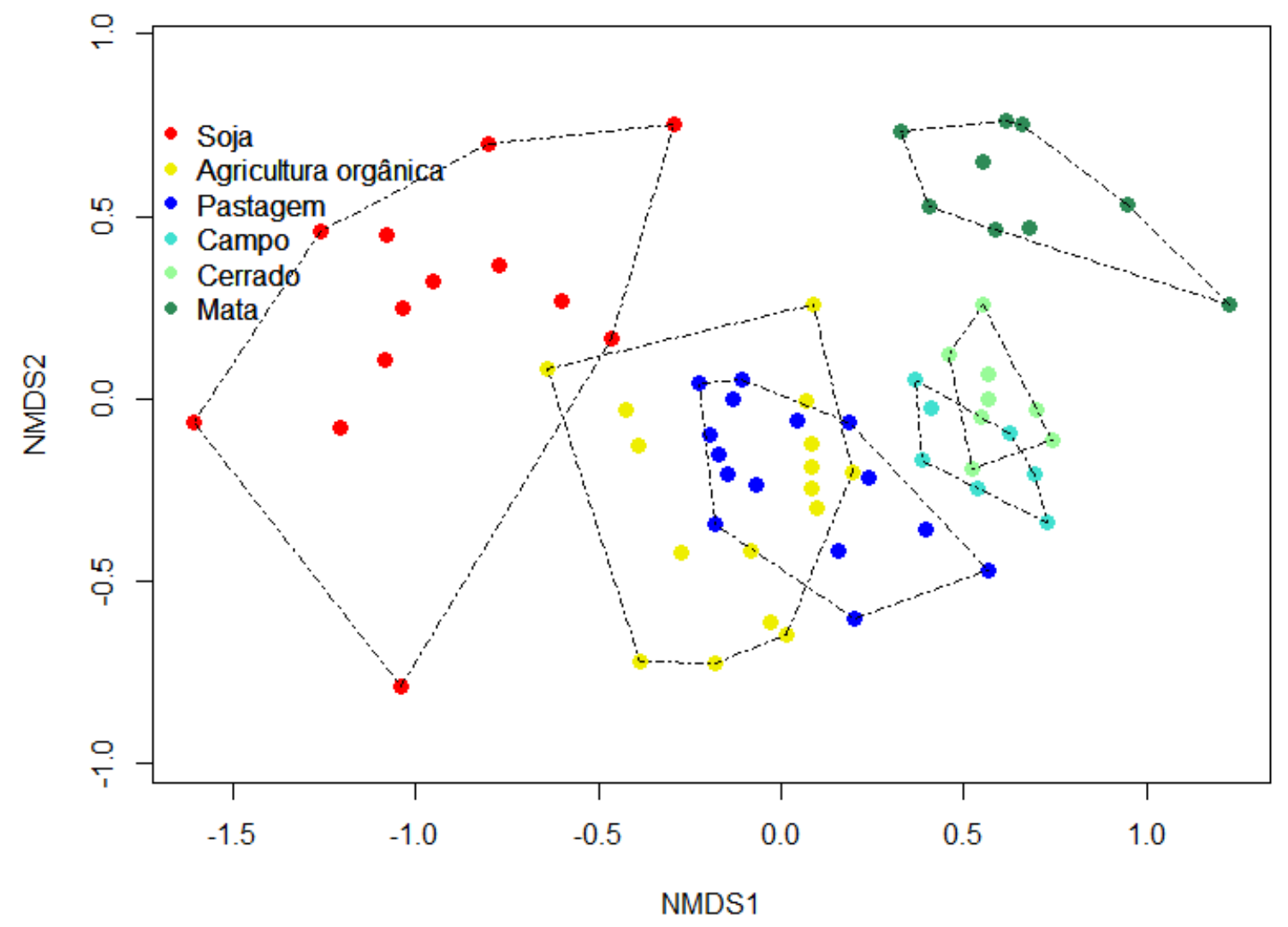

Figura 1.10. Escalonamento multidimensional não métrico (NMDS) baseado na matriz de presença e ausência que aproxima as localidades com a composição de formigas mais similares entre si. Baseado em coletas realizadas em 2013 e 2014 no Distrito Federal com armadilhas de queda (pitfall). 


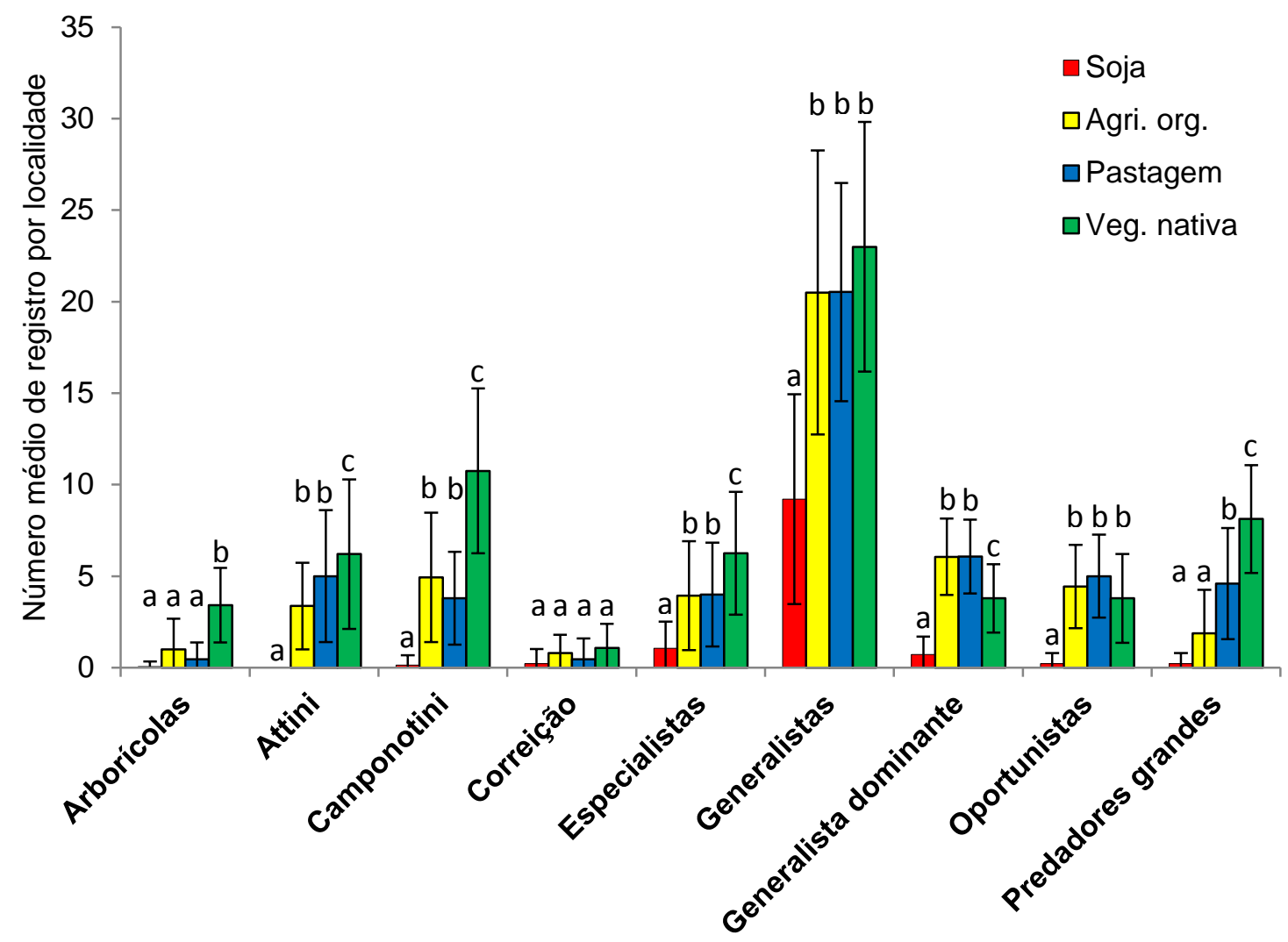

Figura 1.11. Número médio de registro por localidade de formigas pertencentes a diferentes grupos funcionais, coletadas em 2013 e 2014 no Distrito Federal com armadilhas de queda (pitfall). Para mais informação sobre as espécies e características dos grupos funcionais veja o Anexo I. Letras diferentes indicam diferenças significativas entre os habitats e barras o desvio padrão. 


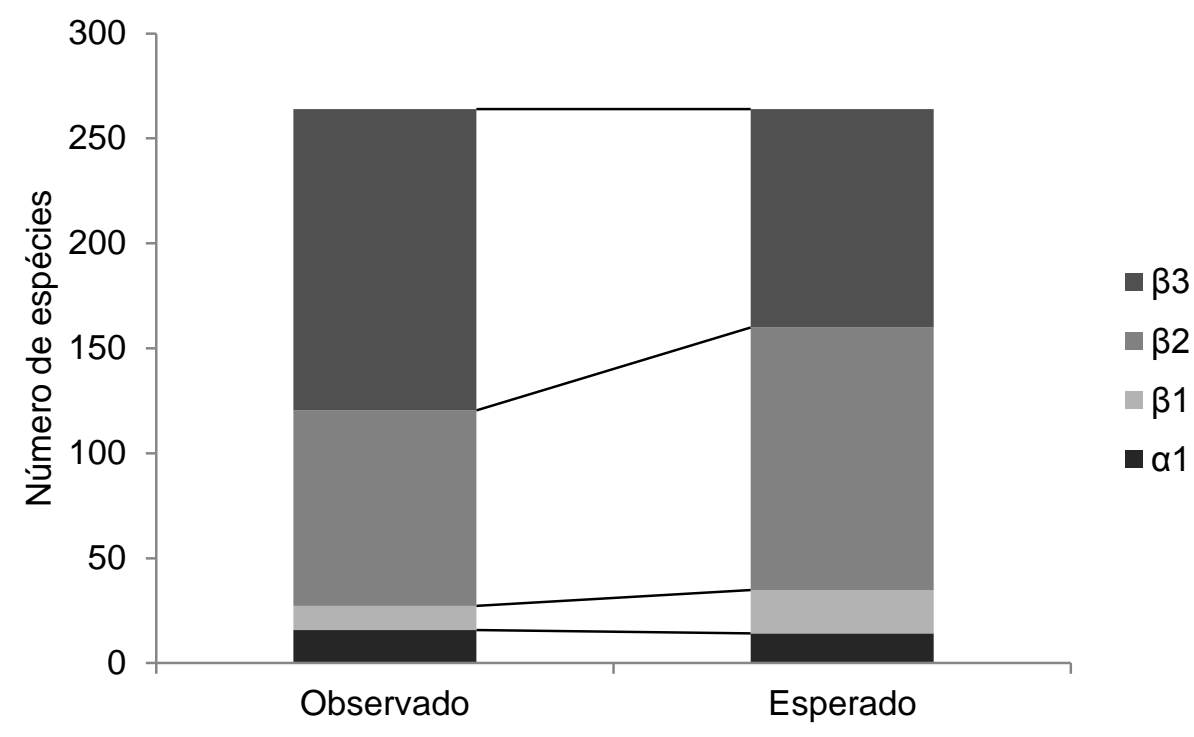

Figura 1.12. Análise de partição aditiva de diversidade de formigas no Distrito Federal. $\alpha 1$ é o número médio de espécies nas parcelas. $\beta 1$ é a troca de espécies entre parcelas dentro da mesma localidade. $\beta 2$ é a troca de espécies entre localidades pertencentes ao mesmo tipo de agrossistema ou fitofisionomia. $\beta 3$ é a troca de espécies entre os diferentes tipos de agrossistemas e fitofisionomias. Para todos os valores observados a diferença foi significativa $(\mathrm{p}<0,001)$ em comparação ao modelo esperado. 

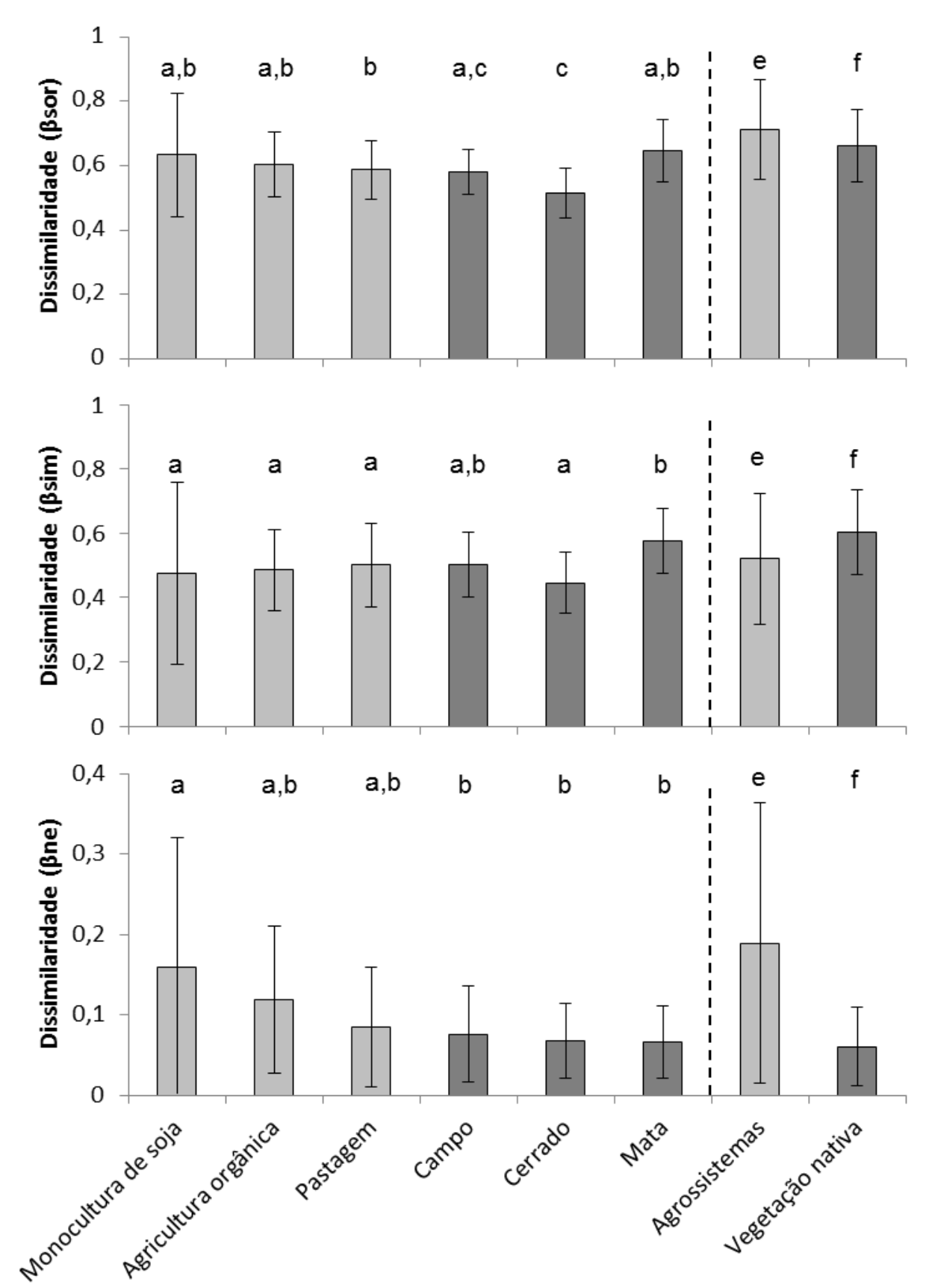

Figura 1.13. Valores da diversidade $\beta$ baseados em dados de presença e ausência de espécies de formigas coletadas por armadilha de queda (pitfall) em 2013 e 2014 no Distrito Federal. ßsor representa a soma de $\beta$ sim (troca de espécies, ou seja, turnover) e $\beta$ nes (aninhamento). Letras representam diferenças significativas. Para as categorias Agrossistemas e Vegetação nativa foi feito um teste $t$ com os valores das comparações par a par obtida nas diferentes matrizes. Para as demais categorias foi realizado o teste não paramétrico de Kruskal-Wallis. 

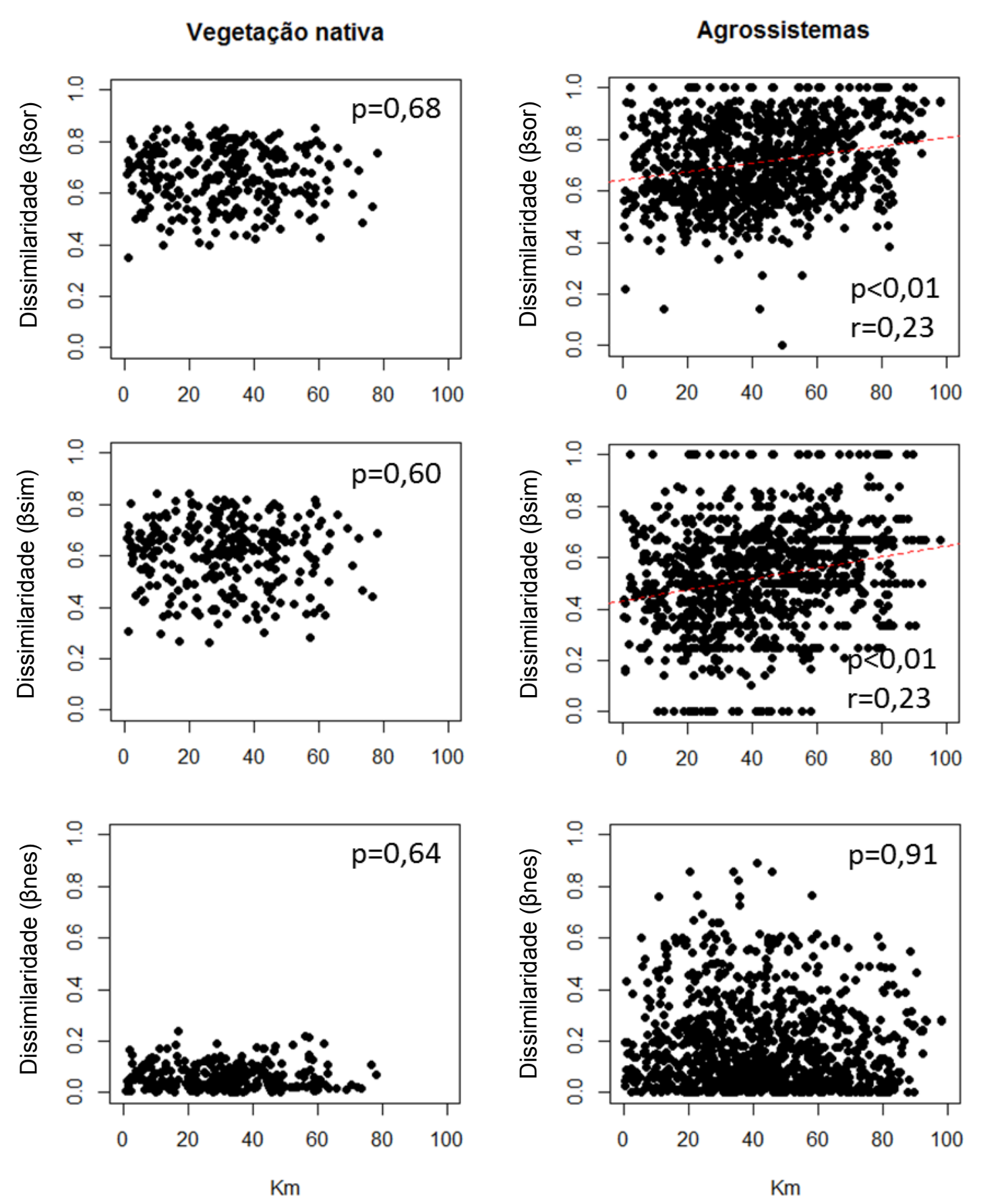

Figura 1.14. Relação entre a dissimilaridade da fauna de formiga ( $\beta$ sor, $\beta$ sim e $\beta$ nes) e a relação com a distância entre as localidades da Vegetação nativa e dos Agrossistemas. A Correlação de Pearson (r) e a significância computada usando análise de Mantel estão dispostas dentro dos gráficos. Os pontos correspondem aos valores de comparação par a par entre as localidades amostradas em 2013 e 2014 com armadilhas de queda (pitfall) no Distrito Federal. 
Tabela 1.2. Espécies de formigas e seus respectivos valores de indicação para diferentes tipos de habitats. Os dados foram obtidos a partir de armadilhas de queda (pitfall) nos anos de 2013 e 2014 no Distrito Federal. Todas as espécies e índices abaixo foram obtidos de resultados significativos. Habitats: AO = agricultura orgânica e Past= pastagem. Cores brancas, amarelas e verdes indicam um gradiente de baixo a alto valor de indicação.

\begin{tabular}{|c|c|c|c|c|c|c|c|}
\hline Espécie & Soja & $\mathrm{AO}$ & Past & Campo & Cerrado & Mata & Valor $p$ \\
\hline Pheidole sp.04 & 0,59 & 0,08 & 0,00 & 0,00 & 0,00 & 0,00 & 0,00 \\
\hline Pheidole sp.09 & 0,16 & 0,22 & 0,04 & 0,00 & 0,00 & 0,00 & 0,03 \\
\hline Pheidole sp.35 & 0,00 & 0,61 & 0,06 & 0,00 & 0,00 & 0,01 & 0,01 \\
\hline Camponotus gr. blandus & 0,00 & 0,44 & 0,01 & 0,00 & 0,00 & 0,00 & 0,00 \\
\hline Solenopsis saevissima & 0,00 & 0,39 & 0,18 & 0,09 & 0,00 & 0,00 & 0,00 \\
\hline Solenopsis sp.04 pr. Ioretana & 0,05 & 0,31 & 0,19 & 0,00 & 0,00 & 0,00 & 0,00 \\
\hline Nylanderia sp.01 & 0,00 & 0,28 & 0,08 & 0,00 & 0,01 & 0,08 & 0,00 \\
\hline Camponotus gr. senex & 0,00 & 0,25 & 0,00 & 0,00 & 0,00 & 0,00 & 0,00 \\
\hline Brachymyrmex sp.01 & 0,00 & 0,25 & 0,00 & 0,00 & 0,00 & 0,00 & 0,02 \\
\hline Dorymyrmex cf. brunneus & 0,01 & 0,25 & 0,46 & 0,01 & 0,00 & 0,00 & 0,00 \\
\hline Solenopsis sp.02 & 0,00 & 0,20 & 0,19 & 0,02 & 0,23 & 0,06 & 0,04 \\
\hline Pheidole gertrudae & 0,00 & 0,20 & 0,01 & 0,00 & 0,00 & 0,00 & 0,04 \\
\hline Pheidole sp.24 & 0,00 & 0,18 & 0,27 & 0,00 & 0,00 & 0,00 & 0,00 \\
\hline Hypoponera sp.08 & 0,00 & 0,11 & 0,15 & 0,27 & 0,15 & 0,08 & 0,00 \\
\hline Cardiocondyla emeryi & 0,02 & 0,15 & 0,41 & 0,00 & 0,00 & 0,00 & 0,00 \\
\hline Pheidole sp.11 & 0,04 & 0,03 & 0,24 & 0,10 & 0,03 & 0,00 & 0,04 \\
\hline Pheidole sp.02 & 0,01 & 0,04 & 0,20 & 0,00 & 0,02 & 0,00 & 0,04 \\
\hline Acromyrmex sp.01 & 0,00 & 0,00 & 0,23 & 0,12 & 0,00 & 0,00 & 0,01 \\
\hline Solenopsis tridens & 0,00 & 0,00 & 0,20 & 0,00 & 0,00 & 0,00 & 0,01 \\
\hline Linepithema cf. gallardoi & 0,00 & 0,00 & 0,20 & 0,36 & 0,01 & 0,00 & 0,00 \\
\hline Camponotus novagrandensis & 0,00 & 0,00 & 0,10 & 0,28 & 0,05 & 0,00 & 0,00 \\
\hline Pachycondyla striata & 0,00 & 0,02 & 0,03 & 0,49 & 0,04 & 0,00 & 0,00 \\
\hline Linepithema cf. neotropicum & 0,00 & 0,06 & 0,04 & 0,11 & 0,22 & 0,01 & 0,02 \\
\hline Nylanderia sp.03 & 0,00 & 0,05 & 0,10 & 0,27 & 0,28 & 0,00 & 0,02 \\
\hline Hypoponera sp.03 & 0,00 & 0,05 & 0,04 & 0,27 & 0,36 & 0,00 & 0,02 \\
\hline Pheidole sp.29 & 0,00 & 0,03 & 0,07 & 0,11 & 0,26 & 0,15 & 0,03 \\
\hline Pheidole sp.22 & 0,00 & 0,03 & 0,02 & 0,10 & 0,30 & 0,03 & 0,03 \\
\hline Cyphomyrmex sp06 gr. rimosus & 0,00 & 0,00 & 0,00 & 0,35 & 0,15 & 0,00 & 0,01 \\
\hline Trachymyrmex sp.08 & 0,00 & 0,00 & 0,02 & 0,32 & 0,06 & 0,00 & 0,05 \\
\hline Pseudomyrmex termitarius & 0,00 & 0,00 & 0,04 & 0,31 & 0,23 & 0,00 & 0,01 \\
\hline Solenopsis sp.03 & 0,00 & 0,01 & 0,04 & 0,26 & 0,27 & 0,11 & 0,00 \\
\hline Cyphomyrmex sp05 gr. rimosus & 0,00 & 0,00 & 0,03 & 0,26 & 0,20 & 0,00 & 0,02 \\
\hline Dorymyrmex cf. jheringi & 0,00 & 0,00 & 0,01 & 0,23 & 0,00 & 0,00 & 0,01 \\
\hline Myrmicocrypta sp.01 & 0,00 & 0,00 & 0,01 & 0,23 & 0,00 & 0,00 & 0,05 \\
\hline Acropyga sp.01 & 0,00 & 0,00 & 0,00 & 0,23 & 0,18 & 0,00 & 0,01 \\
\hline Acromyrmex sp.03 & 0,00 & 0,02 & 0,01 & 0,21 & 0,02 & 0,01 & 0,00 \\
\hline Trachymyrmex sp.01 & 0,00 & 0,00 & 0,01 & 0,21 & 0,16 & 0,00 & 0,03 \\
\hline Wasmannia auropunctata & 0,00 & 0,02 & 0,01 & 0,20 & 0,16 & 0,24 & 0,04 \\
\hline Gnamptogenys sp.01 & 0,00 & 0,00 & 0,04 & 0,19 & 0,00 & 0,00 & 0,00 \\
\hline Camponotus sericeiventris & 0,00 & 0,01 & 0,01 & 0,18 & 0,43 & 0,00 & 0,01 \\
\hline
\end{tabular}

Continua... 


\begin{tabular}{|c|c|c|c|c|c|c|c|}
\hline Espécie & Soja & $\mathrm{AO}$ & Past & Campo & Cerrado & Mata & $p$ value \\
\hline Labidus praedator & 0,00 & 0,01 & 0,04 & 0,17 & 0,03 & 0,24 & 0,03 \\
\hline Cyphomyrmex sp04 gr. rimosus & 0,00 & 0,00 & 0,00 & 0,17 & 0,24 & 0,00 & 0,04 \\
\hline Brachymyrmex sp.10 & 0,00 & 0,00 & 0,00 & 0,17 & 0,23 & 0,01 & 0,00 \\
\hline Pseudomyrmex pallidus & 0,00 & 0,00 & 0,00 & 0,16 & 0,35 & 0,00 & 0,00 \\
\hline Camponotus personatus & 0,00 & 0,00 & 0,01 & 0,07 & 0,46 & 0,00 & 0,03 \\
\hline Camponotus sp.17 & 0,00 & 0,00 & 0,00 & 0,02 & 0,75 & 0,00 & 0,02 \\
\hline Camponotus substitutus & 0,00 & 0,00 & 0,00 & 0,00 & 0,63 & 0,00 & 0,00 \\
\hline Cyphomyrmex lectus & 0,00 & 0,00 & 0,00 & 0,00 & 0,63 & 0,00 & 0,03 \\
\hline Pheidole sp.31 & 0,00 & 0,00 & 0,00 & 0,06 & 0,60 & 0,01 & 0,00 \\
\hline Mycocepurus obsoletus & 0,00 & 0,00 & 0,00 & 0,06 & 0,57 & 0,01 & 0,00 \\
\hline Pheidole sp.26 & 0,00 & 0,00 & 0,00 & 0,06 & 0,45 & 0,04 & 0,00 \\
\hline Odontomachus chelifer & 0,00 & 0,00 & 0,00 & 0,00 & 0,38 & 0,00 & 0,01 \\
\hline Pheidole sp.28 & 0,00 & 0,01 & 0,07 & 0,01 & 0,35 & 0,20 & 0,05 \\
\hline Ectatomma edentatum & 0,00 & 0,00 & 0,00 & 0,00 & 0,26 & 0,21 & 0,00 \\
\hline Apterostigma sp.01 & 0,00 & 0,00 & 0,00 & 0,00 & 0,25 & 0,00 & 0,03 \\
\hline Rogeria sp.01 & 0,00 & 0,01 & 0,00 & 0,03 & 0,24 & 0,42 & 0,03 \\
\hline Camponotus sp.29 & 0,00 & 0,01 & 0,01 & 0,03 & 0,22 & 0,00 & 0,01 \\
\hline Ectatomma brunneum & 0,00 & 0,00 & 0,06 & 0,03 & 0,20 & 0,00 & 0,00 \\
\hline Camponotus sp.18 & 0,00 & 0,02 & 0,06 & 0,00 & 0,20 & 0,00 & 0,01 \\
\hline Camponotus rufipes & 0,00 & 0,03 & 0,01 & 0,00 & 0,01 & 0,49 & 0,04 \\
\hline Linepithema cf. cerradense & 0,00 & 0,03 & 0,00 & 0,00 & 0,00 & 0,35 & 0,02 \\
\hline Pogonomyrmex naegile & 0,00 & 0,02 & 0,01 & 0,00 & 0,00 & 0,41 & 0,00 \\
\hline Camponotus cingulatus & 0,00 & 0,01 & 0,00 & 0,00 & 0,00 & 0,28 & 0,04 \\
\hline Pachycondyla harpax & 0,00 & 0,01 & 0,00 & 0,00 & 0,00 & 0,28 & 0,00 \\
\hline Acromyrmex cf. balzani & 0,00 & 0,00 & 0,01 & 0,00 & 0,00 & 0,28 & 0,02 \\
\hline Solenopsis sp17 gr. wasmannii & 0,00 & 0,00 & 0,01 & 0,00 & 0,00 & 0,28 & 0,02 \\
\hline Ectatomma permagnum & 0,00 & 0,00 & 0,00 & 0,00 & 0,00 & 0,22 & 0,00 \\
\hline Odontomachus laticeps & 0,00 & 0,00 & 0,00 & 0,00 & 0,00 & 0,22 & 0,02 \\
\hline Camponotus sp.45 & 0,00 & 0,00 & 0,00 & 0,00 & 0,00 & 0,22 & 0,03 \\
\hline Pheidole sp.25 & 0,00 & 0,00 & 0,00 & 0,00 & 0,00 & 0,22 & 0,03 \\
\hline Camponotus bidens & 0,00 & 0,00 & 0,00 & 0,00 & 0,00 & 0,22 & 0,03 \\
\hline Linepithema sp.05 & 0,00 & 0,00 & 0,00 & 0,00 & 0,00 & 0,22 & 0,04 \\
\hline Acropyga sp.02 & 0,00 & 0,00 & 0,00 & 0,00 & 0,00 & 0,22 & 0,04 \\
\hline Gnamptogenys sp.03 & 0,00 & 0,00 & 0,00 & 0,00 & 0,00 & 0,22 & 0,04 \\
\hline Pheidole sp.21 & 0,00 & 0,00 & 0,00 & 0,00 & 0,00 & 0,22 & 0,04 \\
\hline Brachymyrmex cf. delabiei & 0,00 & 0,00 & 0,00 & 0,00 & 0,00 & 0,22 & 0,04 \\
\hline Pheidole sp.06 & 0,00 & 0,00 & 0,00 & 0,00 & 0,00 & 0,22 & 0,04 \\
\hline Camponotus sp.27 & 0,00 & 0,00 & 0,00 & 0,00 & 0,03 & 0,24 & 0,04 \\
\hline Octostruma sp.01 & 0,00 & 0,00 & 0,00 & 0,00 & 0,03 & 0,24 & 0,05 \\
\hline Hypoponera cf. foreli & 0,00 & 0,00 & 0,00 & 0,12 & 0,09 & 0,29 & 0,02 \\
\hline Nylanderia sp.04 & 0,00 & 0,00 & 0,00 & 0,00 & 0,00 & 0,33 & 0,02 \\
\hline Brachymyrmex sp.07 & 0,00 & 0,00 & 0,00 & 0,00 & 0,00 & 0,33 & 0,00 \\
\hline Hylomyrma sp.02 & 0,00 & 0,00 & 0,00 & 0,00 & 0,00 & 0,33 & 0,00 \\
\hline Solenopsis sp.13 & 0,00 & 0,00 & 0,00 & 0,00 & 0,00 & 0,33 & 0,00 \\
\hline
\end{tabular}




\begin{tabular}{lccccccc}
\hline Espécie & Soja & AO & Past & Campo & Cerrado & Mata & p value \\
\hline Pheidole sp.38 & 0,00 & 0,00 & 0,00 & 0,00 & 0,00 & 0,33 & $\mathbf{0 , 0 1}$ \\
Pheidole sp.45 & 0,00 & 0,00 & 0,00 & 0,00 & 0,00 & 0,33 & $\mathbf{0 , 0 1}$ \\
Strumygenys sp.03 & 0,00 & 0,00 & 0,00 & 0,11 & 0,09 & 0,37 & $\mathbf{0 , 0 1}$ \\
Crematogaster limata & 0,00 & 0,00 & 0,00 & 0,00 & 0,00 & 0,44 & $\mathbf{0 , 0 0}$ \\
Camponotus lespesii & 0,00 & 0,00 & 0,00 & 0,00 & 0,00 & 0,67 & $\mathbf{0 , 0 0}$ \\
Pheidole sp.08 & 0,00 & 0,00 & 0,00 & 0,00 & 0,00 & 0,67 & $\mathbf{0 , 0 0}$ \\
Pheidole sp.33 & 0,00 & 0,00 & 0,00 & 0,00 & 0,00 & 0,67 & $\mathbf{0 , 0 0}$ \\
\hline
\end{tabular}




\section{Discussão}

\section{Efeitos sobre a riqueza}

Os resultados mostram que as conversões de áreas nativas do Cerrado em agrossistemas causam a perda da diversidade local. Porém, a magnitude desta perda está condicionada ao tipo de agrossistema implantado, pois monoculturas de soja causam maior queda na diversidade do que pastagens ou agricultura orgânica. Kessler et al. (2009) utiliza o termo "divergência das condições ecológicas" para explicar porque alguns tipos de uso da terra têm maior impacto sobre a biodiversidade. Basicamente esse termo tenta retratar que quanto mais diferente é a condição pós-conversão em relação à vegetação original, geralmente simplificando ou aumentando a intensidade do manejo do sistema, menor é a diversidade esperada. Estes são resultados semelhantes aos encontrados na literatura científica, que apresenta diversos estudos, com diferentes táxons, mostrando que a conversão de habitats naturais e intensificação dos agrossistemas acarretam em redução e mudanças na composição das espécies, além de mudanças na estrutura do funcionamento do ecossistema (e.g. Jones et al. 2003; Hole et al. 2005; Tylianakis et al. 2005; Flynn et al. 2009; Marichal 2014; Uchida \& Ushimaru 2014; Van Meerbeek et al. 2014; Hausberger \& Korb 2016; Lu et al. 2016; Ribeiro-Neto et al. 2016).

Dos diversos exemplos na literatura de como a conversão de áreas nativas para a produção de alimentos impactaram a fauna local, talvez o mais bem estudado seja a produção de café na América Latina, segundo o qual em uma revisão feita por Philpott et al. (2008) foi notada uma redução na diversidade de formigas. Porém, a magnitude dessa redução depende do tipo de manejo da terra (monocultivo de café ou café à sombra de árvores nativas), além de refletir nos serviços ecológicos (Perfecto \& Vandermeer 2001; Armbrecht \& Perfecto 2003; Philpott \& Armbrecht 2006; Armbrecht \& Gallego 2007). Padrões similares de redução na 
diversidade ou riqueza de formigas em sistemas de plantio são encontrados também na Amazônia (Solaris et al. 2015), Argentina (Bestelmeyer \& Wiens 1996), Austrália (Hoffmann \& Andersen 2003), África (Lemessa et al. 2015), China (Lu et al. 2016) e México (Cuatle et al. 2016).

Então, apesar da perda de espécies devido à conversão da vegetação nativa em agrossistemas ser um padrão global bem conhecido, a magnitude desse efeito e sua interação com os diversos tipos de agrossistemas ainda são, em sua maioria, desconhecidos. A redução na diversidade, encontrada ao longo do presente trabalho, é maior que a descrita por Pacheco et al. (2013) e Frizzo \& Vasconcelos (2013).

De certo modo, este trabalho retrata como monoculturas de soja com aplicação de agrotóxicos, aração e gradagem do solo, períodos de entresafra sem cobertura viva do solo e a dessecação pré-plantio são formas de manejo que tornam esses campos um ambiente de difícil sobrevivência, tanto para insetos praga (sendo sua existência a principal causa para realização de parte destes manejos, como aplicação de agrotóxico e dessecação pré-plantio) como para todos os outros seres vivos. Para esse processo muitos autores tem utilizado a expressão intensificação do uso da terra, uma forma de, independentemente do tipo de cultura plantada, caracterizar o manejo destas áreas como causa para as diferentes riquezas encontradas nestes ambientes (Tscharntke et al. 2005).

Em contrapartida, as pastagens praticamente não são manejadas, possuindo uma riqueza de espécies de formigas maior que as de áreas de soja (como já descrito por Frizzo e Vasconcelos 2013), já que aparentemente o pastejo em si pouco afeta a diversidade de formigas (Bestelmeyer \& Wiens 2001). Nessas áreas, o efeito mais importante é o efeito indireto da ocupação de espécies exóticas de gramíneas (Barton et al. 2016), que são competitivamente superiores às gramíneas nativas e reduzem a diversidade da flora e fauna (Pivello et al. 1999; Almeida et al. 2011). A expansão das gramíneas exóticas de origem 
africana é considerada uma das grandes ameaças ao Cerrado (Hoffmann et al. 2004; Klink \& Machado 2005).

Já as áreas de agricultura orgânica surpreendentemente são tão diversas como as de pastagem, sugerindo que os agrotóxicos, assim como as técnicas de manejo, são os grandes responsáveis pela redução da diversidade em áreas de agricultura convencional (Hole et al. 2005; Winqvist et al. 2011). Além da restrição no uso de agrotóxicos em geral, as áreas de orgânicos possuem uma grande heterogeneidade local, o plantio de flores para fornecer recurso alternativo para os predadores e irrigação constante ao longo do ano, de modo que sempre há matéria verde e, consequentemente, herbívoros e outros organismos que podem servir de fonte de alimentação para as formigas (Frizzo, observação pessoal). Além disso, diferente do que encontrado na soja, as áreas de agricultura orgânica possuem faixas de terra com plantas perenes e árvores, onde o solo não é revolvido nessa região, potencialmente agindo como refúgio para formigas que nidificam no solo ou nas próprias árvores (Frizzo \& Vasconcelos 2013).

\section{Efeito sobre a composição}

Quanto à composição, as espécies que conseguem persistir nos sistemas agrícolas geralmente são caracterizadas por serem de hábito generalista, recrutarem para monopolizar os recursos disponíveis em campo e/ou apresentarem comportamento dominante, como os gêneros Pheidole e Solenopsis (Pacheco et al. 2013). Outro exemplo de espécies comuns nos agrossistemas analisados são as formigas oportunistas com tolerância a temperaturas altas, como as do gênero Dorymyrmex e Linepithema (Cuezzo 2011; Farji-Brener et al. 2002). Além destas há as formigas generalistas de tamanho muito reduzido ( 1,5 mm), como Brachymyrmex e as chamadas "thief ants", também do gênero Solenopsis, que ocorrem tanto em ambientes naturais como em perturbados, incluindo residências em áreas urbanas. 
Já as formigas arborícolas, os predadores grandes, as especialistas e as tribos Attini e Camponotini, com a conversão de áreas nativas em sistemas agrícolas, sofrem uma redução na sua ocorrência (Figura 1.11). Isso ocorre tanto devido as mudanças ambientais, como ao combate direto (manejo para reduzir a população), no caso das formigas pertencentes a tribo Attini. É evidente também que o tipo de uso da terra afeta a ocorrência de determinados grupos funcionais de formigas em diferentes graus de magnitude. Em geral, o plantio de soja é o tipo de uso da terra que tem mais efeitos negativos para quase todos os grupos funcionais, enquanto agricultura orgânica e pastagem apresentam valores intermediários entre soja e vegetação nativa.

Mas a grande diferença na composição das formigas que ocorre entre os agrossistemas e a vegetação nativa está associada às espécies raras ou às que ocorreram apenas uma vez. Como pode se observar na figura 1.7 , as áreas de vegetação nativa têm 3,5 vezes mais espécies únicas (amostradas uma única vez) do que os agrossistemas, apesar do esforço amostral nestas áreas ser quase a metade do ocorrido nos agrossistemas. Estas espécies raras geralmente apresentam algum aspecto da morfologia, ecologia ou comportamento especializado (Didham et al. 1996; Gibb et al. 2015). Campos et al. (2011) demonstraram que a fauna de formigas do Cerrado é caracterizada por uma grande proporção de formigas raras (45\% das espécies ocorrem em menos do que 5\% das amostras), comparativamente à savana Australiana (onde $27 \%$ das espécies são raras). Resultados semelhantes também foram encontrados para Lepidópteros (Price et al. 1995). Esse fato torna ainda mais preocupante o avanço dos agrossistemas sobre as áreas nativas, visto que as espécies raras são as mais suscetíveis à extinção devido a baixa densidade e pouca flexibilidade que possuem para persistir em ambientes perturbados (Didham et al. 1996).

Muitos trabalhos discutem quais são os fatores que podem ser limitantes para a colonização de uma área agrícola, e a maioria parece supor o local para nidificação como 
fator limitante, que pode ser, além do solo, serapilheira, galhos caídos sobre o solo e o estrato arbóreo arbustivo (Philpott \& Foster 2005; Armbrecht et al. 2006). Porém, Frizzo et al. (2011) relataram que a passagem do fogo no cerrado stricto sensu, não altera a comunidade de formigas no solo, mesmo esse consumindo toda a serapilheira, galhos caídos e o estrato arbustivo, o que indica que para o Cerrado, talvez esse não seja o efeito primordial. Tem-se também, como outro provável fator limitante, o favorecimento das espécies generalistas e dominantes que podem ter um efeito supressivo no estabelecimento e ação de diversas espécies, gerando exclusão competitiva devido às interações interespecíficas (Pacheco et al. 2013). Também foi encontrado na literatura que, arar o solo pode reduzir em até cinco vezes a ocorrência de formigas na folhagem de culturas (Pereira et al. 2010). No entanto, com exceção do último, estudos que isolem cada um destes possíveis fatores que afetam as formigas nos sistemas agrícolas são inexistentes ou não foram encontrados.

Do ponto de vista conservacionista, também é importante ressaltar a mudança na composição em função da fitofisionomia nativa coletada (Pacheco \& Vasconcelos 2012), o que aumenta ainda mais a importância de conservação de múltiplas áreas nativas. De certo modo, com exceção das espécies invasoras, em tese, todas as espécies encontradas nos sistemas agrícolas são capazes de sobreviver nos sistemas nativos, no entanto, o inverso não é verdadeiro. Visto que ambientes convertidos em sistemas agrícolas não contêm espécies, que são relativamente comuns em ambientes naturais. Isso fica claro quando analisamos a composição de espécies da formação florestal, a qual apresenta o maior número de espécies indicadoras singulares (dados do IndVal, Tabela 1.2). Isso significa que nas áreas de mata existem muitas espécies únicas que não são capazes de persistir em sistemas agrícolas ou nas áreas de vegetação nativas mais abertas. Resultados semelhantes no Cerrado também foram encontrados para Drosophilideos, no qual Mata \& Tidon (2013) discutem que, apesar das matas de galeria ocuparem menos de $10 \%$ do Cerrado, uma grande parte da diversidade 
demonstra uma preferência ou associação a esse ambiente. Isso também foi observado para outros táxons, incluindo árvores (Hoffman et al. 2003), mamíferos (Redford \& Fonseca, 1986), formigas (Pacheco \& Vasconcelos 2012) besouros (Durães et al. 2005), algumas famílias de lepidópteros (Brown \& Gifford 2002), entre outros.

Áreas de vegetação nativa de cerrado e campo também apresentam algumas espécies únicas, que provavelmente seriam extintas localmente se houvesse a conversão destas em sistemas agrícolas. Mesmo pastagem e agricultura orgânica sendo sistemas menos impactantes sobre a biodiversidade de formigas, estas apresentam uma composição distinta em relação às áreas nativas, as quais contêm um número maior de espécies arborícolas, crípticas, predadores especialistas e espécies de tamanho relativo, pequeno e grande. Essas mudanças no número de espécies com diferentes tamanhos, também é relatado por Senior $e t$ al. (2013) para aves, besouros e formigas.

\section{Partição aditiva e multiplicativa da diversidade}

A comunidade de formigas do Cerrado é caracterizada pela maior presença de espécies raras (Campos et al. 2011), o que influencia o não aninhamento da comunidade como um todo (Almeida-Neto et al. 2008). De certo modo, as espécies mais abundantes persistem na maioria dos habitats e, à medida que se tornam raras, elas demostram um padrão de preferência de habitat (Figura 1.13). O que a análise de partição aditiva de diversidade revela é que o fator mais importante para a diversidade de formigas no Distrito Federal é a existência de uma maior diversidade de habitats (sensu Pacheco e Vasconcelos 2012).

Separando a diversidade $\beta$ em dois fatores, que afetam a troca de espécies entre as diferentes localidades, verificou-se que a magnitude da diferença de $\beta$ sor entre sistemas agrícolas e as fitofisionomias nativas é pequena, apesar de significativa (figura 1.13). Pode-se notar que há uma troca maior de espécies (dissimilaridade $\beta$ sor) nos sistemas agrícolas em 
comparação às fitofisionomias nativas, e que essa dissimilaridade é mais em função do aninhamento $(\beta$ nes) do que da troca de espécies propriamente dita $(\beta \operatorname{sim})$. Resultados semelhantes foram encontrados por Solar et al. (2015) na Amazônia, porém com o dobro dos valores de aninhamento encontrados no Cerrado. Isso demonstra que no Cerrado as áreas de produção agrícola, com o aumento da intensificação do uso da terra, têm causado a homogeneização biótica (McKinney \& Lockwood, 1999), porém não tão drástica como as encontradas na Amazônia.

Além disso, um segundo padrão na diversidade $\beta$ sor foi encontrado, mas este associado apenas à troca de espécies ( $\beta$ sim) e aos agrossistemas. Na figura 1.14, observou-se que a dissimilaridade entre as localidades agrícolas aumenta à medida que estas localidades ficam mais distantes entre si. Isso significa que a composição de espécies nos agrossistemas é influenciada em função do local em que se encontra. A mudança da composição em função da posição geográfica é um fato esperado, porém não a distâncias tão pequenas quanto $100 \mathrm{~km}$. Baselga (2010) também encontrou influência da distância sobre as variáveis de dissimilaridade ( $\beta$ sor, $\beta$ sim e $\beta$ nes), mas em um gradiente com quase $3.000 \mathrm{~km}$ de distância. 


\section{Conclusão}

A conversão da vegetação nativa do Cerrado em sistemas de produção agricola causa uma perda local na diversidade e mudança na composição da mirmecofauna. Esta perda está associada ao tipo de sistema agrícola, sendo a monocultura de soja, em comparação a áreas de agricultura orgânica e pastagens, o que causa maior decréscimo na riqueza local.

De modo geral, os grupos de formigas que apresentam maior especificidade, como nidificar em árvores ou ter uma especialização alimentar, são os que têm a maior redução em relação a sua frequência de ocorrência. Estes grupos que apresentam especializações, na maioria dos casos já são espécies naturalmente raras (de baixa frequência), sendo estes os principais promotores de biodiversidade e, potencialmente, as espécies mais ameaçadas de extinção local no Cerrado.

Outro fator importante em termos de conservação é que diferentes fitofisionomias nativas do Cerrado possuem uma composição de espécies distintas. As áres de formação florestal apresentam a fauna mais exclusiva, com muitas espécies únicas que não ocorrem nas áreas nativas de cerrado stricto sensu, campo e principalmente nos agrossistemas. Já as formações savanicas (cerrado stricto sensu e campo) apesar de também apresentam espécies exclusivas, possuem um subconjunto de espécies que são capazes de persistir ou colonizar os sistemas agrícolas.

Duas implicações práticas deste trabalho são: (1) reavaliar como está sendo realizado o manejo das áreas agrícolas, principalmente monocultura de soja, para, assim, diminuir seu impacto; (2) considerar que, em futuras ações conservacionistas, áreas de pastagem e agricultura orgânica possam ser sistemas de produção preferenciais ou incentivados no entorno de áreas de conservação ou nas de relevante biodiversidade, como zonas de 
amortização de impacto ou até mesmo corredores entre fragmentos de cerrado stricto sensu e campo. 


\section{Capítulo II - Variação nas taxas de remoção de biomassa pela mirmecofauna de solo sobre diferentes tipos de uso da terra}

\section{Resumo}

Um dos principais efeitos da redução na biodiversidade sugerido pelos pesquisadores tem sido a redução ou perda de funções do ecossistema, mas esse não é um efeito universal. No Cerrado, já observamos que sistemas agrícolas causam uma redução na biodiversidade de formigas, mas não se sabe como as funções do ecossistema desempenhadas por estas são afetadas. O principal objetivo deste estudo foi avaliar se a conversão de áreas nativas em sistemas agrícolas, afeta a remoção de biomassa realizada por formigas, uma importante função do ecossistema ligada à decomposição e predação. Para isso, foram utilizadas iscas de sardinha (simulando organismos animais), banana (simulando recurso atrativo vegetal) e sementes de gramíneas, em áreas nativas (campo, cerrado stricto sensu e mata) e áreas agrícolas (plantio de soja, pastagens e agricultura orgânica). Exceto para soja, os dados mostram que formigas removem mais sardinha, do que banana, e removem muito pouca semente. Porém, existe um efeito relacionado ao tipo de uso da terra, já que apenas as áreas de soja tiveram níveis significativamente baixos de remoção de sardinha. Para a isca de sementes não foi detectado nenhum efeito porque pouca biomassa é removida, tanto nas áreas nativas como nos sistemas agrícolas. Já para a isca de banana, os dados sugerem existir um efeito de redundância com outro grupo da macrofauna. No entanto, a biomassa da macrofauna (excluindo-se formigas) não explica essa remoção de biomassa. Também não foi detectado efeito da composição de espécies de formigas sobre as biomassas removidas. A remoção de biomassa de sardinha e banana está correlacionada à riqueza de formigas, indicando que os efeitos sobre a função do ecossistema dependem das particularidades de cada função avaliada (como tipo de recurso), do tipo de uso da terra e da riqueza de formigas no local. 


\section{Introdução}

A expansão dos sistemas agrícolas tem efeitos sobre a biodiversidade local (Pacheco et al. 2013) e global (Newbold et al. 2015), sendo a magnitude destes efeitos dependente das características locais, táxon e tipo de sistema agrícola implantado (Flynn et al. 2009; Kessler et al. 2009; Bommarco et al. 2014). Porém, tão ou mais importante quanto o efeito sobre a biodiversidade é responder qual é o efeito da expansão dos sistemas agrícolas sobre o funcionamento do ecossistema.

A hipótese da biodiversidade-função do ecossistema, uma teoria que começou a ser amplamente debatida no começo da década de 1990, prediz que uma redução na biodiversidade (número de espécies, variabilidade genética e etc...) causa decréscimo nos processos do ecossistema (Srivastava \& Vellend 2005). Porém, este não é um efeito universal (e.g. Birkhofen et al. 2015), revisões e metanálises a respeito deste assunto têm chegado a uma mesma conclusão: a redução da biodiversidade, reduz a funcionalidade do ecossistema dependendo das características locais, da função do ecossistema analisada e do tipo de perturbação (Hopper et al. 2005; Cardinale et al. 2006; Allan et al. 2013).

Essa grande quantidade de resultados divergentes, encontrados nos estudos sobre serviços do ecossistema devido aos efeitos da antropização, torna a previsibilidade destes impactos complexas e dependentes de estudos que foquem em diferentes ambientes, processos e tipos de perturbação. No entanto, além de existirem relativamente poucos estudos, boa parte destes tem analisado comunidades de plantas ou comunidades aquáticas em experimentos manipulativos (Srivastava \& Vellend 2005; Allan et al. 2013; Cardinale et al. 2006), dando pouca importância aos processos ecológicos que dependem da fauna terrestre.

Dentre esses processos ecológicos, pode-se citar a predação e a decomposição, exercidos pela fauna terrestre, de fundamental importância para o funcionamento e regulação 
do ecossistema (De Groot et al. 2002). Isso porque a predação possibilita o controle das diversas populações, incluindo consumidores e plantas. Já a fauna detritívora, atua no processo de decomposição e ciclagem da matéria orgânica contribuindo para a fertilidade do solo e nutrição das plantas.

Existem poucos estudos que avaliam como a expansão da agricultura afeta a biodiversidade e como isso reflete nos processos ecológicos do Cerrado, cujo alto grau de endemismo e de degradação é um dos maiores no mundo (Myers et al. 2000). A expansão da fronteira agrícola no Cerrado é uma realidade, com áreas densamente ocupadas, principalmente ao sul deste bioma (Sano et al. 2010). Os impactos desta ocupação têm sido avaliados utilizando diversos táxons, sendo as formigas um dos principais objetos de estudo (revisado por Folgarait 1998; Ribas et al. 2012), isso porque é um dos táxons mais abundantes e de maior biomassa em ambientes tropicais (Fittkau \& Klinge 1973). Só no Cerrado, estima-se que elas consomem de 13 a $17 \%$ da biomassa foliar de plantas lenhosas por ano (Costa et al. 2008). As formigas também podem atuar como predadores, podendo controlar a população de pragas agrícolas (Risch \& Carroll 1982; López \& Potter 2000; Philpott \& Armbrecht 2006; Armbrecht \& Gallego 2007; Howe et al. 2009; Styrsky \& Eubanks 2010; Gonthier et al. 2013; Offenberg 2015) ou como predadores e/ou dispersores de sementes (Wall et al. 2005), principalmente das que contenham elaiosoma (um apêndice atrativo da semente) (Ferreira et al. 2011). Outro importante serviço ecológico é a remoção de biomassa orgânica da superfície para o subsolo, melhorando as qualidades nutricionais do solo (Folgarait 1998).

As formigas possuem diferentes hábitos alimentares, sendo que a maioria das espécies é onívora, existindo algumas poucas espécies estritamente predadoras, granívoras ou que atuam como herbívoros (Fernández 2003). Além disso, de toda a gama de recursos utilizados pelas formigas, sempre há algum elemento nutricional limitante para seu desenvolvimento e o 
da colônia e, por isso, estudos apontam que as formigas têm demonstrado preferência alimentar justamente por aqueles recursos que contenham uma proporção maior desses elementos limitantes (Kaspariz \& Yanovlak 2001; Bihn et al. 2008; Kaspari et al. 2008; Vieira \& Vasconcelos 2014).

Em vista disso, este estudo tem o objetivo de avaliar as taxas de remoção de biomassa por formigas de diferentes tipos de recursos (sensu Vieira \& Vasconelos 2014) entre ecossistemas nativos e agrícolas. Para tanto, foram selecionadas áreas de agricultura orgânica, plantações de soja, pastagens, além de áreas nativas de campo, cerrado stricto sensu e formações florestais. Especificamente procuramos responder às seguintes perguntas: (1) existe diferença na biomassa removida entre recursos que simulam organismos animais, apêndices atrativos de sementes e sementes de gramíneas? (2) Mudanças no uso da terra afetam as taxas de remoção de biomassa? (3) Quais variáveis locais explicam melhor a quantidade de biomassa removida, riqueza de formigas, composição da assembleia de formigas ou biomassa do restante da macrofauna? 


\section{Metodologia}

\section{Área de estudo}

O estudo foi realizado no Distrito Federal que abrange uma área de mais de 5.800 $\mathrm{Km}^{2}$, localizado centralmente a $15^{\circ} 47^{\prime} \mathrm{S}$ e $47^{\circ} 55^{\prime} \mathrm{O}$. As localidades amostradas foram as mesmas descritas no Capítulo I (Tabela 1.1 e Figura 1.1). O experimento foi instalado em 69 localidades, porém o ponto P-03 foi pisoteado por gado e os pontos VN-18 e VN-21 foram atacados de forma massiva por formigas de correição, por isso estes foram excluídos das análises estatísticas. Assim, ao todo, foram analisados: 14 plantios de soja convencional, 14 pastagens, 16 áreas de agricultura orgânica (sendo duas destas, AO-15 e AO-16, plantio de soja orgânica) e 22 áreas de vegetação nativa. A escolha dos sistemas agrícolas, pastagem e plantio de soja, se devem a esses serem os tipos de uso da terra mais comuns no Cerrado, representando $27,6 \%$ e $11,7 \%$ da área do bioma respectivamente (Sano et al. 2010). Já as áreas de agricultura orgânica representam uma forma alternativa de produção de alimento vegetal sem o uso de agrotóxicos e cujo mercado esta em rápida expansão (Rigby \& Cáceres 2001; Blanc 2009; ABRASCO 2015). Das 22 áreas de vegetação nativa, optou-se por coletar nas três fitofisionomias também mais comuns da região, as quais são: cinco localidades de formações campestres, oito de cerrado stricto sensu e nove de formações florestais (Figuras 1.1 e 1.2$)$

Segundo a classificação de Köppen (1948), o clima nessa região é do tipo Aw, apresentando forte sazonalidade, com um verão chuvoso e o inverno seco. As temperaturas médias mensais podem variar de 22 a $27^{\circ} \mathrm{C}$ e a precipitação anual média é de $1.500 \mathrm{~mm}$ (Klink \& Machado 2005). Todas as localidades estão situadas dentro do bioma Cerrado (para mais informações sobre a vegetação nativa veja Oliveira-Filho \& Ratter 2002). 


\section{Protocolo amostral}

Nesse experimento, foram desenvolvidas "estações de remoção de biomassa" para medir as taxas de remoção de recurso por formigas de forma concomitante com a amostragem da fauna descrita no Capítulo I (Figura 2.1). Essas estações consistiam em potes plásticos de um litro de volume, com tampa e com vários furos laterais, em forma de semicírculo com 1 $\mathrm{cm}$ de altura e $2 \mathrm{~cm}$ de largura, para a macrofauna ter acesso ao interior do pote (Figura 2.2 A). Dentro de cada estação foi disponibilizada uma quantidade de recurso (também denominado de isca) de massa conhecida e, após 24 horas, essas estações foram recolhidas e a biomassa do recurso foi novamente mensurada, a fim de se determinar a quantidade de biomassa removida pela macrofauna. Apenas para o tratamento contendo semente estas foram secas em estufa a $50 \mathrm{C}^{\circ}$, por 24 horas, antes e depois do experimento em campo, devido à grande absorção de água pelas sementes no campo. Para as iscas de sardinha e banana, estas eram preparadas em laboratório, individualizadas e congeladas, em porções de massa variando entre 20 a 30 gramas por estação de remoção de biomassa, até serem utilizadas no experimento. As sementes de gramíneas também foram individualizadas em porções de 15 gramas por estação de remoção de biomassa.

Em campo, este experimento foi montado ao mesmo tempo, que a instalação das armadilhas de queda do Capítulo I. Para cada parcela amostral citadas no Capítulo I, também foram instaladas 12 estações de remoção de biomassa que ficara em campo por 24 horas (Figura 2.2 - B). Para cada localidade as parcelas amostrais foram istaladas no mesmo momento, sendo a escolha do tipo de isca em cada parcela escolhida de forma aleatória. Ao final do experimento, as estações foram removidas e as formigas presentes dentro das estações de remoção de biomassa foram coletadas e identificadas em laboratório.

Nos extremos da parcela foram colocadas duas estações de remoção de biomassa, denominadas "controle". Isso porque os recursos poderiam perder massa por dessecação, 
então foi criado um controle para abater estes valores dos tratamentos. Essas estações controle possuiam o mesmo número e tamanho de abertura que as demais, porém estas eram posicionadas na lateral próximas à tampa do pote (parte superior). Isto foi feito para diminuir o acesso da fauna em geral ao recurso. Além disso, foi instalada uma tira com três centímetros de altura de armadilha adesiva amarela no lado interno do pote, esta circundava o pote impedindo o acesso de animais à isca (Figura 2.2 - C). Então a massa perdida após 24 horas foi considerada uma perda de umidade do recurso para o ambiente e, por isso, foi proporcionalmente descontada da massa inicial das outras estações de remoção de biomassa. Adicionalmente, as tampas de todas as estações de remoção de biomassa e controle foram cobertas por uma camada de aproximadamente $3 \mathrm{~mm}$ de impermeabilizante emborrachado branco, a fim de diminuir o aumento interno de temperatura.

Dentro de cada localidade, as três parcelas amostrais foram diferenciadas pelo tipo de recurso contido nas estações de remoção de biomassa. Foram utilizados três tipos de recurso que simulam os alimentos mais comuns disponíveis para as formigas e que poderiam ser comprados em grande quantidade e baixo custo. Esses recursos são sardinha enlatada (simulando organismos animais), banana da variedade prata (simulando alimentos como o arilo de sementes ou frutos) e um composto de sementes não beneficiadas, em proporção de massa iguais, de arroz, alpiste e painço (simulando sementes de gramíneas nativas do cerrado). Em termos nutricionais, sardinha é muito rica em sódio, proteína e gorduras totais, banana é rica em açúcar e as sementes em carboidratos (USDA 2016). Para a preparação da sardinha, o óleo foi drenado e depois foi esmagada com um garfo, já a banana foi descascada e esmagada.

Considerou-se que a utilização de iscas exógenas ao ambiente não inviabilizaria os resultados porque todas as localidades são réplicas idênticas umas das outras. Portanto, comparação entre localidades diferentes refletem diferenças reais. Além disso, 
independentemente da diferença de intensidade do odor entre os tipos de isca, observações de campo indicam que todas as iscas são rapidamente encontradas e monopolizadas, apenas para sementes, não foi observado monopolização (ou defesa do recurso). Outros estudos similares usaram atrativos exógenos para formigas, como: atum e biscoito (Fayle et al. 2011) e isca para pesca feitas de pelotas de minhoca (Gray et al. 2015).

Junto com o experimento também foram instalados, nas parcelas, um sistema de choque elétrico para evitar o acesso de animais (vertebrados) atraídos pelas iscas. Esse sistema foi montado a partir de pedaços de tela de galinheiro presos à parte superior das estações de remoção de biomassa (Figura 2.2 - D) e ligados, por fios elétricos encapados, a um aparelho de cerca elétrica para gado. Este aparelho era alimentado por uma bateria de 12 volts e estava conectado por meio de fios a todas as estações de remoção de biomassa. Após a instalação desse sistema, nenhuma estação de controle ou de tratamento foi destruída, ao contrário de como ocorreu no experimento piloto.

\section{Cálculo da biomassa}

As taxas de remoção de biomassa por estação foram calculadas, descartando a massa dos potes, de acordo com a função:

$$
\mathrm{Br}=(\mathrm{PI} \times \mathrm{Fc})-(\mathrm{PF})
$$

Onde:

Br é biomassa removida;

PI é a massa inicial de alimento posto dentro da estação;

Fc é o fator de correção de biomassa perdida por dessecação (fórmula do cálculo abaixo);

PF é a massa do conteúdo restante do alimento após 24 horas; 
Para corrigir a massa de alimento perdida devido à dessecação nas estações de remoção de biomassa foi calculado um fator de correção $(\mathrm{Fc})$, com as estações de biomassa controle, a partir da seguinte fórmula:

$$
\mathrm{Fc}=\mathrm{PFc} / \mathrm{PI}
$$

Onde:

Fc é o fator de correção de biomassa perdida por dessecação;

PFc é a massa do conteúdo restante do alimento após 24 horas;

PI é a massa inicial de alimento posto dentro da estação controle.

Ainda após esses cálculos foi realizada a soma dos valores de alimento removidos por parcela amostral. Como algumas poucas estações de remoção de biomassa foram acidentalmente perdidas (Tabela 2.1), foi realizada uma estimativa do valor total de biomassa removida por parcela amostral. Esse valor foi obtido através da fórmula:

$\mathrm{Br}_{\text {estimada }}=(\Sigma \mathrm{Br}$ por ponto amostral $/ \mathrm{Nt}) \times 12$

Onde:

$\Sigma \mathrm{Br}$ por ponto amostral é o somatório de toda biomassa removida em uma parcela amostral;

Nt é o número de estações de remoção de biomassa resgatado por parcela amostral e;

12 seria o número de estações que deveria existir em cada parcela amostral.

Além dos dados de riqueza já obtidos no capítulo I, para essas mesmas áreas também foram utilizados dados de biomassa das formigas amostradas nos pitfalls e do restante da macrofauna amostrada. Para isso, todos os invertebrados capturados nos pitfalls, por parcela amostral, foram separados entre formigas e outros invertebrados. Logo após isso, as amostras foram secas a $60 \mathrm{C}^{\circ}$ por 48 horas e depois pesadas em uma balança analítica com precisão de $0,001 \mathrm{~g}$. 


\section{Análise dos dados}

Os dados foram separados em quatro categorias de habitats: plantio de soja, agricultura orgânica, pastagem e vegetação nativa. Para a vegetação nativa foi realizado o agrupamento dos pontos que contemplam diferentes fitofisionomias por que: (1) entre eles não há diferenças significavas nos padrões de remoção de biomassa e; (2) a separação por fitofisionomia formar grupos com número de amostras muito pequenos para a realização das análises estatísticas subsequentes.

Todas as análises foram realizadas utilizando o programa R ( $\mathrm{R}$ Development Core Team 2008). A primeira análise visou verificar se o número de estações de remoção de biomassa com formigas, ao final das 24 horas em campo, diferiria entre os distintos habitats. Para esta análise, o número de estações de remoção de biomassa com formigas, em cada parcela amostral foi contabilizado. Em seguida foi realizada uma análise de modelos lineares generalizados, utilizando a função glm do R.

Para determinar qual é o tipo de isca (banana, sardinha ou semente) mais removido no sistema, foi realizado o teste não paramétrico de Friedman em blocos (devido à heterogeneidade de variâncias), com um teste a posteriori (Hollander \& Wolfe 1973) utilizando a função posthoc.friedman.nemenyi.test do pacote PMCMR (Pohlert 2016). Devido às áreas de soja apresentarem um padrão visualmente diferente dos demais, quanto à preferência por recurso (Figura 2.4), para estas foi realizada a mesma análise em separado. Em seguida, para determinar se a biomassa removida de cada tipo de isca, também varia em função dos diferentes tipos de habitats avaliados foi realizada uma análise de modelos lineares generalizados, utilizando a função glm do R.

Foi realizada também uma correlação Pearson entre a riqueza e massa de formigas amostradas por localidade. Devido à não normalidade de parte dos dados e problemas de heterocedasticidade e presença constante de pontos tendenciando os resíduos, não foi possível 
realizar nenhuma análise englobando múltiplos fatores e suas interações para explicar quais as variáveis influenciam a remoção de biomassa de sardinha, banana e semente. Por isso, foram feitas análises de correlação de Pearson entre as variáveis: riqueza de formigas, biomassa da macrofauna, biomassa removida de sardinha, biomassa removida de banana e biomassa removida de semente. Novamente, como as áreas de soja apresentam padrões diferentes na avaliação visual dos gráficos, outra matriz de correlação de Pearson foi construída sem a presença das áreas de soja.

Para determinar se a composição de espécies de formigas influencia nas taxas de remoção de biomassa, foi realizada uma análise de correspondência canônica (CCA), utilizando a função cca do pacote vegan (Oksanen et al. 2016). Essa análise foi feita baseada em uma matriz de espécies por locais, sendo contabilizada a frequência de ocorrência por parcela (com três parcelas por localidade). As variáveis avaliadas na CCA foram: tipo de habitat, número de espécies de formigas por localidade, biomassa da macrofauna e biomassa removida de sardinha, banana e semente.

Para validar a CCA foi realizado um teste para detectar multicolinearidade entre as variáveis analisadas usando a função vif.cca, do pacote vegan (Oksanen et al. 2016) - neste teste, se os valores de VIF (fator de inflação da variância) forem maiores que 10 indicam multicolinearidade entre duas variáveis (Belsley et al. 1980). Em seguida, foi utilizada a função anova.cca (pacote vegan), com 999 permutações, para determinar se o modelo, as variáveis e os eixos de explicação são significativos. Estas análises (CCA) foram repetidas mais uma vez, com uma matriz utilizando apenas as espécies consideradas abundantes (que ocorreram mais de 30 vezes). 


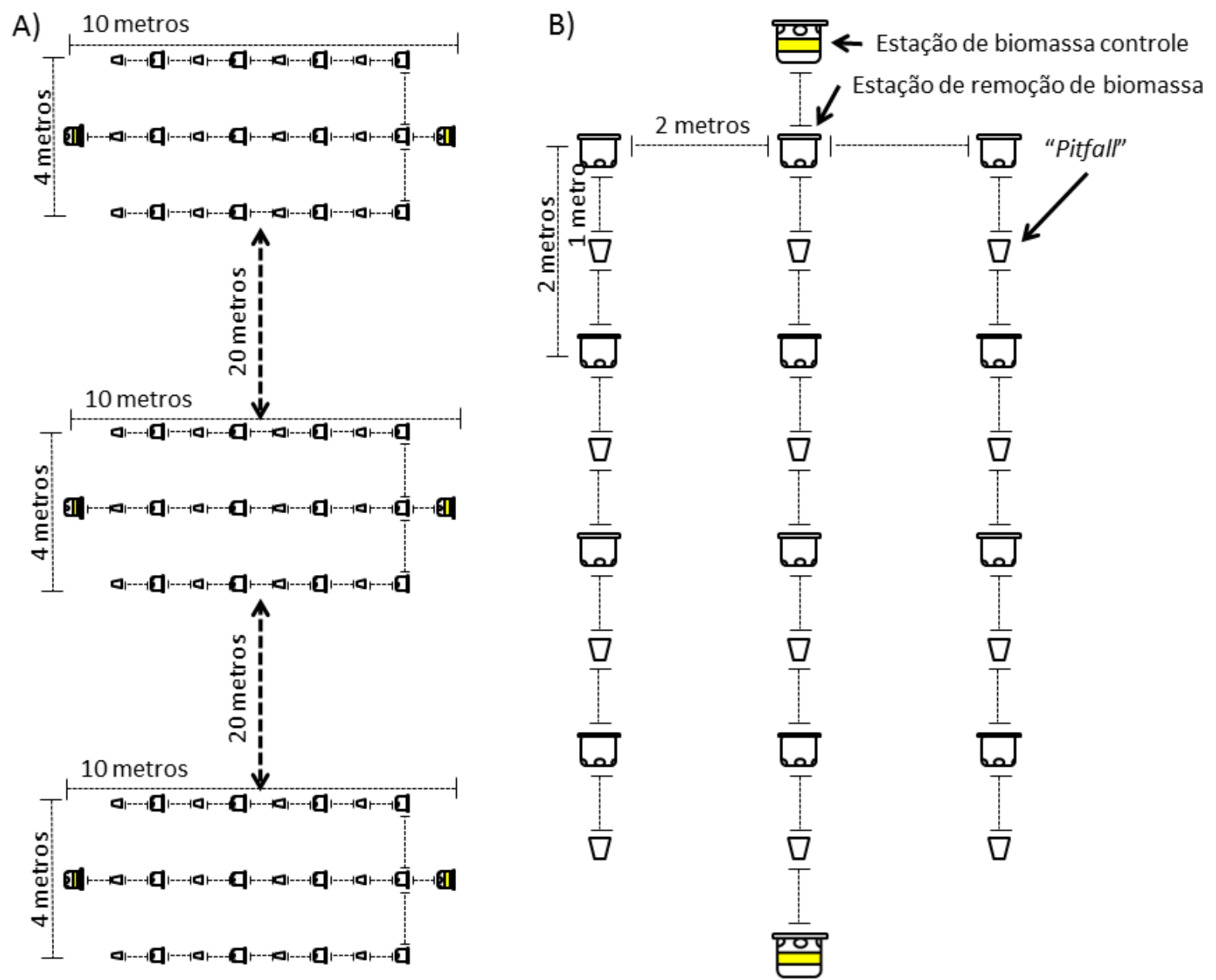

Figura 2.1. Esquema da metodologia de amostragem realizada em 2013 e 2014 no Distrito Federal. A) Como as três parcelas amostrais estavam distribuídas ao longo de cada localidade, sendo que em cada uma das parcelas foi utilizado um tipo de isca escolhido de forma aleatória (sardinha, banana e semente). B) Esquema da parcela amostral, tendo 12 estações de remoção de biomassa, 12 pitfalls e duas estações de biomassa controle nas extremidades. 

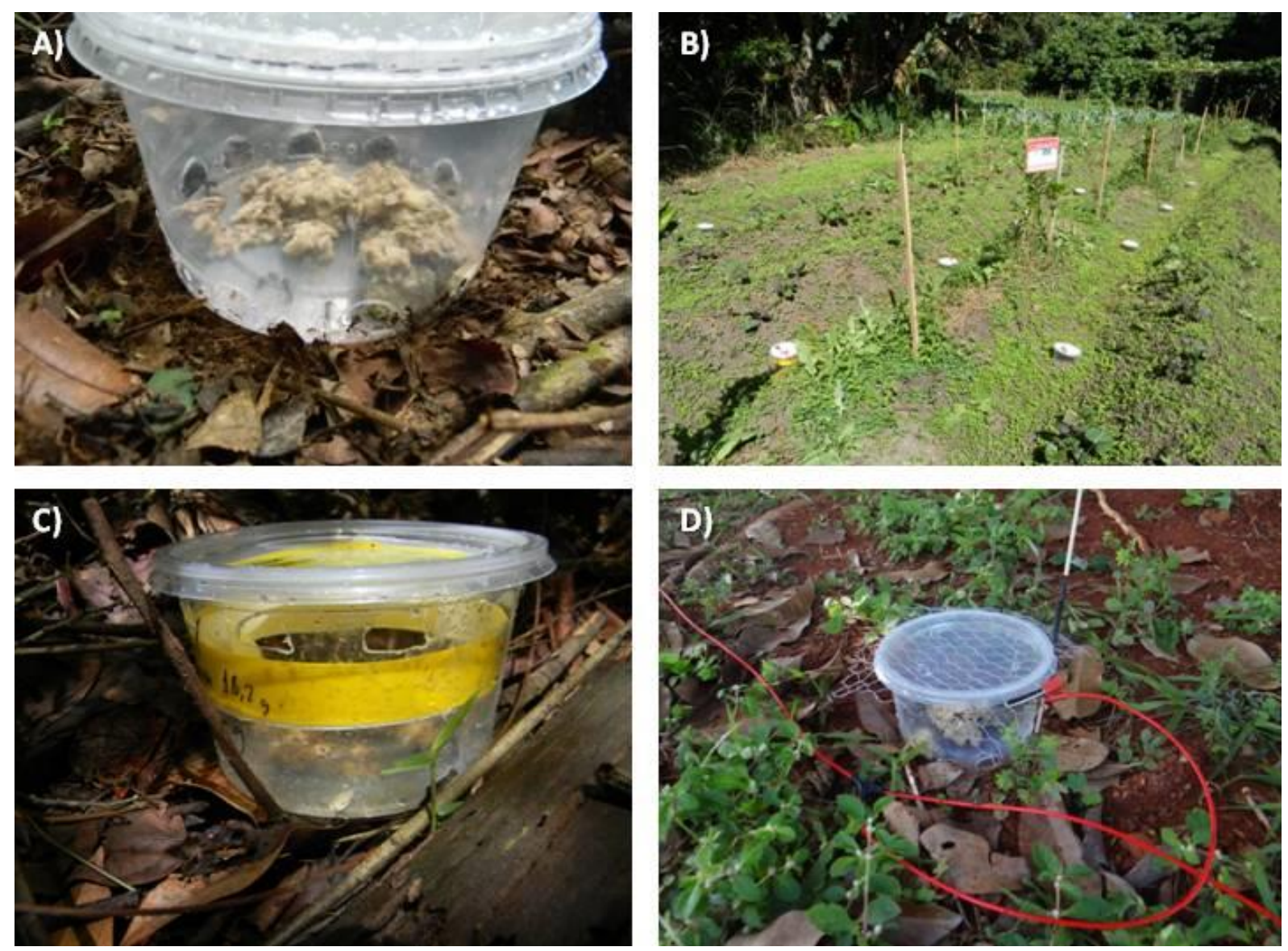

Figura 2.2. Fotografias da metodologia de estudo realizada em 2013 e 2014 no Distrito Federal. A) Estação de remoção de biomassa com isca de sardinha. B) Fotografia da parcela amostral em uma área de agricultura orgânica. C) Estação de biomassa controle. D) Estação de remoção de biomassa com uma tela de arame ligada a um aparelho de choque elétrico. 
Tabela 2.1. Número de estações de remoção de biomassa e estações controle recuperadas e perdidas em campo, no ano de 2013 e 2014 no Distrito Federal. Os sistemas estudados foram áreas de agricultura orgânica (Agri org), pastagem, plantações de soja (Soja) e áreas de vegetação nativa (Veg nat). Obs.: O alto número de estações perdidas com o tipo de isca semente se deve ao fato de que, acidentalmente, durante o trabalho de campo algumas armadilhas viravam e as sementes caiam para fora da estação, sendo estas eliminadas das análises.

\begin{tabular}{|c|c|c|c|c|c|}
\hline Alimento & Sistema & $\begin{array}{l}\text { № de estações de } \\
\text { remoção de biomassa }\end{array}$ & Perdidos & $\begin{array}{l}\text { № de estações de } \\
\text { biomassa controle }\end{array}$ & Perdidos \\
\hline \multirow[t]{5}{*}{ Banana } & Agri org & 192 & 0 & 32 & 0 \\
\hline & Pastagem & 166 & 2 & 28 & 0 \\
\hline & Soja & 168 & 0 & 28 & 0 \\
\hline & Veg nat & 264 & 0 & 44 & 0 \\
\hline & Total & 790 & 2 & 132 & 0 \\
\hline \multirow[t]{5}{*}{ Sardinha } & Agri org & 190 & 2 & 32 & 0 \\
\hline & Pastagem & 168 & 0 & 28 & 0 \\
\hline & Soja & 166 & 2 & 28 & 0 \\
\hline & Veg nat & 261 & 3 & 43 & 1 \\
\hline & Total & 785 & 7 & 131 & 1 \\
\hline \multirow[t]{5}{*}{ Semente } & Agri org & 183 & 9 & 29 & 3 \\
\hline & Pastagem & 149 & 19 & 26 & 2 \\
\hline & Soja & 167 & 1 & 25 & 3 \\
\hline & Veg nat & 255 & 9 & 41 & 3 \\
\hline & Total & 754 & 38 & 121 & 11 \\
\hline Total Ger & & 2.329 & 47 & 384 & 12 \\
\hline
\end{tabular}




\section{Resultados}

Ocorrência de formigas nas estações de remoção de biomassa

As formigas foram o principal grupo de insetos observado dentro das estações de remoção de biomassa após 24 horas de coleta (Anexo IV). Apenas em 55 estações de remoção de biomassa, das mais de 2.300 em campo, haviam outros insetos, como moscas, mariposas e gafanhotos. Isso indica que a maior parte da biomassa removida é devido à ação das formigas, principalmente porque em observações de campo anteriores notou-se que formigas monopolizam iscas atrativas atacando qualquer outro organismo que se aproxime. Porém, é importante destacar que, no término do experimento, a porcentagem de estações de remoção de biomassa ocupadas por formigas variaram significativamente entre os habitats, sendo menores nas áreas de monocultura de soja (variação na ocupação de 0 a 57\%, com média de $13 \%$, Figura 2.3).

\section{Taxas de remoção de biomassa entre os tipos de recursos}

As formigas foram capazes de remover relativamente grandes quantidades de biomassa por parcela (máximo removido de 237g, toda sardinha disponível na localidade VN18), mas isso depende do tipo de alimento (de acordo com o teste em blocos de Fridman, $\mathrm{X}^{2}=85,534, \mathrm{df}=2, \mathrm{p}<0,001$ ) (Figura 2.4-A). Assim, detectou-se que sardinha foi o recurso mais removido, com uma média de 87,2g ( $\sigma \pm 22,8)$, seguido de banana (média de 70,1g, $\sigma$ \$30,5) e, por último, de semente (média de 7,6g, $\sigma \pm 7,1$ ) (maior $\mathrm{p}=0,017$ ).

Porém apenas para soja o padrão é diferente dos demais (Figura 2.4-B), pois há uma diferença estatística entre a biomassa removida para os diferentes tipos de recurso (teste em blocos de Fridman, $\mathrm{X}^{2}=26,143, \mathrm{df}=2, \mathrm{p}<0,001$ ), sendo a banana o mais removido (média de 74,8g, $\sigma \pm 13,6$ ). Já a diferença entre a biomassa removida de banana e sardinha é 
marginalmente significativa $(\mathrm{p}=0,06)$, pois em média foi removido 44,5g $(\sigma \pm 12)$ de sardinha. Enquanto que, para semente, continuou havendo uma remoção significativamente $(p<0,01)$ inferior aos demais tipos de recursos (média de 5,3, $\sigma \pm 7,1$ ).

\section{Taxas de remoção de biomassa entre os habitats}

Em relação à biomassa removida por tipo de habitat (soja, pastagem, agricultura orgânica ou vegetação nativa) não foram encontradas diferenças significativas para banana (GLM, $\left.\mathrm{F}_{3,62}=0,4565, \mathrm{p}=0,7136\right)$ e para semente ( $\mathrm{GLM}, \mathrm{F}_{3,62}=1,2561, \mathrm{p}=0,2972$ ) (Figura 2.4C). Já a remoção de sardinha está significativamente ligada ao tipo de habitat (GLM, $\mathrm{F}_{3,62}=9,1307, \mathrm{p}<0,001$ ), afinal, apenas na soja há uma remoção menor de biomassa de sardinha em comparação a todos os outros sistemas $(\mathrm{p}<0,001)$. Entre agricultura orgânica, pastagem e vegetação nativa os valores de biomassa removida de sardinha não apresentaram diferenças $(p>0,05)$.

\section{Influência da riqueza de formigas e biomassa da fauna}

A correlação mais forte encontrada neste estudo é entre a riqueza de formiga e sua biomassa $(r=0,68, p<0,001)$ (Figura 2.5). Já para as biomassas removidas de recursos, encontramos que: (a) para remoção de semente não existe correlação com nenhuma das variáveis apresentadas ( $>0,05)$; (b) as correlações detectadas para os recursos de sardinha e banana foram relativamente fracas; e (c) para remoção de biomassa de sardinha foi encontrada uma correlação com a riqueza de formigas $(r=0,54, p<0,001)$ (Figura 2.6). Entretanto, excluindo os dados da soja (Figura 2.7), para a remoção de biomassa de banana surge uma correlação desta com a riqueza de formigas $(\mathrm{r}=0,32, \mathrm{p}=0,02)$. 
Influência da composição de espécies

Quanto à composição de espécies de formigas analisadas nas CCAs, os modelos foram significativos (ANOVA.CCA completa $\mathrm{F}_{8,57}=1,7478, \mathrm{p}<0,001$ e ANOVA.CCA apenas para espécies abundantes $\mathrm{F}_{8,57}=3,5721, \mathrm{p}<0,001$ ), assim como os dois primeiros eixos que formam as figuras 2.8 e 2.9. Também não foi detectado multicolinearidade entre as variáveis dos modelos (maior VIF foi igual a 2,25). Para os dois modelos, o fator tipo de uso da terra afeta a composição de espécies (para a variável uso da terra ANOVA.CCA completa $F_{3,57}=2,7151, p<0,001$ e ANOVA.CCA apenas para espécies abundantes $\left.\mathrm{F}_{3,57}=7,7473, \mathrm{p}<0,001\right)$. Mas apenas para a análise das espécies abundates é que a riqueza influência significativamente na composição das espécies (ANOVA.CCA para espécies abundantes $\mathrm{F}_{8,57}=1,5914, \mathrm{p}=0,044$ ). 


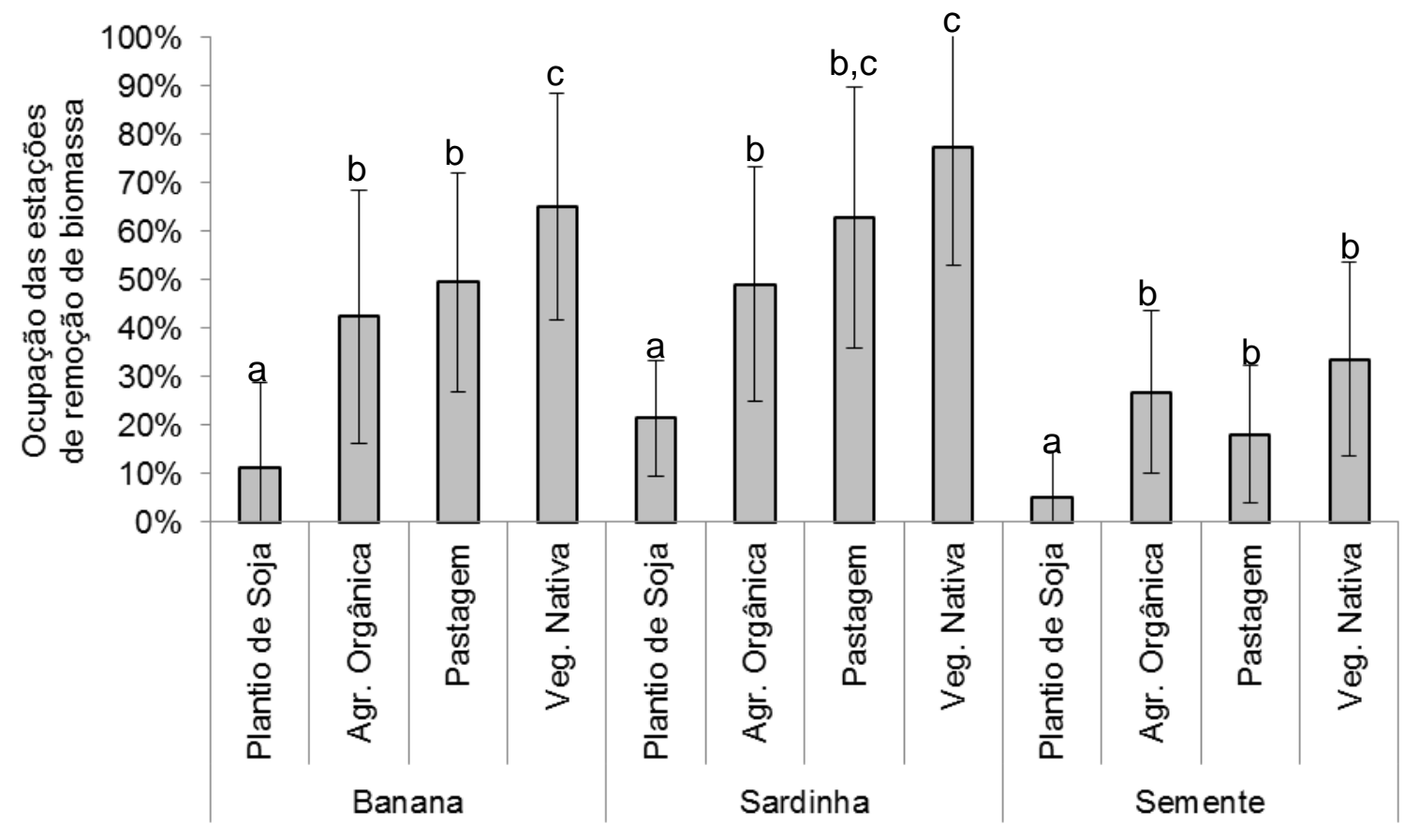

Figura 2.3. Proporção de estações de remoção de biomassa ocupadas por formigas nas coletas de 2013 e 2014 no Distrito Federal. Letras diferentes significam diferenças significativas $(p<0,05)$ entre as proporções de ocupação dentro de cada tipo de recurso, barras representam o desvio padrão. 

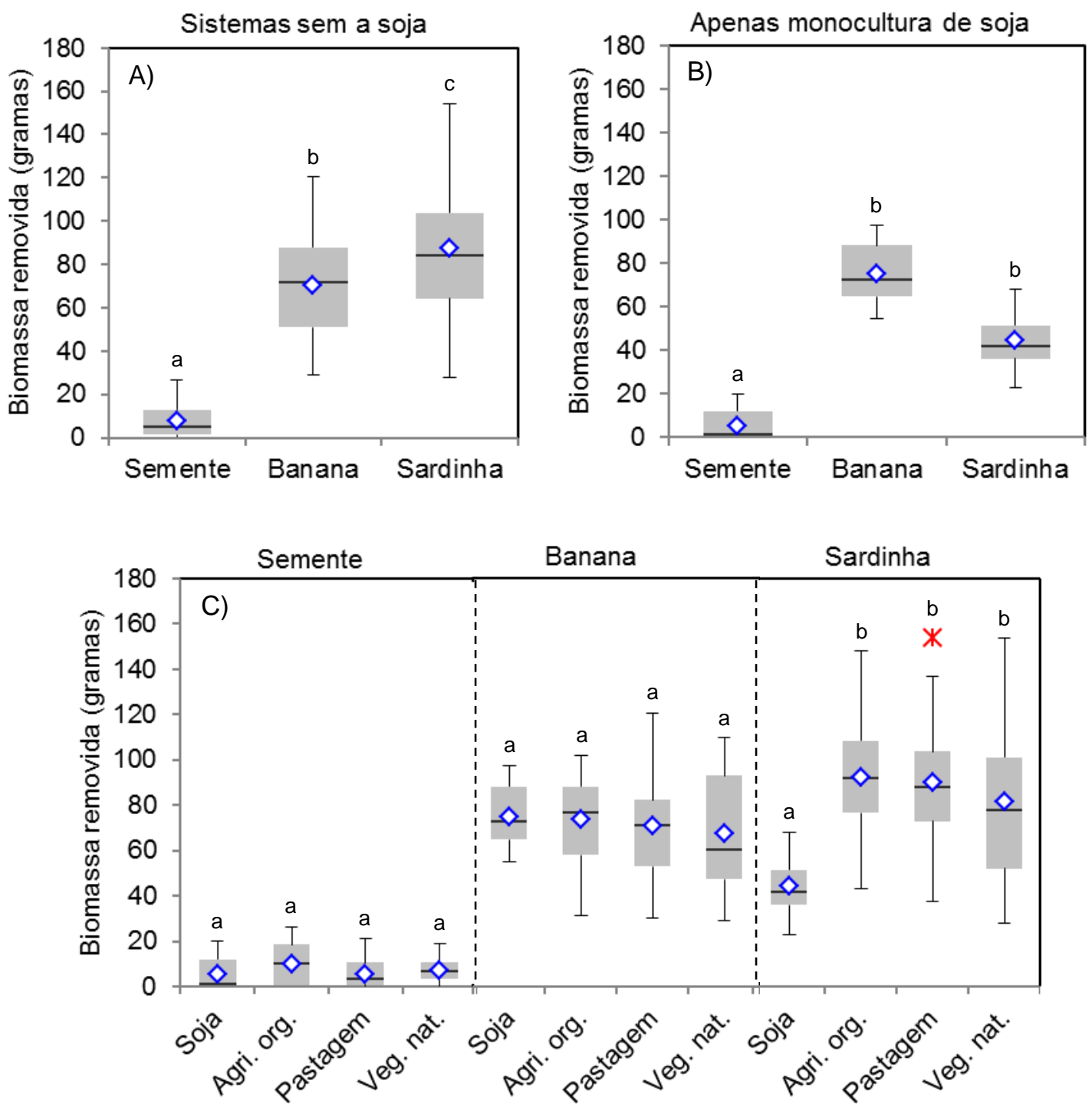

Figura 2.4. Biomassa removida para os diferentes tipos de recurso sem contabilizar a soja (A), apenas para a soja (B) e para os diferentes tipos de habitats (C), nos experimentos realizados de 2013 a 2014, no Distrito Federal. Letras diferentes retratam diferenças significativas $(\mathrm{p}<0,05)$. Retângulos cinzas contemplam do $1^{\circ}$ ao $3^{\circ}$ quartil, a linha horizontal dentro do retângulo representa a mediana, diamante em azul representa a média e asterico em vermelho um outlier. 


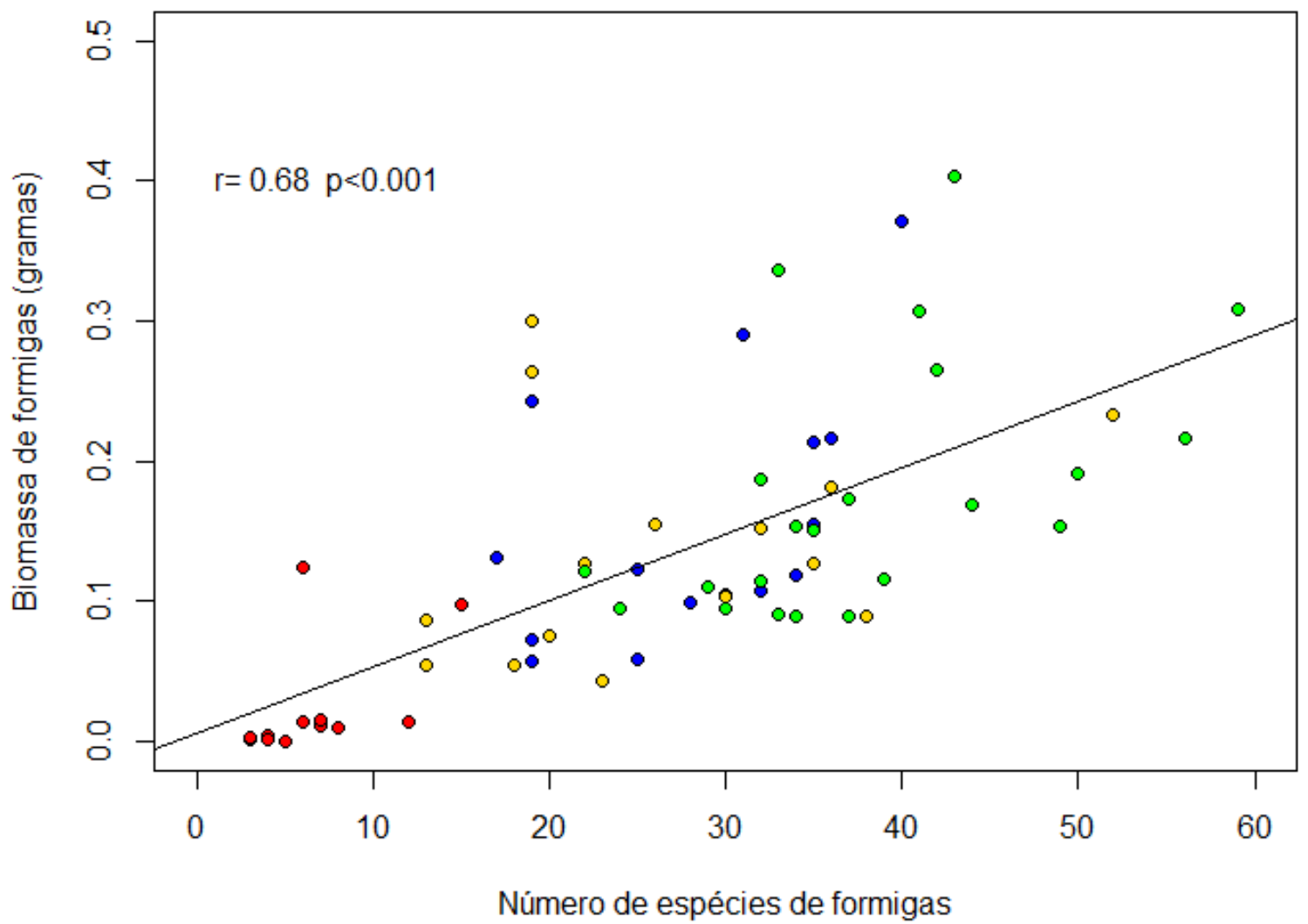

Figura 2.5. Correlação de Pearson entre número de espécies de formigas e a biomassa de formigas capturadas nas armadilhas de queda em cada localidade. Pontos coloridos indicam o habitat coletado no ano de 2013 e 2014 no Distrito Federal: (vermelho) soja, (azul) pastagem, (amarelo) agricultura orgânica e (verde) vegetação nativa. 


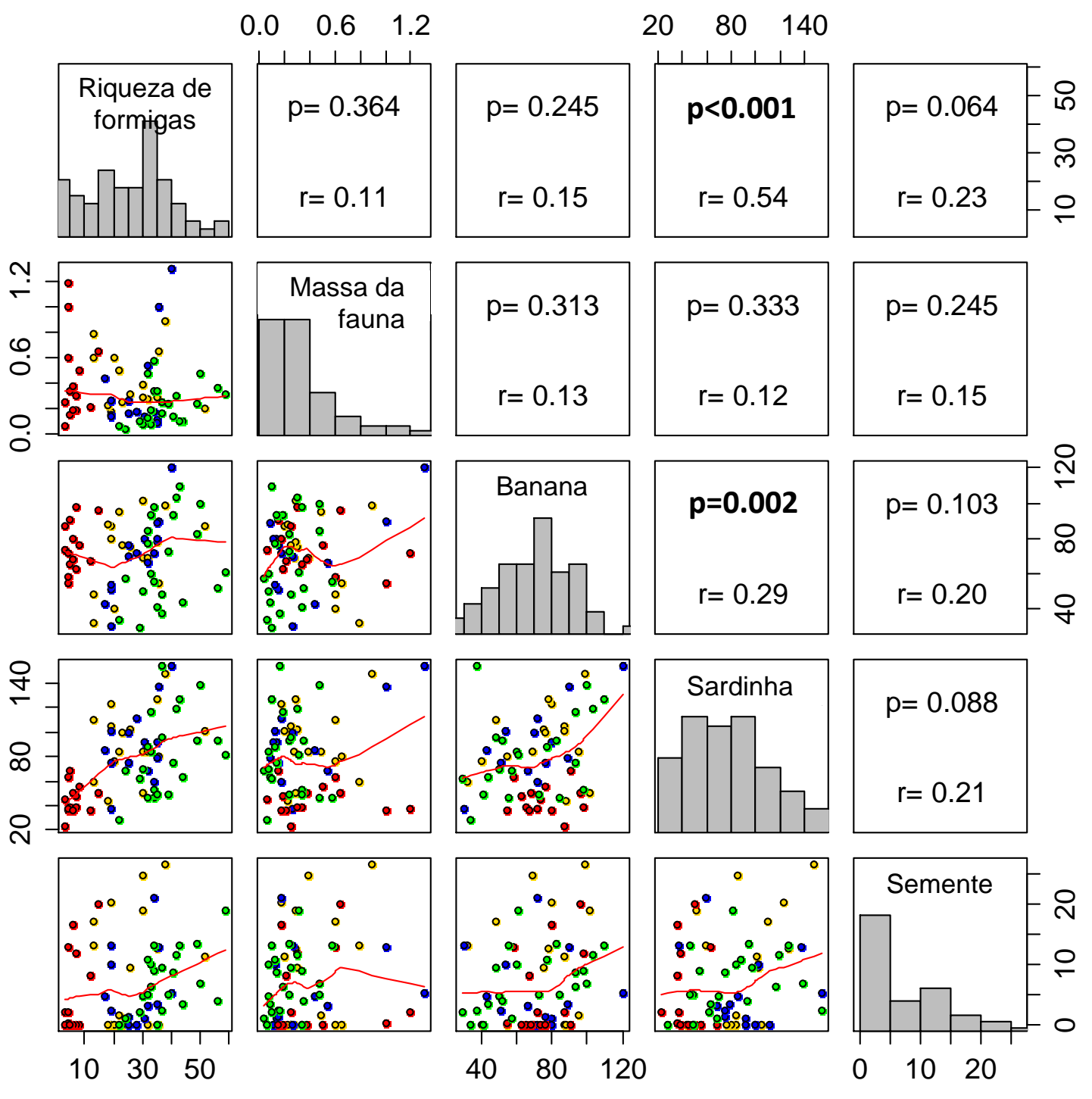

Figura 2.6. Matriz de correlação de Pearson entre número de espécies de formigas, massa da macrofauna (exceto formigas) e biomassa removida de banana, sardinha e semente. Os valores de correlação significativos $(\mathrm{p}<0,05)$ são indicados em negrito. Linha em vermelho representa a tendência não linear de dispersão dos dados. Pontos coloridos indicam o habitat coletado no ano de 2013 e 2014 no Distrito Federal: (vermelho) soja, (azul) pastagem, (amarelo) agricultura orgânica e (verde) vegetação nativa. 


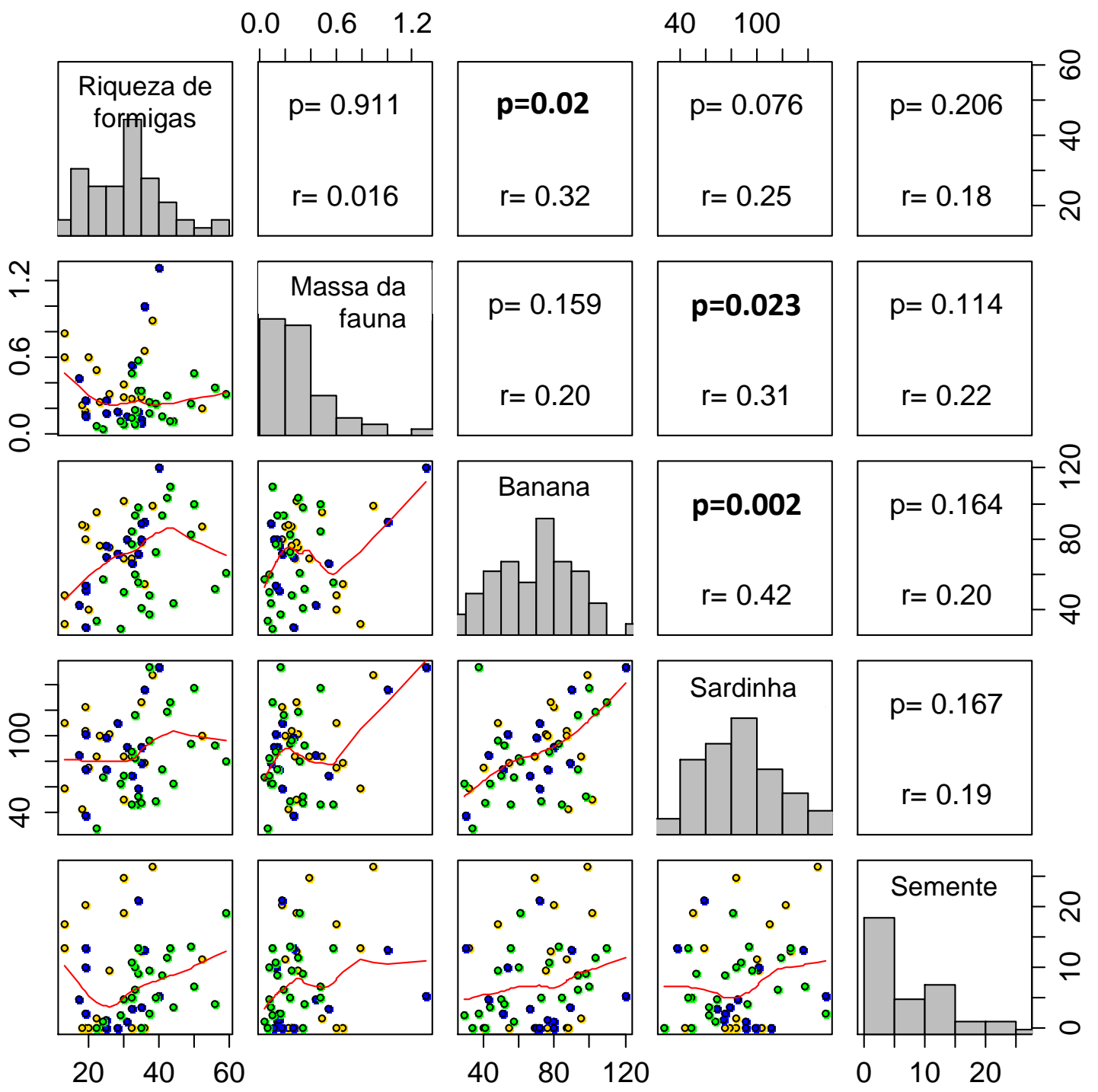

Figura 2.7. Matriz de correlação Pearson (neste caso, sem os dados da soja) entre número de espécies de formigas, massa da macrofauna (exceto formigas) e biomassa removida de banana, sardinha e semente. Os valores de correlação significativos $(\mathrm{p}<0,05)$ são indicados em negrito. Linha em vermelho representa a tendência não linear de dispersão dos dados. Pontos coloridos indicam o habitat coletado no ano de 2013 e 2014 no Distrito Federal: (azul) pastagem, (amarelo) agricultura orgânica e (verde) vegetação nativa. 


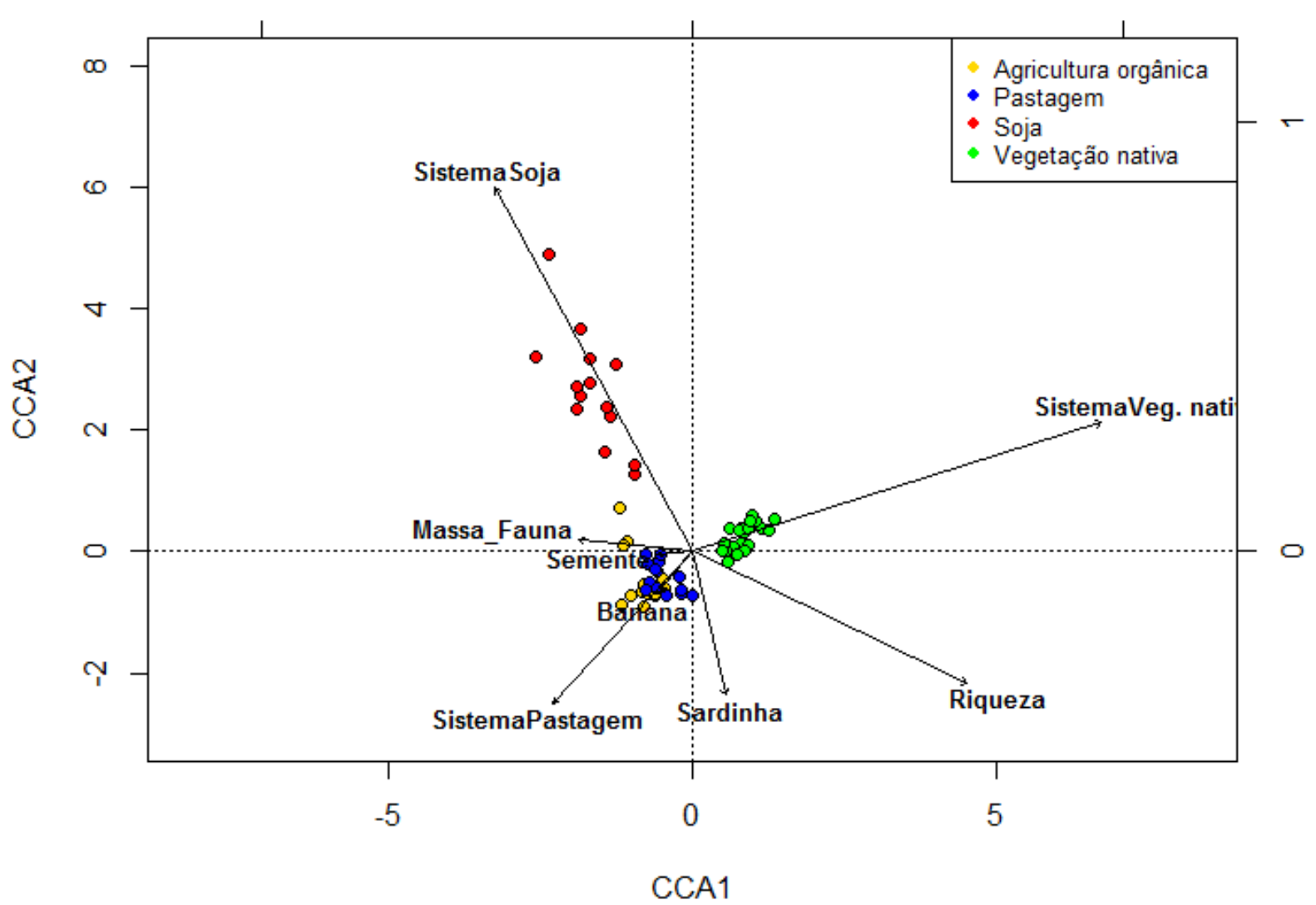

Figura 2.8. Análise de correspondência canônica que verifica a influência de variáveis sobre a composição de espécies de formigas, coletadas no ano de 2013 e 2014 no Distrito Federal. A única variável significativa nesta análise foi o sistema em que as formigas foram coletadas $\left(F_{3,57}=2,7151, p<0,001\right)$. A posição das espécies nesta imagem foi suprimida para facilitar a visualização dos dados. 


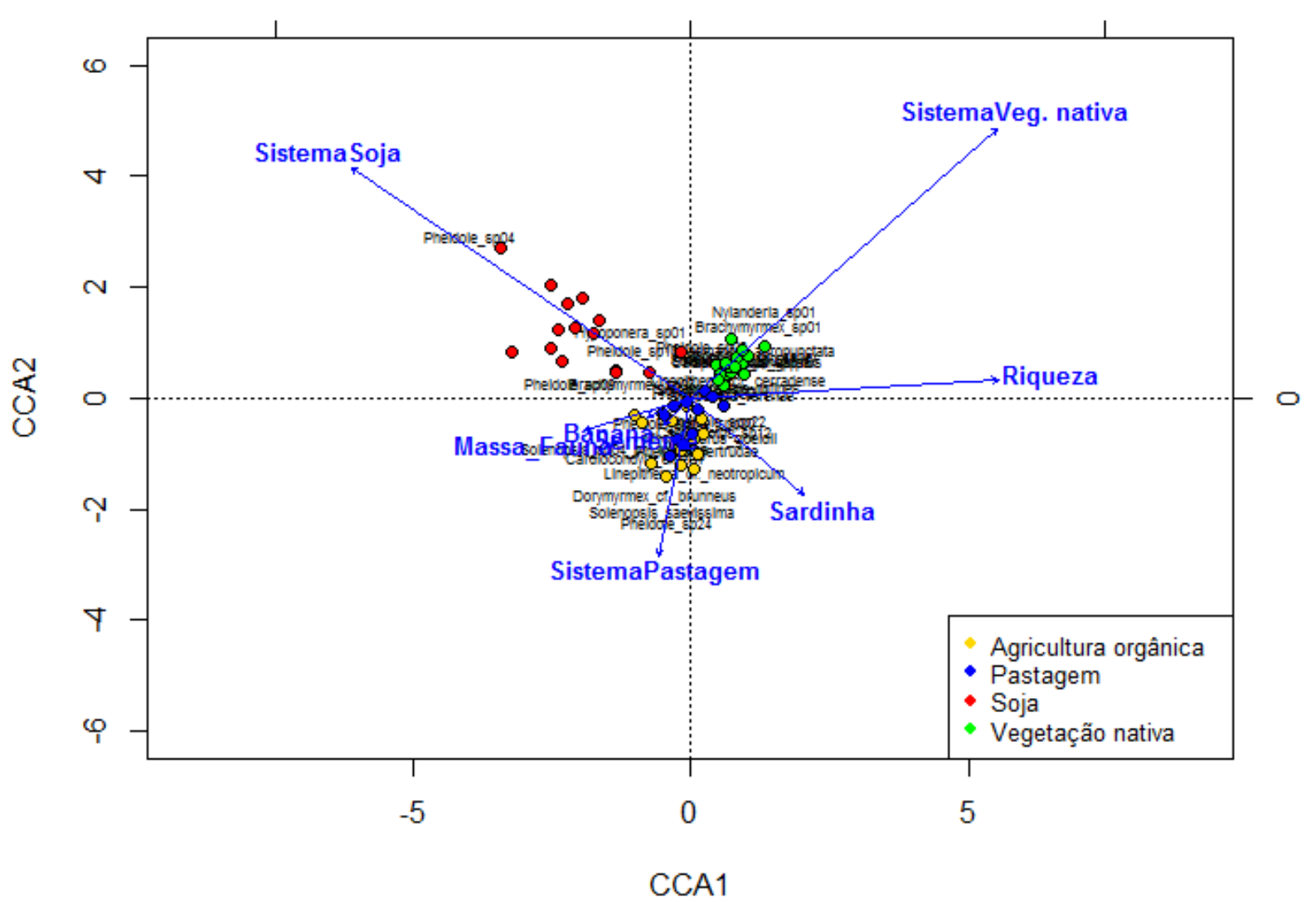

Figura 2.9. Análise de correspondência canônica apenas das espécies de formigas que ocorreram mais de 30 vezes, que verifica a influência de variáveis sobre a composição de espécies de formigas coletadas no ano de 2013 e 2014 no Distrito Federal. As variáveis significativas nesta análise foram o sistema em que as formigas foram coletadas $\left(\mathrm{F}_{3,57}=7,7406, \mathrm{p}<0,001\right)$ e a riqueza $\left(\mathrm{F}_{8,57}=1,5914, \mathrm{p}=0,044\right)$. 


\section{Discussão}

Ocorrência de formigas nas estações de remoção de biomassa

No Cerrado, as formigas são o grupo dominante sobre a superfície do solo, monopolizando os recursos por elas utilizados. Prova disso é o número de estações de remoção de biomassa, ocupadas por formigas após 24 horas (Figura 2.3), que foram encontradas e monopolizadas por elas, logo nos primeiros minutos. No entanto, detectou-se um efeito do tipo de uso da terra, pois os agrossistemas e, em especial, os plantios de monocultura de soja apresentaram uma menor proporção de estações ocupadas após 24 horas em comparação com as áreas de vegetação nativa.

A existência de estações de remoção de biomassa com alimento, mas sem a presença de formigas, está ligada a três fatores: a saciedade, o territorialismo e/ou a ausência de formigas. De modo geral, após as 24 horas de experimento em campo, é provável que para algumas colônias de formigas tenha ocorrido a saciedade do consumo de alimento (sensu Galen 2005). Além disso, devido ao comportamento territorialista das formigas, é pouco provável que formigas venham de longe remover estas iscas (Hölldobler \& Lumsden 1980). Sendo assim, a ausência de formigas dentro das estações de remoção de biomassa, refletem a quantidade de formigas no local.

\section{Taxas de remoção de biomassa entre os tipos de recursos}

Vários estudos apontam que formigas apresentam preferência alimentar de acordo com o nutriente mais limitante naquele ambiente (Kaspariz \& Yanovlak 2001; Bihn et al. 2008; Kaspari et al. 2008; Vieira \& Vasconcelos 2014). Neste estudo, nota-se que a sardinha foi a isca com maior consumo por formigas, sendo esse tipo de isca, amplamente utilizado como atrativo para formigas no Cerrado (e.g. Lopes \& Vasconcelos 2008) e em outros biomas, 
como Mata Atlântica (e.g. Diehl et al. 2004), Caatinga (e.g. Ulysséa \& Brandão 2013) e Amazônia (e.g. Vasconcelos et al. 2008). Logo, nossos resultados contrariam o estudo de Vieira \& Vasconcelos (2014), também realizado no Cerrado (mas utilizando iscas diferentes), no qual formigas de solo demostram preferência por alimentos que contenham sacarose, enquanto são as formigas arborícolas as que utilizam mais recurso rico em sódio (abundante no recurso sardinha), resultados similares ao encontrado por Kaspariz \& Yanovlak (2001), utilizando carne e açucar. Segundo esses estudos, isso ocorre aparentemente devido ao hábito alimentar das formigas, já que espécies no solo raramente teriam contato com alimentos açucarados, mais comuns na vegetação arbórea (Vieira \& Vasconcelos 2014).

Os alimentos simulando organismos animais (sardinha), em geral, foram os que as formigas mais removeram ao final das 24 horas (com exceção dos plantios de soja). Segundo Fisher et al. (2005), o recurso alimentar consumido pelos adultos e larvas de formigas são diferentes. Os recursos proteicos e com lipídios capturados pelos forrageadores são preferencialmente utilizados para alimentar as larvas no ninho e garantir o crescimento da colônia. Já os alimentos ricos em açúcares e carboidratos são geralmente utilizados pelas operárias para os gastos diários de energia (Fisher et al. 2005). Esse pode ser o fator determinante para uma maior remoção de sardinha e não das outras iscas.

Os valores removidos de biomassa de sardinha e de banana foram próximos entre si, o que demonstra que esta pode ser um importante complemento alimentar para a mirmecofauna do solo, como propôs Vieira \& Vasconcelos (2014). Logo, essa proximidade também é um claro indicativo de que, assim como relatado por Hunter (2009), a "promiscuidade trófica" nos artrópodes parece ser muito mais ampla do que imaginado a priori pelos pesquisadores. Além de ser uma possível explicação para o paradoxo formiga-biomassa de Tobin (1994), no qual ele discute que a biomassa de formigas em alguns ecossistemas é tão grande que apenas 
a alimentação via predação de outros animais, não é capaz de explicar a quantidade de formigas observada.

No entanto, verifica-se também que, apesar de estudos indicarem que formigas têm um importante papel na predação e dispersão de sementes (Ferreira et al. 2011), estas parecem ser um alimento, relativamente, de baixa importância. Isso se confirma mesmo também tendo capturado espécies que consomem predominantemente sementes, como Pogonomyrmex naegelii (Belchior et al. 2012).

Um último fato que também pode influênciar a taxa de remoção de biomassa dos diferentes tipos de recurso é o comportamento durante a remoção. Nas observações de campo, notou-se que a isca de sardinha era removida carregando-se os pedaços individualmente ou em grupo, quando estes eram muito grandes. Já para banana, assim como sardinha, ocorreu o recrutamento, geralmente com a monopolização do recurso, mas a remoção deste era sempre feita de forma individual e as formigas aparentemente sugavam a banana ao invés de carregar pedaços entre as mandíbulas. Já para sementes, não há recrutamento e nem monopolização, isso provavelmente devido ao fato de que esse tipo de recurso na natureza não tem ocorrência agregada (por isso, não requer o recrutamento) e também não é um recurso raro.

\section{Taxas de remoção de biomassa entre os habitats}

Tanto para iscas de banana como para de semente não foram encontradas diferenças significativas nos valores removidos de biomassa entre os distintos tipos de habitats. Para semente isso provavelmente se deve ao fato de que o consumo desse alimento é muito reduzido, se comparado a outros tipos de alimento. Nesses casos em que as diferenças podem ter magnitudes pequenas, uma metodologia com maior precisão, como contar o número de sementes, pode encontrar tais diferenças (como a realizada por Ferreira et al. 2011). Mas com 
nossos dados não se constata nenhum fator que explique a remoção de semente, pois, para 36 das 67 localidades analisadas, a remoção de sementes foi menor do que cinco gramas.

Já para banana, os valores removidos foram independentes do tipo de habitat. Porém, levando em consideração que os monocultivos de soja praticamente não têm formigas (em número de espécies e massa), comparativamente aos outros habitats, é ilógico admitir que esta remoção no habitat soja tenha sido realizada por formigas. Além disso, sabe-se que muitas das pragas de soja, em especial lagartas da família Noctuidae, alimentam-se à noite (Lingren et al. 1977; Gregory Jr 1989), por isso supomos a existência de um efeito de substituição por uma espécie ou grupo de espécies que desempenhe função similar às formigas de remoção de biomassa de banana. Existe a suposição também de que baratas (Ordem: Blattodea) podem ser um importante consumidor das iscas de banana nas áreas de soja. Mas, como não se capturou nenhum invertebrado que justifique essa afirmação, já que poucas moscas, mariposas e gafanhotos foram encontrados no final do experimento, dentro das estações de remoção de biomassa na soja, essa suposição é apenas uma hipótese. Isso porque esta se assemelha ao resultado descrito por Hooper et al. (2005), o qual afirma que, na ausência da espécie ou grupo de espécies que desempenha determinada função do ecossistema, uma segunda espécie ou grupo de espécies pode assumir a função destas.

\section{Influência da riqueza de formigas e biomassa da fauna}

Como discutido, a soja possivelmente é um habitat no qual a remoção de biomassa de banana está sendo realizada por outro grupo de invertebrados. Por isso, excluindo a soja da matriz de correlação (Figura 2.7), observa-se que existe uma correlação entre a riqueza de formigas $(\mathrm{r}=0,32)$ com a biomassa removida de banana. $\mathrm{O}$ mesmo padrão, só que mais forte, também foi encontrado para a biomassa removida de sardinha (Figura 2.6). Os dados também demonstram que essa riqueza de formigas esta correlacionada positivamente com a biomassa 
de formigas (Figura 2.5). Três hipóteses explicam o porquê destes fatores afetarem a função do ecossistema de remoção de biomassa. Primeiramente, em relação à riqueza de formigas, sugere-se a hipótese do efeito amostral, que prediz que, quanto maior o número de espécies, mais provável é que alguma destas desempenhe um papel importante nessa função (Hopper et al. 2005; Balvanera et al. 2006). Existe também a hipótese da complementariedade, a qual intui que a soma quantitativa do papel de cada nova espécie encontrada aumenta na mesma proporção a função a elas correlacionadas (Tscharntke et al. 2005). Contudo, Loreau et al. (2008) discutem que tanto o efeito amostral como a complementariedade não são mutuamente exclusivos, portanto, essas duas hipóteses provavelmente afetam a remoção de biomassa ao mesmo tempo. Por último, a respeito da biomassa de formigas, há a hipótese de mais indivíduos (Srivastava \& Lawton 1998), segundo a qual quanto mais recurso, maior a quantidade de consumidores (neste caso, influenciando a biomassa removida). Em estudos similares, Fayle et al. (2011) também encontraram uma relação positiva entre riqueza de formiga e taxa de remoção de biomassa, porém, Gray et al. (2015) não encontrou influência da riqueza e nem do recrutamento de formigas sobre as taxas de remoção de isca. Neste estudo de Gray et al. (2015) o que influenciou os valores de remoção de biomassa, foram a quantidade de isca que as formigas conseguiam transportar.

\section{Influência da composição de espécies}

As correlações encontradas foram de moderado a fracas, com $r<0,7$, muitas vezes valores característicos de experimentos realizados em condições reais, mas que também pode indicar a potencial existência de outras variáveis explicativas. Uma dessas potenciais variáveis, que aumentam o erro, provavelmente, é a identidade das espécies de formigas que realizam esta função de remoção de biomassa. Essa questão da identidade tabém é abordada por Del-Claro \& Marquis (2015), Armbrecht \& Gallego (2007) e Gonthier et al. (2013), de 
acordo com os quais a identidade da espécie tem grande relevância para determinar os níveis de predação.

De modo similar, apesar da análise de correspondência canônica indicar que somente o tipo de habitat ou a riqueza de espécies têm relação com a composição da assembleia de formigas, é inegável que algumas espécies podem desempenhar o papel de remoção de biomassa melhor que outras. Como exemplo disso pode-se citar as espécies do gênero Brachymyrmex, todas de tamanho diminuto (em média 1,25 mm) que, independentemente do tamanho da colônia, dificilmente conseguiriam remover quantidades significativas das iscas disponibilizadas. No entanto, formigas do gênero Ectatomma (em média $130 \mathrm{~mm}$ ) conseguem remover pedaços relativamente grandes das iscas de uma única vez e ter potencialmente grande influência sobre o total de biomassa removida. Assim, dentre essas formigas citadas, também é importante destacar o papel das de tamanho intermediário, que têm o comportamento de recrutar, podendo remover grandes quantidades das iscas devido ao número de indivíduos que trabalham em conjunto, como algumas espécies do gênero Pheidole, Solenopsis e as formigas de correição.

As três espécies de formigas mais encontradas dentro das estações de remoção de biomassa após as 24 horas em campo, foram Pheidole sp. 01, Pheidole gertrudae (Forel, 1886) e Solenopsis saevissima (Smith, F., 1855) (Anexo IV), todas pertencentes ao grupo funcional descrito anteriormente no Capítulo I como generalistas dominates. Além destas, em eventos esporádicos, estas iscas foram encontradas por formigas de correição, um grupo que abrange os gêneros Eciton, Labidus, Neivamyrmex e Nomamyrmex, que são espécies nômades (sem colônia fixa), as quais podem ter colônias relativamente grandes e são reconhecidamente vorazes (Palacio 2003). Em decorrência de eventos como esses, duas localidades tiveram de ser excluídas das análises estatísticas - o ponto $\mathrm{VN}-18$ e o $\mathrm{VN}-21-$, pois a ocorrência de correição da espécie Labidus praedator (Smith, F., 1858) foi tão grande que a massa 
desidratada de formigas capturadas em cada um desses pontos foi mais de 7,5 vezes maior que o terceiro ponto com mais formigas. Isso levou a ocorrer, nesses pontos específicos, praticamente a remoção total de biomassa de sardinha disponível, cerca de $237 \mathrm{~g}$ e $224 \mathrm{~g}$.

Em vista disso, sugere-se que futuros estudos usem uma abordagem que leve em consideração a abundância espécie/específica. Assim como já indicado, a presença abundante de L. praedator tem grandes efeitos sobre a biomassa removida, mas essa espécie também foi capturada em outras localidades e, provavelmente devido a uma abundância menor de indivíduos dela nessas localidades, não ocorreu uma remoção tão intensa como a da amostrada nas localidades VN-18 e VN-21. 


\section{Conclusão}

As formigas têm preferência por remover iscas de sardinha (que simula uma dieta baseada em organismos animais), em média, $20 \%$ a mais do que de banana, recurso que simula apêndices atrativos de sementes e frutas do Cerrado. Já as sementes, relativamente às outras duas iscas, praticamente não foram removidas. Isso evidencia que formigas selecionam os recursos preferenciais e, ao mesmo tempo, possuem uma grande "promiscuidade trófica" (Hunter 2009).

Foi detectado também uma capacidade de resistência das funções do ecossistema, frente as mudanças no uso da terra. Isso, porque apenas nas áreas de soja detectamos uma redução significativa na remoção de biomassa de sardinha. Mais especificamente foi encontrado que a riqueza de formigas está correlacionada à função do ecossistema de remoção de biomassa orgânica (sensu Fayle et al. 2011). E, assim como descritos nas revisões feitas por Hopper et al. (2005), Cardinale et al. (2006) e Allan et al. (2013), também encontrou-se que a intensificação da agricultura pode ou não levar à redução de determinada função do ecossistema, dependendo das características da função citada e do tipo de uso da terra. 


\section{Capítulo III - Contribuição das formigas (Hymenoptera: Formicidae) para a predação de ovos de lagarta em sistemas orgânicos de produção de hortaliças}

\section{Resumo}

Devido à crescente demanda por alimentos ecológicos e sem agrotóxicos, tem ocorrido um aumento no número de agricultores orgânicos. No entanto, para viabilizar ou aumentar a eficiência da produção de orgâncicos, se faz necessário uma série de conhecimentos. Dentre estes se incluem a identificação das espécies que realizam o controle biológico das pragas agrícolas e qual a influência da paisagem. Já é consenso que Coleoptera, Araneae, Diptera e Hemiptera são os principais predadores nos sistemas orgânicos, mas, no que diz respeito ao Cerrado, há poucos estudos sobre a taxa de predação exercida por Formicidae (formigas). Por isso, este estudo avaliou as taxas de predação de ovos de lagarta e como essas taxas são influenciadas pelo tipo de uso da terra no entorno das propriedades. Para isso, foi realizado um experimento em 18 áreas de agricultura orgânica no Distrito Federal envolvendo testes de predação de ovos de Anticarsia gemmatalis e amostragem da fauna. Este estudo mostrou que formigas são capazes de reduzir a população de ovos em $26,8 \%$ ao dia, enquanto outros táxons de predadores, representados principalmente por Coleoptera (das famílias Coccinellidae e Staphylinidae), removeram 13\% dos ovos. Verificou-se também que as formigas do gênero Linepithema, Dorymyrmex e Camponotus foram as mais frequentes, porém os gêneros Pheidole e Solenopis são as com maior poder de recrutamento. A proporção de área plantada num raio de 500 metros, além da interação das outras categorias da paisagem entre si, tem uma pequena influência para a predação, apenas quando os predadores não são formigas. Para a predação realizada por predadores em geral, incluindo formigas, ou apenas por formigas, a paisagem não tem influência. 


\section{Introdução}

Um dos oito objetivos do milênio lançados pela ONU é garantir o desenvolvimento sustentável (UNPD 2015). Isso implica em mudar a forma como se produz alimento atualmente, pois o que ococorre hoje é, em sua maioria, o processo de intensificação do uso da terra para aumentar a produtividade, o que consequentemente amplifica os efeitos negativos sobre a biodiversidade (e.g. Flynn et al. 2010; Jones et al. 2003). Por outro lado, aumentar a intensificação do uso da terra não é a única maneira de aumentar a produtividade.

Em uma revisão, Tscharntke et al. (2005) apontaram que a intensificação do uso da terra significa a conversão de sistemas naturais complexos em direção a ecossistemas manejados e simplificados, dependentes de insumos artificiais, da mecanização e da frequente intervenção humana. Aliado à consequente perda de espécies pela intensificação, encontra-se a redução nos serviços ecológicos, incluindo a polinização (Brittain \& Potts 2011), controle biológico (Langellotto \& Denno 2004), entre outros, o que aumenta ainda mais a dependência destes sistemas em relação à intervenção humana. Porém, existem alternativas que reduzem esse impacto, como a produção orgânica (Winqvist et al. 2011), apesar de exitirem algumas incertezas quanto a seus reais benefícios ambientais (Hole et al. 2005). Nesse tipo de produção agrícola, destaca-se a produção de hortaliças orgânicas, que tem uma "pegada ecológica" menor do que a produção de grãos e carne (Wackernagel et al. 1999) e ainda com o benefício de estar associado a alimentos mais saudáveis, devido a não utilização de agrotóxicos (e.g. Chrisman et al. 2009).

No Brasil $85 \%$ do alimento consumido internamente é produzido por agricultores familiares, em áreas de, no máximo, quatro módulos fiscais e nas quais se cultiva mais do que uma cultura comercial (IPD 2010). Com o intuito de agregar ainda mais valor ao seu produto, muito desses agricultores têm migrado para o sistema orgânico, cujo mercado, só em 2015, 
cresceu 35\%, atingindo R $\$ 2,5$ bilhões em produtos comercializados (BioFach 2016; MAPA 2016c).

Mas essa transição, da agricultura convencional para a orgânica, exige mudanças de manejo que envolvem certos riscos, pois a produção orgânica depende da restauração e conservação de diferentes serviços ecológicos, os quais viabilizam uma produção agrícola sustentável (Sujii et al. 2010). Em vista disso, uma das principais demandas dos agricultores está relacionada com os problemas fitossanitários com insetos praga, que não podem ser controlados com agrotóxicos nos sistemas orgânicos, por isso, recorre-se ao controle biológico (Landis et al. 2000). Por exemplo, o uso de insetos parasitoides de pragas agrícolas já é uma ferramenta utilizada comercialmente, na qual o parasitoide efetivamente regula o tamanho populacional de seus hospedeiros (Parra \& Zucchi 2004).

Para incrementar o controle biológico e para não favorecer insetos praga, a técnica mais amplamente utilizada e pesquisada nas últimas décadas tem sido o aumento da diversidade vegetal em escalas, as quais variam desde o talhão de cultivo até a diversidade da paisagem agrícola (Gurr et al. 2003; Zhender et al. 2004; Sujii et al. 2010; Letourneau et al. 2011). O aumento da diversidade vegetal no primeiro nível trófico, em geral, tende a ter um efeito positivo nos inimigos naturais e um efeito negativo nos herbívoros (Haddad et al. 2009; Letourneau et al. 2011). Em contrapartida, o aumento da diversidade vegetal gera um aumento da complexidade do habitat, o que diminui a chance de exclusão dos insetos praga deste ambiente, mas, ao mesmo tempo, diminui a probabilidade de explosão populacional destes insetos (Karban et al. 2013).

No que diz respeito à paisagem de zonas agrícolas, estas têm sido estudadas para explicar o porquê de algumas áreas abrigarem mais predadores e/ou possuírem níveis maiores de predação sobre insetos praga. Até agora, nesses estudos tem sido percebido que paisagens agrícolas, onde há um aumento da complexidade ou da proporção de áreas nativas, têm mais 
espécies (revisado por Tscharntke et al. 2005) e/ou maiores taxas de predação e produtividade (Leiere et al. 2015; Balzan et al. 2016), apesar desse efeito estar ligado também ao táxon (Lemessa et al. 2015). Porém, há alguns estudos que não detectaram efeito da paisagem (e.g. Silva \& Marco Jr 2014).

Comumente os organismos benéficos mais estudados dentro das áreas orgânicas são os coleópteros da Família Coccinellidae, popularmente conhecidos como joaninhas (e.g. Harterreiten-Souza et al. 2012; Togni et al. 2016), e os micro-hymenópteras (e.g. Vieira et al. 2013). Porém as formigas, além de comportamento predatório e organização eusocial, intituladas até de superorganismo (Hölldobler \& Wilson 2009), possuem todas as prerrogativas para serem consideradas agentes de controle biológico. Offenberg et al. (2015), em uma revisão, afirmaram que formigas do gênero Oecophilla reduzem a abundância das pragas e de seus danos e aumentam os ganhos financeiros em diversos cultivos. A eficiência delas foi considerada até maior do que a do uso de pesticidas químicos e com a vantagem de ter baixo custo.

Antagonicamente, algumas espécies de formigas podem causar prejuízo aos agricultores. Um exemplo comum disso, é a associação mutualística de várias espécies de formigas com afídeos, na qual a planta hospedeira pode ou não ser prejudicada (revisado por Styrsk \& Eubanks 2007). Além disso, formigas do gênero Atta e Acromyrmex, que cortam folhas para cultivar fungos dos quais se alimentam (Fernández 2003), são classificadas como importantes pragas agrícolas. E por serem pragas que demandam constante monitoramento e com grande potencial de dano econômico (Hernández \& Jaffé 1995; Zanetti et al. 2014) acabam sendo associadas pelos agricultores a todas as outras espécies de formigas, incluindo as outras 2.000 espécies que se estima existir no Brasil (Baccaro et al. 2015).

Com base nestas informações, buscou-se avaliar qual a contribuição das formigas para o controle biológico natural de insetos herbívoros em agrossistemas e determinar quais são os 
fatores mais importantes que influenciam as taxas de predação nas áreas orgânicas. Especificamente, procurou-se determinar: (1) se formigas são um grupo que efetivamente reduz a população de herbívoros através da predação de ovos de lagarta; e (2) se estas taxas de predação são explicadas pela abundância de predadores (incluindo táxons diferentes das formigas), ocorrência de formigas e/ou uso da terra no entorno e dentro das propriedades. 


\section{Metodologia}

\section{Áreas de estudo}

As coletas foram realizadas dentro do Distrito Federal nos meses de junho e agosto de 2015, em 18 áreas de produção orgânica de hortaliças, chamadas de localidades (Figura 3.1 e Tabela 3.1). A distância mínima entre as localidades foi de $1,5 \mathrm{~km}$, sendo que todas as áreas pertencem a agricultores diferentes, com exceção das localidades amostradas Malunga 1 e Malunga 2. As culturas plantadas em cada localidade são muito variadas, mas incluem principalmente: alface, couve, cebolinha, salsinha, berinjela, quiabo, jiló, cenoura, cará, inhame, milho, abobrinha, tomate e pimentão. O método de cultivo também é muito variado, há localidades em que o talhão todo é de um único tipo de cultivo, outras em que cada linha de cultivo é de uma espécie diferente de hortaliça e, por último, algumas propriedades misturam, na mesma linha de cultivo, mais de um tipo de hortaliça. Há ainda o tipo de manejo agronômico que varia de uma propriedade para outra - como o tipo de adubação ou o uso de produtos naturais para combate às pragas -, sendo inviável avaliar como isso afeta o controle biológico pela falta de repetição ou gradiente de mudança entre as propriedades.

\section{Protocolo amostral}

Para medir as taxas de predação, foi elaborado um experimento com 24 horas de duração, para o qual foi desenvolvido um dispositivo (chamado de estaca de predação) que simula uma planta (Figura 3.2-A), neste eram disponibilizados ovos de Anticarsia gemmatalis (Hübner, 1818)(Lepidoptera: Noctuidae), um inseto praga de várias culturas (especialmente a soja), criado em laboratório, dentro da Embrapa Cenargen, para ser utilizado em pesquisas. Esse dispositivo, com altura de 25 a $30 \mathrm{~cm}$, possui no topo seis "ramos", os quais seguram, nas pontas, retângulos de cartolina verde com aproximadamente 5 x $3 \mathrm{~cm}$, simulando folhas. 
Em cada um desses dispositivos existia: a) um ramo com uma folha com ovos, estes poderiam ser acessados por todos os possíveis predadores - esta folha foi chamada de tratamento; e b) um segundo ramo coberto por graxa de lítio (também conhecida como graxa branca), uma substância inodora, insolúvel e que impede o trânsito de animais não alados, principalmente formigas, e, na ponta deste ramo, uma folha, chamada de controle. Nesta segunda folha, também foram disponibilizados ovos, com o cuidado de, em cada estaca de predação, se colocar um número de ovos igual ou aproximado ao da cartela tratamento.

Devido a variação na densidade de ovos vindo da criação de A. gemmatalis, de acordo com a idade da colônia, o número de ovos disponibilizado em cada cartela variou de um a 90, para evitar que isso influencie os resultados, as estacas com baixa densidade ( $\leq 20$ ovos) foram alternadas com as de alta densidade (>20 ovos). Além disso, para simular as condições naturais de postura da maioria dos insetos praga, todos os ovos foram disponibilizados na página inferior da folha (voltados para baixo). Por fim, todas as cartelas, antes de irem a campo, tiveram o número de ovos contados e escrito na própria cartela (Figura 3.2-B). Portanto, pode-se determinar o número de ovos predados logo após a exposição da cartela em campo.

Além desses dispositivos para medir a predação, foram criadas estacas de amostragem, com a finalidade de amostrar a fauna que acessa as estacas de predação (Figura 3.2-C). Para isso, no topo de uma estaca, também com altura de 25 a $30 \mathrm{~cm}$, foi instalado um coletor universal de $100 \mathrm{ml}$, que em campo era preenchido até a metade de seu volume por água com detergente, na borda deste coletor foi derramada uma pequena quantidade de mel como atrativo. Além deste coletor, havia um ramo isolado por graxa de lítio, com um pedaço de cartolina verde, de 5 x $5 \mathrm{~cm}$, na sua ponta, o qual continha ao menos 20 ovos de $A$. gemmatalis e um pedaço de $5 \times 3 \mathrm{~cm}$ de armadilha adesiva amarela (Figura 3.2-D). Portanto, foi possível amostrar a fauna que sobe nas estacas, separando-se a que potencialmente acessa 
os ovos do tratamento (capturadas no coletor universal) ou do controle (capturadas na armadilha adesiva amarela).

\section{Desenho amostral}

Em cada localidade foram instaladas 60 estacas, sendo, 40 estacas de predação e 20 estacas de amostragem, totalizando 1.080 estacas nas 18 localidades. As estacas foram distribuídas seguindo as linhas de cultivo, a uma distância de sete metros uma da outra, e sendo sempre instaladas dentro do canteiro na seguinte ordem: estaca de amostragem, estaca de predação com cartelas contendo de 1 a 10 ovos, estaca de predação com cartelas contendo de 11 a 90 ovos e, assim, repetidamente. Portanto, foram instaladas, em cada localidade, 20 estacas de amostragem e 40 de predação, o que em linha reta teria um comprimento de 413 metros. No entanto, como os talhões geralmente são menores do que 40 metros de comprimento, uma nova linha era instalada paralelamente a esta, a sete metros de distância também. Por fim, tomou-se o cuidado de alternar as estacas de predação com baixas e com altas densidades de ovos, para evitar a concentração de ovos em determinada região da localidade e enviesar os resultados.

\section{Análise da paisagem}

Para realizar a categorização da paisagem e testar se esta influencia nas taxas de predação de ovos, foram utilizadas imagens disponibilizadas pela Codeplan (Companhia de Planejamento do Distrito Federal) no site ortofoto.mapa.codeplan.df.gov.br/demo/tms. Essas imagens foram capturadas por um VANT (veículo aéreo não tripulado), na mesma época da coleta (junho a agosto de 2015), e com uma resolução de $24 \mathrm{~cm}$. Em seguida, utilizando-se o programa ArcGIS 10.2.2 e ArcGIS Pro, foram mapeadas as áreas de: cobertura arbórea, construção, com plantio e sem plantio (Tabela 3.2). 
A cobertura arbórea foi definida como toda árvore ou conjunto de árvores, com diâmetro da copa superior a aproximadamente 4 metros nas imagens aéreas. As áreas de construção foram definidas como toda e qualquer área com edificações cobertas, cimentada ou asfaltada, incluindo açudes e estradas de terra bem definidas. Plantio foi determinado como a área plantada, a qual era identificada pela presença de linhas de plantio, geralmente apresentando formas geométricas que facilitaram sua identificação. No entanto, para essa classificação não foi possível determinar se esta área corresponde ao plantio com manejo convencional (usando agrotóxicos) ou ao orgânico. O restante, que foi chamado de sem plantio, basicamente, trata-se de pastagens, terrenos abandonados, potencialmente abrigando também áreas de vegetação nativa de campo ou de cerrado stricto sensu, com diversos graus de perturbação. Estas áreas não puderam ser classificadas de forma mais precisa porque estão distribuídas em um gradiente imperceptível pelas imagens aéreas.

Posteriormente a essa classificação, foi contabilizada a área em $\mathrm{m}^{2}$ de cada uma dessas categorias em "buffers" (ou seja, uma área) com raios de 1.000, 500, 250 e 125 metros, a partir do ponto central do conjunto de estacas instalado em cada localidade.

\section{Análise dos dados}

Todas as análises foram realizadas no programa R ( $\mathrm{R}$ Development Core Team 2008). Inicialmente foi aplicado um teste-t pareado, a fim de testar se as formigas efetivamente contribuem para o aumento das taxas de predação nas cartelas tratamento em relação ao controle, sendo a estaca o fator de pareamento. Logo após isso foram realizadas seleções de modelos para verificar se a paisagem influencia as taxas de predação de ovos. Nesta análise foram avaliadas três variáveis respostas: (1) o número de ovos predados no tratamento (predação realizada por formigas e outros predadores), (2) o número de ovos predados no controle (predação causada por artrópodes alados, excluindo-se formigas) e (3) o número de 
ovos predados no tratamento menos o controle (predação atribuída às formigas). As variáveis explanatórias foram as áreas das categorias da paisagem (cobertura arbórea, plantio, sem plantio e construção) e todas as possíveis interações entre duas destas variáveis. Para cada uma destas variáveis respostas foram construídos quatro modelos, um para cada buffer (1.000 m, $500 \mathrm{~m}, 250 \mathrm{~m}$ e $125 \mathrm{~m})$.

O procedimento de seleção de modelos foi realizado pelo processo "backward", utilizando a função $\mathrm{lm}$ do R (R Development Core Team 2008). Nesse processo começou-se com um modelo contendo todas as variáveis, e então a variável com maior $p$ foi removida, e novamente o modelo foi testado, até que restassem somente variáveis significativas. Além desse processo, a cada novo modelo com uma variável removida, este foi comparado ao anterior para verificar se ele sofre alterações significativas, utilizando-se, para isso, a função anova do R (R Development Core Team 2008). Por fim, para determinar o melhor modelo, foi aplicado o critério de Akaike, com a função AIC (Sakamoto et al. 1986) do R (R Development Core Team 2008).

Para determinar se o número de ovos predados está relacionado ao número de predadores, foram realizadas três regressões simples: (a) número de ovos predados no tratamento em função do número total de predadores; (b) número de ovos predados no controle em função dos predadores excluindo-se as formigas; e (c) número de ovos predados no tratamento menos o controle em função do número de ocorrência de formigas. É necessário esclarecer que, como Formicidae é um táxon social, o que leva a superestimava da abundância quando ocorre o recrutamento, apenas para esse grupo foi considerado como abundância o número de ocorrências registradas nos diferentes pontos (e.g. Vasconcelos et al. 2014). Além desses testes, como Formicidae foi o único táxon identificado até gênero, seguindo a chave de Bolton et al. (2007) e Fernández (2003), e posteriormente até morfotipo ou espécie, apenas para esse táxon foi realizada uma correlação entre ocorrência e riqueza. 


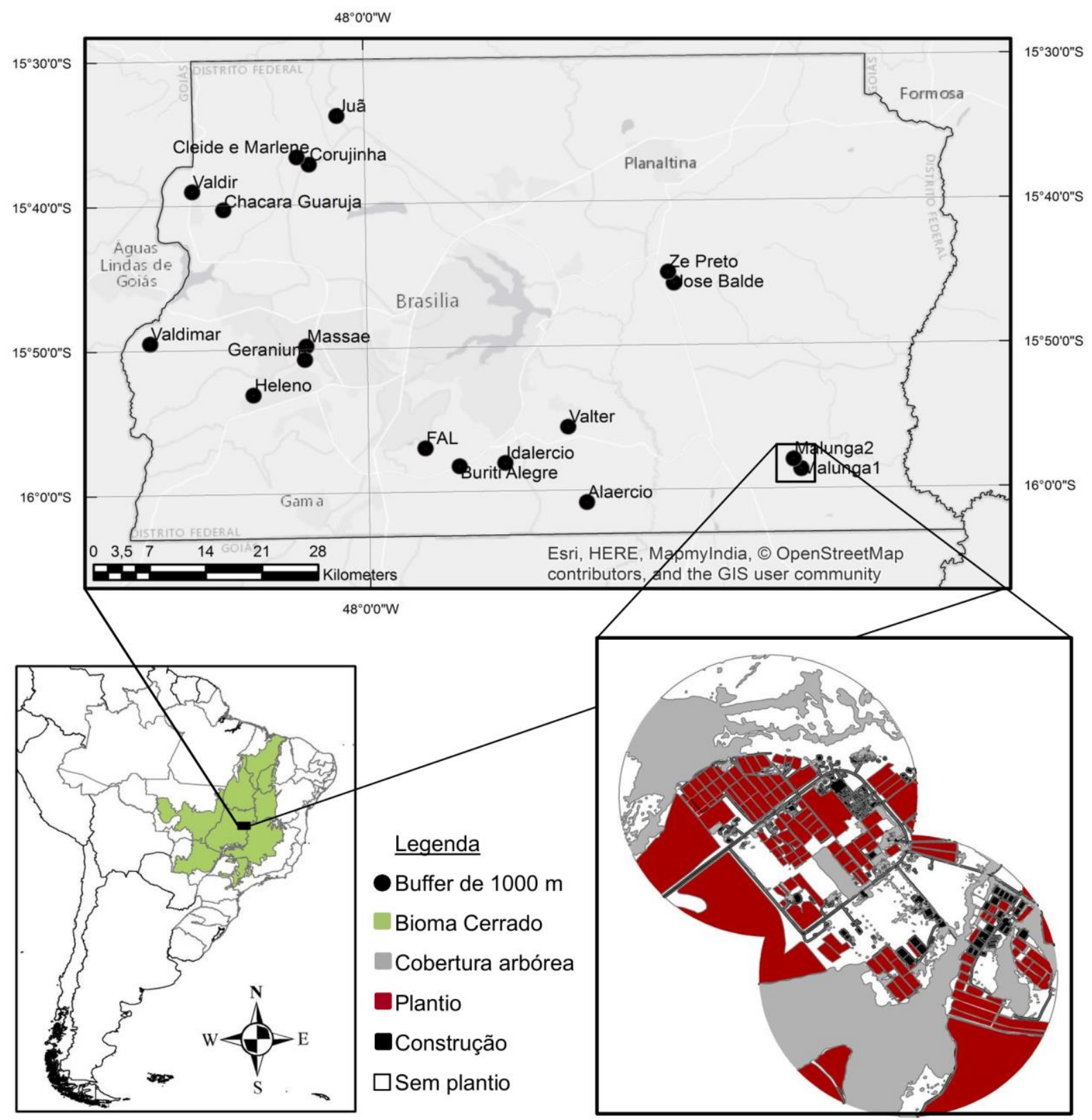

Figura 3.1. Mapa das 18 localidades de agricultura orgânica amostradas no Distrito Federal no ano de 2015 e dois exemplos de buffers categorizados em cobertura arbórea, plantio e construção. 


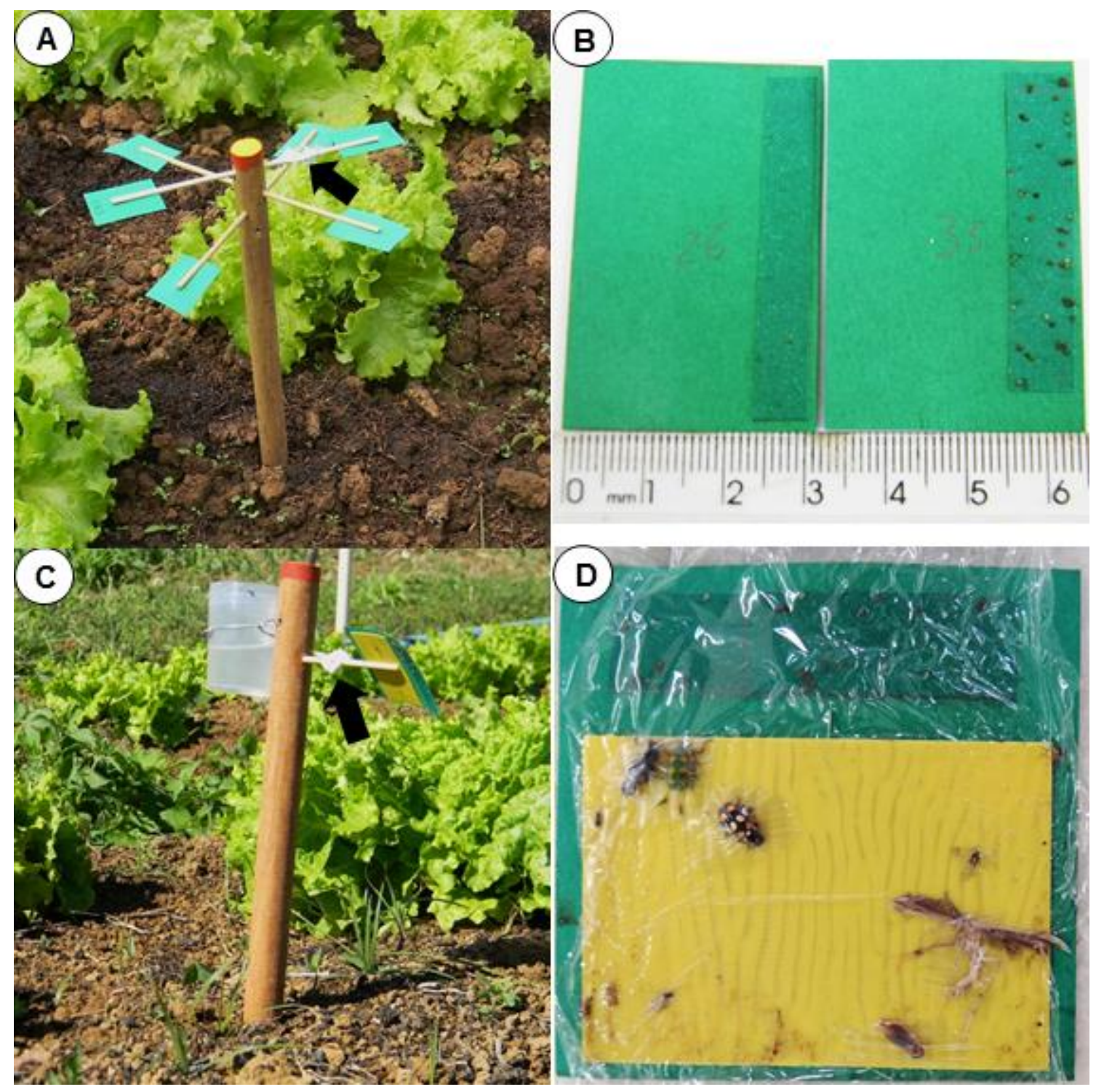

Figura 3.2. Imagens da metodologia empregada nas 18 localidades de produção de hortaliças orgânicas do Distrito Federal no ano de 2015. (A) Fotografia de uma das 720 estacas de predação em campo, onde eram disponibilizadas duas cartelas com ovos de A. gemmatalis. (B) Fotografia das cartelas de ovos após 24 horas em campo, com o número de ovos iniciais escritos a lápis, sendo que na cartela à esquerda ocorreu a predação de todos os ovos. (C) Fotografia de uma das 320 estacas de amostragem, contendo um coletor universal e uma cartela com armadilha amarela adesiva. (D) Fotografia de uma das cartelas de amostragem que ficaram em campo, com uma tira contendo ovos como atrativo na parte superior e coberto por plástico transparente para armazenagem. Setas indicam os locais em (A) e (C) que contêm graxa branca impedindo a passagem de formigas. 
Tabela 3.1. Localização e data de coleta das propriedades amostradas no Distrito Federal no ano de 2015.

\begin{tabular}{|c|c|c|c|}
\hline Localidade & Latitude & Longitude & Data de coleta \\
\hline Juã & $15^{\circ} 33^{\prime} 53.99 " \mathrm{~S}$ & $48^{\circ} 1^{\prime} 53.87^{\prime \prime O}$ & $11-06-2015$ \\
\hline Corujinha & $15^{\circ} 37^{\prime} 14.28^{\prime \prime S}$ & $48^{\circ} 3^{\prime} 52.44^{\prime \prime}$ & $06-08-2015$ \\
\hline Cleide e Marlene & $15^{\circ} 36^{\prime} 43.64^{\prime \prime S}$ & $48^{\circ} 4^{\prime} 42.64^{\prime \prime} \mathrm{O}$ & $11-06-2015$ \\
\hline Chácara Guaruja & $15^{\circ} 40^{\prime} 19.19 " \mathrm{~S}$ & $48^{\circ} 9^{\prime} 52.90 " \mathrm{O}$ & 06-08-2015 \\
\hline Valdir & 15³9'2.36"S & $48^{\circ} 12^{\prime} 2.68^{\prime \prime O}$ & 29-06-2015 \\
\hline Valdimar & $15^{\circ} 49^{\prime} 31.68^{\prime \prime S}$ & $48^{\circ} 15^{\prime} 7.85^{\prime \prime O}$ & 29-06-2015 \\
\hline Massae & $15^{\circ} 49^{\prime} 49.08^{\prime \prime S}$ & $48^{\circ} 4^{\prime} 13.74 " \mathrm{O}$ & $18-06-2015$ \\
\hline Geranium & $15^{\circ} 50^{\prime} 44.80^{\prime \prime S}$ & $48^{\circ} 4^{\prime} 20.94 " \mathrm{O}$ & $18-06-2015$ \\
\hline Heleno & $15^{\circ} 53^{\prime} 9.91^{\prime S}$ & $48^{\circ} 7^{\prime} 57.98^{\prime \prime O}$ & $17-08-2015$ \\
\hline FAL (Faz. Água Limpa) & $15^{\circ} 56^{\prime} 59.04^{\prime \prime} \mathrm{S}$ & $47^{\circ} 56^{\prime} 0.81^{\prime \prime} \mathrm{O}$ & $19-08-2015$ \\
\hline Buriti Alegre & $15^{\circ} 58^{\prime} 15.59^{\prime \prime S}$ & $47^{\circ} 53^{\prime} 38.28 " \mathrm{O}$ & $22-06-2015$ \\
\hline Idalercio & $15^{\circ} 58^{\prime} 4.08^{\prime \prime S}$ & $47^{\circ} 50 ' 27.10^{\prime \prime O}$ & $22-06-2015$ \\
\hline Valter & $15^{\circ} 55^{\prime} 36.51^{\prime \prime S}$ & $47^{\circ} 46^{\prime} 1.40^{\prime \prime} \mathrm{O}$ & 25-06-2015 \\
\hline Alaercio & $16^{\circ} 0^{\prime} 50.76^{\prime \prime S}$ & $47^{\circ} 44^{\prime} 47.17^{\prime \prime} \mathrm{O}$ & $25-06-2015$ \\
\hline Zé Preto & $15^{\circ} 44^{\prime} 57.67 " \mathrm{~S}$ & $47^{\circ} 38^{\prime} 54.86 " \mathrm{O}$ & $15-06-2015$ \\
\hline José Balde & $15^{\circ} 45^{\prime} 44.00^{\prime \prime S}$ & $47^{\circ} 38^{\prime} 30.58 " \mathrm{O}$ & $15-06-2015$ \\
\hline Malunga 1 & $15^{\circ} 58^{\prime} 40.96 " \mathrm{~S}$ & $47^{\circ} 29^{\prime} 46.19 " \mathrm{O}$ & 03-08-2015 \\
\hline Malunga 2 & $15^{\circ} 57^{\prime} 59.41^{\prime \prime S}$ & $47^{\circ} 30^{\prime} 17.73 " \mathrm{O}$ & 03-08-2015 \\
\hline
\end{tabular}

Tabela 3.2. Porcentagem mínima e máxima da ocorrência de diferentes categorias da paisagem no entorno das 18 localidades de produção de hortaliças orgânicas amostradas no Distrito Federal, no ano de 2015.

\begin{tabular}{lcccccccc}
\hline & \multicolumn{2}{c}{ Buffer 1000m } & \multicolumn{2}{c}{ Buffer 500m } & \multicolumn{2}{c}{ Buffer 250m } & \multicolumn{2}{c}{ Buffer 125m } \\
\hline & Mínimo & Máximo & Mínimo & Máximo & Mínimo & Máximo & Mínimo & Máximo \\
\hline Construção & $2,8 \%$ & $37,8 \%$ & $2,2 \%$ & $43,9 \%$ & $2,8 \%$ & $40,4 \%$ & $1,8 \%$ & $21,7 \%$ \\
Cobertura arbórea & $2,7 \%$ & $38,7 \%$ & $3,4 \%$ & $46,9 \%$ & $3,2 \%$ & $35,9 \%$ & $2,8 \%$ & $41,4 \%$ \\
Plantio & $0,2 \%$ & $31,2 \%$ & $0,5 \%$ & $45,3 \%$ & $2,0 \%$ & $57,0 \%$ & $7,9 \%$ & $79,7 \%$ \\
Sem plantio & $33,1 \%$ & $84,5 \%$ & $24,3 \%$ & $86,7 \%$ & $18,3 \%$ & $81,7 \%$ & $9 \%$ & $78,3 \%$ \\
\hline
\end{tabular}




\section{Resultados}

Desconsiderando as formigas, foram coletados 3.631 espécimes de artrópodes (Figura 3.3), entre estes, 406 predadores (Figura 3.4). Os predadores mais comuns foram Coleoptera (178 indivíduos), destacando-se a família Staphylinidae (105) e Coccinellidae (71). A ordem Diptera foi a segunda mais comum entre os predadores, com a família Dolichopodidae (128), porém estes são predadores preferenciais de animais em voo e de pequeno porte (HarterreitenSouza, comunicação oral), não sendo observadas em campo a predação de ovos de $A$. gemmatalis, por isso não foram incorporados às análises dos predadores. Os outros predadores encontrados foram Hemiptera-Heteroptera (35), Araneae (27), HymenopteraVespoidea (25), Neuroptera (6), Psocoptera (2), Pseudoscorpionida (1), Coleoptera-Melyridae (1) e Coleoptera-Carabidae (1).

A utilização de graxa branca para evitar a passagem de formigas demonstrou ser eficiente, apesar de não ser infalível (Figura 3.4). Ao todo, foram capturados 1.831 indivíduos de formigas, em 244 ocorrências (Tabela 3.3), e distribuídos em 35 espécies com potencial para atuar como predadoras dos ovos. Além destas, foi realizado um registro de Atta laevigata (Smith, 1858), uma espécie de formiga que atua funcionalmente como herbívora. As espécies de formigas mais frequentes foram Linepithema micans (Forel, 1908), Dorymyrmex cf. brunneus (Forel, 1908) e Linepithema cf. cerradense (Wild, 2007), todas da subfamília Dolichoderinae. Porém, a espécie com maior número de indivíduos foi Pheidole gertrudae (Forel, 1886), da subfamília Myrmicinae. De modo geral, as dez espécies mais comuns de formigas representaram mais de $80 \%$ da ocorrência de formigas.

O número de ovos predados entre controle e tratamento (Figura 3.5) demostra que formigas são seus principais predadores (teste-t pareado, $\mathrm{t}=12.445, \mathrm{df}=717, \mathrm{p}<0,0001$ ). Em média a porcentagem estimada de ovos predados é de aproximadamente $39,8 \%$ por dia, 
dos quais $26,8 \%$ são por formigas e $13 \%$ por outros predadores. Há, porém, muita variação entre as propriedades, tanto na predação total, variando de $9,4 \%$ até $63,2 \%$ dos ovos, como na predação só por formigas (de 5,3\% até $52,4 \%$ ) ou só por outros predadores $(4,2 \%$ até $21 \%$ ).

Análises de modelos lineares mostram que o número total de ovos predados e o de ovos predados por formigas em cada localidade orgânica não sofre influência da paisagem (Tabela 3.4). No entanto, área plantada no raio de 500 metros influencia positivamente os ovos predados no controle, além da influência de interações com o resto da paisagem.

Em contrapartida, as regressões entre o número de ovos predados e o número de predadores foram todas significativas (Figura 3.6). O número de ovos predados no tratamento é positivo e significativamente relacionado com o número total de predadores $\left(\mathrm{N}^{\mathrm{o}}\right.$ de ovos predados $=129,4+4,878 \times \mathrm{N}^{\circ}$ de predadores, $\left.\mathrm{R}^{2}=0,41, \mathrm{p}=0,004\right)$. Assim como o controle $\left(\mathrm{N}^{\mathrm{o}}\right.$ de ovos predados $=49,8+2,6 \times \mathrm{N}^{\mathrm{o}}$ de predadores não formigas, $\left.\mathrm{R}^{2}=0,27, \mathrm{p}=0,025\right)$ e o tratamento menos o controle $\left(\mathrm{N}^{\mathrm{o}}\right.$ de ovos predados $=110,5+5,185 \times \mathrm{N}^{\mathrm{o}}$ de ocorrência de formigas, $\left.\mathrm{R}^{2}=0,30, \mathrm{p}=0,017\right)$. Por fim, também se encontrou uma correlação para formigas entre sua ocorrência e a riqueza de espécies $(t=7,5254, \mathrm{R}=0,88, \mathrm{p}<0,001)$. 


\section{Grupos funcionais capturados}

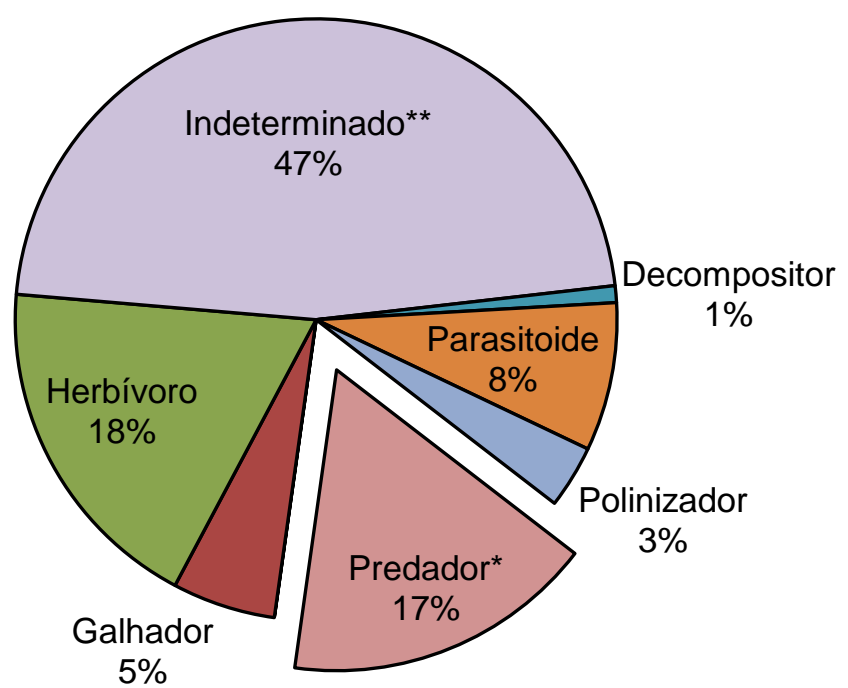

Figura 3.3. Proporção dos 3.875 indivíduos capturados em função do grupo funcional ao qual pertencem. As coletas foram realizadas em 18 localidades de produção de hortaliças orgânicas do Distrito Federal no ano de 2015, utilizando 360 coletores universais e 360 cartelas de armadilha adesiva amarela.

*Para o grupo predador as formigas foram contabilizadas em número de ocorrência (244) ao invés de número de indivíduos (1.831).

**Para o grupo dos indeterminados, dos 1.814 registros, 1.558 foram da ordem Diptera, ou seja, $86 \%$. 


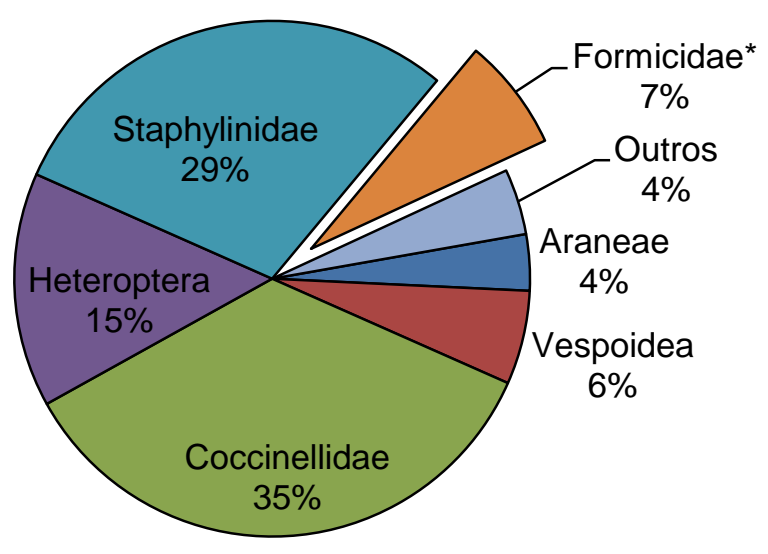

\section{Predadores amostrados no coletor universal}

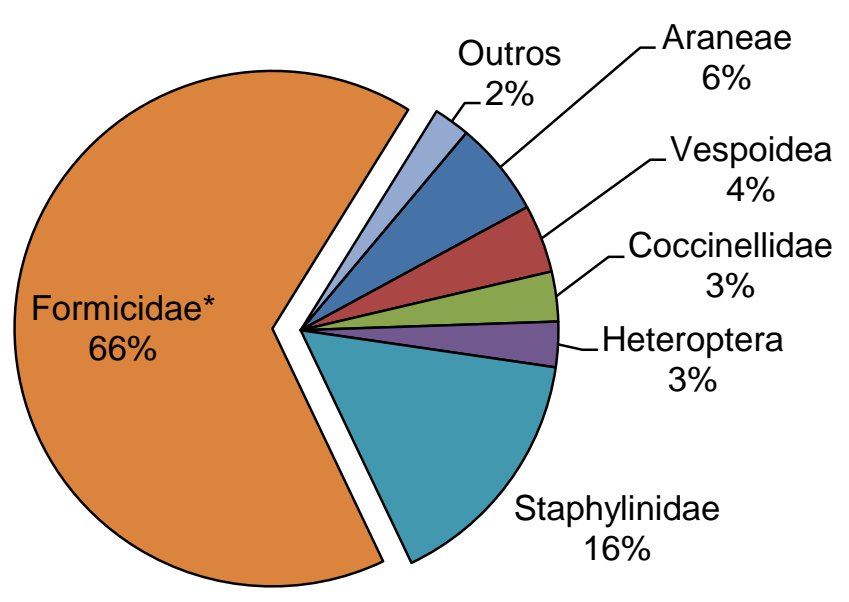

Figura 3.4. Proporção do táxon de predadores capturados na armadilha adesiva amarela (170 registros) e no coletor universal (352 registros). As coletas foram realizadas em 18 localidades de produção de hortaliças orgânicas do Distrito Federal no ano de 2015, utilizando 360 coletores universais e 360 cartelas de armadilha adesiva amarela. Nessa figura, a família Dolichopodidae, com 128 indivíduos, foi suprimida.

*Para a Família Formicidae as formigas foram contabilizadas em número de ocorrência (244) ao invés de número de indivíduos (1.831). 


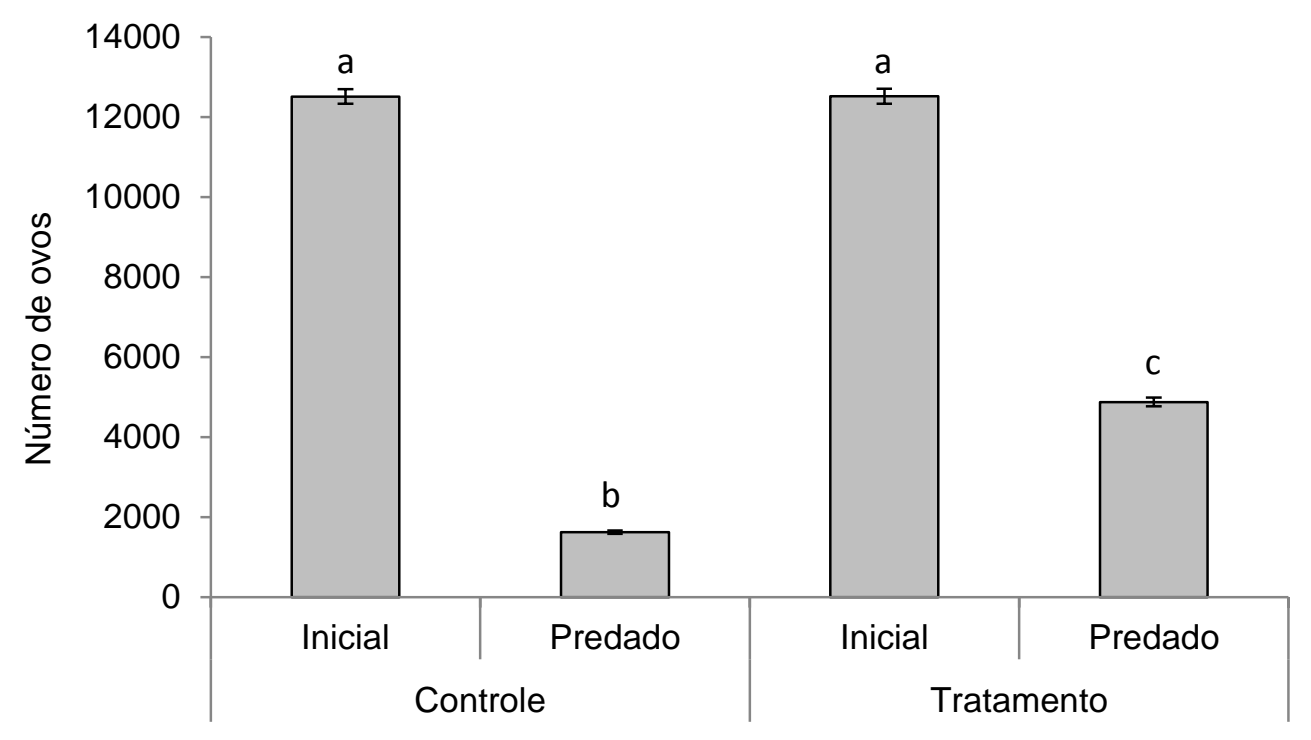

Figura 3.5. Número de ovos de A. gemmatalis disponibilizados e predados nas cartelas de controle (sem acesso às formigas) e tratamento (com acesso às formigas). $\mathrm{O}$ experimento foi realizado em 18 localidades, dentro do Distrito Federal no ano de 2015. Barras representam desvio padrão e letras diferentes indicam diferenças significativas $(\mathrm{p}<0,05)$. 

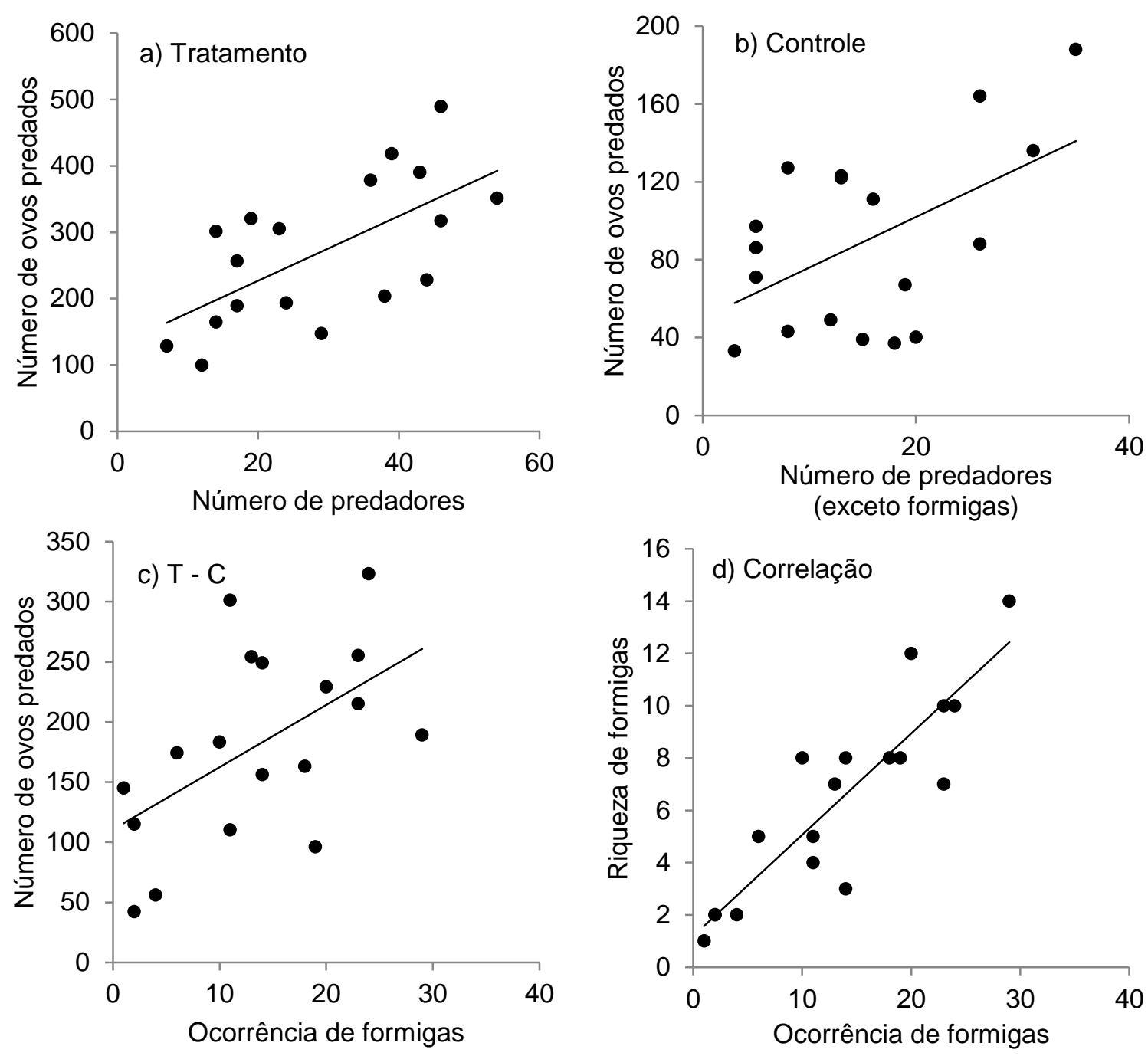

Figura 3.6. Relações lineares entre abundância, predação ou riqueza, de modo que: (a) ovos predados nas cartelas tratamento em relação a todos os predadores; (b) ovos predados nas cartelas controle em relação aos predadores exceto formigas; (c) ovos predados no tratamento menos o controle (predação atribuída às formigas) em relação à ocorrência de formigas; e (d) correlação entre a riqueza de formigas e sua ocorrência. Para todas as regressões e a correlação, os resultados foram significativos $(\mathrm{p}<0,05)$. Esses dados são baseados no experimento realizado em 18 localidades, dentro do Distrito Federal no ano de 2015. 
Tabela 3.3. Lista de espécies de formigas potencialmente predadoras de ovos de A. gemmatalis capturadas nas 360 estacas de amostragem. As coletas foram realizadas em 18 localidades de produção de hortaliças orgânicas do Distrito Federal no ano de 2015.

\begin{tabular}{|c|c|c|c|c|}
\hline Espécies & $\begin{array}{c}\text { № de } \\
\text { localidades } \\
\text { com ocorrência }\end{array}$ & $\begin{array}{l}\text { № de indivíduos } \\
\text { capturados }\end{array}$ & Ocorrência & $\begin{array}{l}\text { Porcentagem } \\
\text { acumulativa de } \\
\text { ocorrência }\end{array}$ \\
\hline Linepithema micans & 11 & 371 & 44 & $18 \%$ \\
\hline Dorymyrmex cf. brunneus & 10 & 245 & 33 & $32 \%$ \\
\hline Linepithema cf. cerradense & 7 & 154 & 22 & $41 \%$ \\
\hline Camponotus sp.12 & 9 & 26 & 22 & $50 \%$ \\
\hline Camponotus sp.16 & 8 & 57 & 20 & $58 \%$ \\
\hline Pheidole gertrudae & 7 & 493 & 14 & $64 \%$ \\
\hline Dorymyrmex cf. jheringi & 5 & 82 & 14 & $69 \%$ \\
\hline Pheidole sp.01 & 7 & 104 & 12 & $74 \%$ \\
\hline Pheidole sp.24 & 5 & 102 & 8 & $77 \%$ \\
\hline Solenopsis saevissima & 4 & 44 & 8 & $81 \%$ \\
\hline Camponotus gr. senex & 6 & 13 & 6 & $83 \%$ \\
\hline Brachymyrmex sp03 & 4 & 47 & 5 & $85 \%$ \\
\hline Pheidole sp.23 & 3 & 14 & 4 & $87 \%$ \\
\hline Camponotus gr. blandus & 3 & 7 & 4 & $89 \%$ \\
\hline Pheidole sp.13 & 1 & 9 & 2 & $89 \%$ \\
\hline Nylanderia sp.03 & 1 & 8 & 2 & $90 \%$ \\
\hline Pheidole sp.20 & 2 & 7 & 2 & $91 \%$ \\
\hline Pheidole sp.22 & 2 & 7 & 2 & $92 \%$ \\
\hline Brachymyrmex sp.01 & 2 & 6 & 2 & $93 \%$ \\
\hline Labidus praedator & 2 & 6 & 2 & $93 \%$ \\
\hline Brachymyrmex sp.02 & 2 & 2 & 2 & $94 \%$ \\
\hline Pseudomyrmex termitarius & 1 & 6 & 1 & $95 \%$ \\
\hline Camponotus sp.17 & 1 & 4 & 1 & $95 \%$ \\
\hline Crematogaster sp.10 & 1 & 3 & 1 & $95 \%$ \\
\hline Pheidole sp.03 & 1 & 3 & 1 & $96 \%$ \\
\hline Camponotus arboreus & 1 & 2 & 1 & $96 \%$ \\
\hline Camponotus atriceps & 1 & 1 & 1 & $97 \%$ \\
\hline Camponotus sp.18 & 1 & 1 & 1 & $97 \%$ \\
\hline Camponotus sp.46 & 1 & 1 & 1 & $98 \%$ \\
\hline Cardiocondyla sp.01 & 1 & 1 & 1 & $98 \%$ \\
\hline Pheidole sp.02 & 1 & 1 & 1 & $98 \%$ \\
\hline Pheidole sp.04 & 1 & 1 & 1 & $99 \%$ \\
\hline Pheidole sp.37 & 1 & 1 & 1 & $99 \%$ \\
\hline Pseudomyrmex rufiventris & 1 & 1 & 1 & $99 \%$ \\
\hline Solenopsis sp.02 & 1 & 1 & 1 & $100 \%$ \\
\hline
\end{tabular}


Tabela 3.4. Modelo linear que explica a influência da paisagem sobre as taxas de predação de ovos de $A$. gemmatalis. O experimento foi realizado em 18 localidades de produção de hortaliças orgânicas do Distrito Federal no ano de 2015.

\begin{tabular}{|c|c|c|c|c|c|}
\hline Fator e escala espacial & Modelo & Estimativas & $\begin{array}{c}\mathrm{R}^{2} \\
\text { Ajustado }\end{array}$ & AIC & Valor de $p$ \\
\hline \multicolumn{6}{|l|}{ a) Ovos predados (total) } \\
\hline Buffer $1000 \mathrm{~m}$ & (nenhum) & - & - & - & $<0,05$ \\
\hline Buffer 500m & (nenhum) & - & - & - & $<0,05$ \\
\hline Buffer 250m & (nenhum) & - & - & - & $<0,05$ \\
\hline Buffer $125 \mathrm{~m}$ & (nenhum) & - & - & - & $<0,05$ \\
\hline \multicolumn{6}{|l|}{ b) Ovos predados por } \\
\hline \multicolumn{6}{|l|}{ formigas } \\
\hline Buffer 1000m & (nenhum) & - & - & - & $<0,05$ \\
\hline Buffer 500m & (nenhum) & - & - & - & $<0,05$ \\
\hline Buffer 250m & (nenhum) & - & - & - & $<0,05$ \\
\hline Buffer $125 \mathrm{~m}$ & (nenhum) & - & - & - & $<0,05$ \\
\hline \multicolumn{6}{|l|}{ c) Ovos predados no } \\
\hline \multicolumn{6}{|l|}{ Controle } \\
\hline Buffer $1000 \mathrm{~m}$ & (nenhum) & - & - & - & $<0,05$ \\
\hline \multirow[t]{5}{*}{ Buffer 500m } & Plantio & $2.306 \mathrm{e}-03$ & 0.3003 & 189,7 & 0,0103 \\
\hline & $\begin{array}{l}\text { Construção x Cobertura } \\
\text { arbórea }\end{array}$ & $2.533 \mathrm{e}-09$ & & & 0,0361 \\
\hline & Plantio x Construção & $-3.550 e-08$ & & & 0,0142 \\
\hline & $\begin{array}{l}\text { Cobertura arbórea x Sem } \\
\text { plantio }\end{array}$ & $-1.577 \mathrm{e}-09$ & & & 0,0065 \\
\hline & Plantio x Sem plantio & $-2.402 \mathrm{e}-09$ & & & $\mathbf{0 , 0 3 3 7}$ \\
\hline Buffer $250 \mathrm{~m}$ & (nenhum) & - & - & - & $<0,05$ \\
\hline Buffer $125 \mathrm{~m}$ & (nenhum) & - & - & - & $<0,05$ \\
\hline
\end{tabular}




\section{Discussão}

Conseguiu-se, neste estudo, isolar os efeitos de predadores alados em relação aos não alados, atráves do uso de graxa branca, assim como também realizado por Rabelo \& Francini (2014) (Figuras 3.4 e 3.5). Apesar deste isolamento não ser completo - visto que 12 formigas também foram encontradas nas armadilhas adesivas amarelas -, podemos considera-lo eficiente. Evidentemente formigas não foram os únicos predadores isolados durante o experimento, além destas, em tese também podem ter sido isoladas aranhas, ninfas e larvas predadoras, as quais também podem ter contribuído para as taxas de predação no tratamento. No entanto, a ocorrência destes predadores foi similar à ocorrida no controle, e desprezível se comparada à de formigas.

Sendo assim, os dados sugerem fortemente que as formigas são os principais predadores de ovoposições de A. gemmatalis em hortaliças ou arbustos nas áreas de agricultura orgânica (Figura 3.5). O mesmo também foi observado em outros estudos em diferentes países: na Colômbia, Armbrecht \& Gallego (2007) mediram uma taxa de predação por formigas de 30,5\% sobre a broca-do-café (Hypothenemus hampei) em cinco dias; nos EUA, Karban et al. (2013) encontraram de $20 \%$ a $40 \%$ de predação sobre a lagarta Platyprepia virginalis em oito dias; e López \& Potter (2000) encontraram uma predação de 65,5\% a 71,8\% sobre ovos da lagarta (Agrotis ipsilon), durante 22 horas em campos de golfe. Offberg (2015) faz uma revisão, com estudos da Oceania e sudeste Asiático, demonstrando que, de 17 publicações diferentes, formigas do gênero Oecophilla só não reduziram o tamanho populacional de pragas em um dos estudos.

Dentre as espécies de formiga amostradas, fica evidente que poucas são responsáveis pela maior parte da predação (Tabela 3.3). Surpreendentemente as três espécies mais frequentes capturadas nas estacas foram da subfamília Dolichoderinae, pertencentes aos 
gêneros Linepthema e Dorymyrmex, reconhecidamente um grupo que apresenta tolerância térmica a altas temperaturas e preferência por locais abertos (Farji-Brener et al. 2002; Cuezzo 2011), comuns nos agrossistemas do Cerrado. Geralmente, os estudos têm apontado os gêneros Pheidole e Solenopsis como os principais predadores nas áreas agrícolas neotropicais (Risch \& Carroll 1982: Armbrecht et al. 2007), principalmente por terem características de predadoras generalistas, grande capacidade de recrutamento e subjugarem presas muitas vezes maiores que elas próprias. Mas o que se encontrou é que, apesar destes gêneros dominarem de fato a superfície do solo (Frizzo, dados do Capítulo I e II), a habilidade das espécies dos gêneros Dorymyrmex e Linepithema, assim como secundariamente o gênero Camponotus, de subir nas plantas arbustivas, confere a esses o papel de principais predadores de ovos de $A$. gemmatalis sobre as hortaliças. Porém, as formigas da subfamília Myrmicinae, que somam $24 \%$ das ocorrências e são representadas principalmente pelo gênero Pheidole, tiveram as maiores médias de indivíduos recrutados por ocorrência (média de 13,4 indivíduos) em comparação à subfamília Dolichoderinae $(7,5)$ e Formicinae $(2,6)$.

Complementando o papel desempenhado pelas formigas, uma metanálise com estudos em agrossistemas encontrou que predadores generalistas controlam a abundância de herbívoros em $79 \%$ das publicações analisadas, e em $65 \%$ dos estudos reduzem o dano na planta ou aumentam o rendimento da produção (Symondson et al. 2002). De fato, a existência de cultivos orgânicos comerciais só é possível devido à presença dos predadores que controlam a ocorrência de pragas (e.g. Birkhofer et al. 2016). Mas além das formigas, outros predadores das ordens Coleoptera, Dermaptera, Neuroptera e Diptera também contribuem substancialmente para esse serviço ecológico (Harterreiten-Souza et al. 2014; Togni et al. 2016).

Quando se analisa o controle de pragas em sistemas agrícolas, é importante ressaltar que a identidade da praga afeta a capacidade desta de ser controlada por um determinado 
táxon de predador. Por exemplo, formigas evidentemente são ótimos predadores de ovos, como visto aqui, porém pragas aladas, como adultos da mosca branca (Bemisia tabaci, Gennadius 1889), em tese, dificilmente seriam predadas por formigas, devido ao seu tamanho reduzido e à capacidade de voo, sendo este alvo preferencial de alguns predadores das ordens Hemiptera, Neuroptera e Coleoptera (Naranjo 2001). Outro exemplo disso é presença de afídeos, um fitófago que pode se associar mutualisticamente às formigas sendo protegido por estas (Styrsk \& Eubanks 2007). Assim, joaninhas (Coccinellidae) atuariam como predadores complementares para afídeos e redundantes para ovos (Togni et al. 2016).

Para melhor demonstrar o quanto a predação pode ser benéfica aos produtores, podemos simular os cálculos de herbívoria foliar. Segundo Bueno et al. (2011), em toda a faze larval da A. gemmatalis, ela consome em média $89 \mathrm{~cm}^{2}$ de área folhar de soja (variando entre tipos de cultivar). Supondo que todos os ovos predados deste experimento gerassem larvas, que tivessem consumido $89 \mathrm{~cm}^{2} /$ indivíduo de área foliar, em média, cada localidade sofreria um dano de $2,4 \mathrm{~m}^{2} /$ dia de perda de área foliar. Sendo, um terço desta perda foliar evitado por predadores não alados e o restante pela predação exercida por formigas.

Muitos estudos têm sugerido que a paisagem tem importância, sendo ela provedora de biodiversidade e podendo incrementar a presença de predadores de múltiplos táxons e consequentemente aumentar o potencial do serviço ecológico de controle biológico (Rusch et al. 2013). No entanto, não foi isso que se encontrou neste estudo, já que se observa que a paisagem não tem influência para o total de ovos predados e aqueles predados apenas por formigas (Tabela 3.5). Assim como visto em outros estudos, a influência e importância relativa de cada fator da paisagem variam de acordo com o táxon estudado (Winqvist et al. 2011; Lemessa et al. 2015). Segundo Bikhofer et al. (2016), em sistemas orgânicos é possível manter o controle biológico de pragas, independente da paisagem, através do manejo delas. 
Mas esse manejo depende do tipo de praga, do predador e da interação que existe entre esses dois.

Ao contrário das nossas expectativas, a cobertura arbórea na paisagem, que está ligada principalmente a ocorrência de formações florestais, não teve efeito isolado do resto da paisagem sobre a predação de ovos exercida por nenhum predador. Para formigas, isso reflete a especialização de habitats, assim como visto no Capítulo I e por Pacheco \& Vasconcelos (2012), pois a comunidade de formigas das áreas florestais é um grupo de espécies diferente das que ocorrem nos agrossistemas. No entanto, outro estudo no Cerrado demonstrou que a presença de árvores espalhadas nos sistemas agrícolas aumenta a riqueza local de espécies de formigas (Frizzo \& Vasconcelos 2013), o que está correlacionado com a ocorrência de formigas (Figura 3.6) e possivelmente pode gerar um incremento nas taxas de predação, mas ainda sem comprovação científica.

Para os predadores, excluindo-se formigas, a cobertura arbórea tem efeito sobre as taxas de predação interagindo com outras categorias da paisagem (Tabela 3.4). Assim como visto por Harterreiten-Souza et al. (2014), nessa região, a formação florestal aumenta a diversidade tanto de herbívoros como de predadores nos cultivos do entorno, servindo de fonte de inimigos naturais. A presença de formações florestais na paisagem está relacionada ao aumento de recursos alternativos e à disponibilidade de local de refúgio para períodos de baixa disponibilidade de recurso, tanto para predadores como para pragas (revisado por Landis et al. 2000; Langellotto \& Denno 2004).

Já a presença de plantio na paisagem, significativamente aumenta as taxas de predação por predadores alados (e.g. Liere et al. 2015), provavelmente, porque está ligada a hipótese de concentração de recurso (Root 1973) e por manter um conjunto de espécies regional já adaptado aos agrossistemas. Porém é importante resaltar que proporções muito altas de plantio convencional na paisagem - acima dos 31,2\% da paisagem, como analisado aqui -, 
têm demonstrado efeito negativo sobre a biodiversidade e seus serviços (Langellotto \& Denno 2004; Tscharntke et al. 2005). Além disso, como visto na Tabela 3.4, existem várias interações entre as categorias da paisagem, indicando que o resto da paisagem também influencia a predação de ovos por predadores alados, mesmo que essa influência para as interações sejam padrões complexos e com um modelo que se ajuste relativamente mal aos $\operatorname{dados}\left(\mathrm{r}^{2}\right.$ ajustado=0,30).

Entretanto, para explicar as taxas de predação foram encontradas relações significativas com a abundância de todos os predadores, além dos predadores alados e formigas (Figura 3.6). Isso provavelmente está ligado à hipótese de mais indivíduos (Srivastava \& Lawton 1998), segundo a qual, quanto mais recurso, maior é quantidade de consumidores. Neste caso, uma quantidade maior de recurso nas propriedades implica em um número maior de predadores e, consequentemente, em maiores taxas de predação. Isso sugere um sucesso na capacidade das propriedades com altas taxas de predação em conseguir aumentar o número de predadores, porém não se foi capazes de determinar o que causa essa maior abundância. Na literatura, já é sabido que a disponibilidade de recursos florais é um alimento alternativo para predadores como joaninhas (Lundgren 2009). Além disso, as fazendas podem ser manejadas para criar uma "infraestrutura ecológica" adequada para aumentar o controle biológico (revisado por Landis et al. 2000). Também se observou que, aparentemente, o uso de matéria orgânica (folhas, serragem, casca de arroz entre outros) para adubação pode estar ligado a um aumento na disponibilidade de presas alternativas (detritívoros) para as formigas. Entretanto, isso é baseado em observações de campo, realizadas principalmente na propriedade Juã. Além disso, dados na literatura sugerem que o aumento da complexidade do ambiente com o incremento de serrapilheira teria o efeito inverso ao sugerido aqui, reduzindo a probabilidade de predação (Gibb \& Parr 2010; Karban et al. 2013). 


\section{Conclusão}

As formigas, apesar do desconhecimento por parte dos produtores, é um importante grupo de insetos predadores, capazes de reduzir a população de ovos de uma lagarta praga nas plantas de fazendas orgânicas numa média de 26,8\% ao dia. Destaca-se também que os outros predadores amostrados consistem principalmente de duas famílias da ordem Coleoptera (Coccinellidae e Staphylinidae) que, juntamente com outros táxons de predadores, removeram $13 \%$ dos ovos disponíveis.

A paisagem apresenta um efeito limitado apenas sobre a predação realizada pelos predadores alados, sendo influenciados positivamente por áreas de plantio e por interações entre o resto da paisagem, em um raio de 500 metros. Foi encontrado por fim, uma relação positiva entre a abundância dos predadores e suas respectivas taxas de predação. O que indica que o sucesso da conservação do controle biológico, dentro de áreas orgânicas, está associado a capacidade desses sistemas de conseguir manter uma grande quantidade de predadores. 


\section{Considerações finais}

\section{Padrões encontrados}

A redução da biodiversidade local, regional e global, devido à atividade agrícola, é aparentemente um padrão universal, mas a intensidade dessa redução é dependente da proporção e tipo de uso da terra (e.g. Sala et al. 2000; Rockströn et al. 2009; Newbold et al. 2015). Isso porque tornar sistemas complexos com milhares a milhões de anos de evolução em sistemas simplificados causa a exclusão de espécies (Tscharntke et al. 2005). Assim como confirmado por este estudo, no Cerrado não é diferente, mas tão importante quanto detectar o efeito - redução da biodiversidade - é determinar a magnitude deste efeito, já que ele varia em função do táxon, tipo de uso da terra (Kessler et al. 2009; Bommarco et al. 2014) e da região geográfica (Newbold et al. 2015). Isso se evidencia porque se mostrou que o cultivo de soja convencional é o mais restritivo para a mirmecofauna nativa do Cerrado, contendo apenas $17 \%$ das espécies da região, e mesmo áreas de pastagens e agricultura orgânica sendo menos impactantes comportam aproximadamente metade da fauna nativa.

A diversidade de espécies de formigas no Cerrado é em grande parte dependente de espécies raras, comparativamente, por exemplo, à savana Australiana (Campos et al. 2011). Essas espécies raras são as mais suscetíveis à extinção (Didham et al. 1996; Weiner et al. 2014). E, assim como se mostrou, a riqueza de formigas está correlacionada com: a biomassa de formigas; a ocorrência de formigas; e determinadas funções ou serviços do ecossistema como remoção de biomassa e predação. Portanto, ressalta-se que a perda dessas espécies raras pode ter implicações negativas na biomassa de artrópodes e funções do ecossistema.

As matas comportaram o grupo de espécies de formigas mais singular do estudo. Essas espécies florestais geralmente não ocorrem nas paisagens agrícolas e, por isso, para as formigas do Cerrado, áreas de mata na paisagem não aumentam o controle biológico em áreas 
agrícolas adjacentes. No entanto, destaca-se que para outros táxons matas podem ser fonte de agentes de controle biológico (Harterreiten-Souza et al. 2014).

Detectaram-se também mecanismos de redundância entre formigas e outros predadores (sendo os principais pertencentes à Ordem Coleoptera). Mecanismos de redundância também existem nos cultivos de soja, no qual, na ausência de formigas a remoção de biomassa de banana (recurso que simula apêndices atrativos de semente e frutas) é realizada por outros táxons.

\section{Implicações}

Na prática, porém, a expansão da agricultura sobre áreas de vegetação nativa no Cerrado ainda é uma realidade, com apenas $2,2 \%$ da área sobre proteção legal e com taxas de desmatamento superior às da Amazônia (Klink \& Machado 2005). Por isso é imperativo que as ações conservacionistas passem a incluir os sistemas agrícolas (Tscharntke et al. 2015). Sugere-se também que determinados tipos de uso da terra (como pastagem ou agricultura orgânica) sejam preferencialmente usados no entornos de áreas de proteção ambiental ou de relevante biodiversidade como forma de amortização dos efeitos de sistemas intensificados, como a produção de soja.

Os motivos pelos quais, nos cultivos de soja, o número de espécies e biomassa de formigas é menor comparativamente aos outros sistemas ainda não foi conclusivamente estudado. Mas se aponta que arar o solo (Pereira et al. 2010; Köhl et al. 2014) e uso de agrotóxicos (revisado por Aktar et al. 2009) afetam vários organismos. Além destes, a redução de local para nidificação das formigas e efeitos indiretos, como competição interespecífica, também são sugeridos (Philpott \& Foster 2005; Armbrecht et al. 2006; Frizzo \& Vasconcelos, 2013; Pacheco et al. 2013). 
Comparações entre os cultivos orgânicos e de soja são um indicativo de que o fator mais importante para redução da biodiversidade na soja talvez seja o uso de agrotóxico. Entretanto isso não é conclusivo, visto que as propriedades de produção orgânica são produtivas durante todo ano e entremeadas por plantas perenes, o que pode influenciar positivamente na capacidade das formigas de persistirem nestes ambientes.

Todavia, é um fato, segundo dados da ABRASCO (2015), que nos últimos anos há um aumento desproporcional no uso de inseticidas, que de 2000 a 2012 teve um crescimento acumulado de 162,3\%, sendo hoje, o Brasil o maior consumidor de agrotóxicos do mundo (MMA 2016). Em uma revisão, Popp et al. (2013) indicam algumas formas para se reduzir os possíveis impactos de sistemas altamente manejados como a soja. A primeira, seria aumentar o uso de cultivos geneticamente modificados, que são resistentes a determinados tipos de praga, e, consequentemente, demandam um menor consumo de agrotóxicos. A segunda é, assim como ocorre na Noruega, os agrotóxicos poderiam ser taxados de acordo com sua toxicidade, elevando o custo daqueles que são potencialmente mais perigosos. Por último, pode-se utilizar o MIP (manejo integrado de pragas), uma técnica com mais de três décadas no Brasil. Essa técnica consiste no combate às pragas utilizando várias metodologias, e recorrendo aos agrotóxicos somente quando a população de pragas atinge um determinado tamanho (chamado de nível de controle). Assim como discutido no XXVI Congresso de Entomologia, os agricultores brasileiros abandonaram o uso do MIP e têm realizado pulverizações preventivas, com a mistura de diferentes produtos e em quantidades desnecessárias, aumentando inclusive os casos de resistência de pragas.

Em relação às pastagens, elas apresentam desvantagem em comparação com as áreas de agricultura orgânica. Primeiro que para se produzir $1 \mathrm{~kg}$ de carne é necessário utilizar 303 $\mathrm{m}^{2}$ de pastagem, o que equivale a 83 vezes mais área do que para produzir $1 \mathrm{~kg}$ de cereal, ou 382 vezes mais área do que para produzir $1 \mathrm{~kg}$ de raiz ou tubérculo, ou, ainda, 545 vezes mais 
área do que para produzir $1 \mathrm{~kg}$ de hortaliça (Wackernagel et al. 1999). Outro fator de preocupação é a utilização do capim exótico Melinis minutiflora como forrageira, que é considerado mais danoso ao meio ambiente que o Urochloa (Syn. Brachiaria) decumbens, principalmente pela dominância competitiva em relação às espécies nativas e pelos efeitos indiretos em caso de queimada (Pivello et al. 1999; Hoffmann et al. 2004).

Em contrapartida, a agricultura orgânica contempla muitos pequenos produtores, o que traz benefícios sociais, ambientais e aumenta a segurança alimentar (Tscharntke et al. 2012). No entanto, mesmo áreas de agricultura orgânica têm sido submetidas ao que Hall \& Mogyorody (2001) chamam de "convencionalização", que é um processo de aumento da produção, respeitando as normas dos produtos orgânicos, mas não os princípios (Blanc 2009). Isso demonstra que a evolução do agronegócio e a expansão de suas atividades são a principal ameaça à mirmecofauna do Cerrado, o que provavelmente ocorre com os outros táxons (Silva et al. 2006).

Por fim, em uma revisão, De Fries et al. (2004) aponta que há um balanço entre as necessidades humanas imediatas e a manutenção das funções do ecossistema, sendo que esse equilíbrio é afetado pelos valores da sociedade. Ou seja, o uso exacerbado dos recursos naturais pode causar prejuízos à sociedade, assim como trazer benefícios imediatos (como conforto ou lucro financeiro). A medida desse equilíbrio é dada pela informação recebida pela sociedade, importância que ela dá a estas informações e como esta é interpretada e influencia suas decisões. 


\section{Referências Bibliográficas}

ABRASCO (2015) Dossiê ABRASCO um alerta sobre os impactos dos agrotóxicos na saúde/ Organização Carneiro FF, Rigotto RM, Augusto LGS, Freidrich K, Búrgico AC. Associação brasileira de saúde coletiva - ABRASCO. EPSJV Rio de Janeiro.

Aktar MW, Sengupta D, Chowdhury A (2009) Impact of pesticides use in agriculture: their benefits and hazards. Interdisciplinary Toxicology. 2:1-13.

Allan E, Weisser WW, Fischer M, Schulze ED, Weigelt A, Roscher C, Baade J, Barnard RL, Beßler H (2013) A comparison of the strength of biodiversity effects across multiple functions. Oecologia, 173: 223-237.

Almeida S, Louzada J, Sperber C, Barlow J (2011) Subtle land-use change and tropical biodiversity: dung beetle communities in Cerrado grasslands and exotic pastures. Biotropica. 43:704-710.

Almeida-Neto M, Guimarães P, Guimarães Jr PR, Loyola RD, Ulrich W (2008) A consistente metric for nestedness analysis in ecological systems: reconciling concept and measurement. Oikos. 117:1227-1239.

Andersen MJ, Walsch DCI (2013) PERMANOVA, ANOSIM, and the Mantel test in the face of heterogeneous dispersions: What null hypothesis are you testing? Ecological Monographs. 83:557-574.

Anderson MJ (2001) A new method for non-parametric multivariate analysis of variance. Austral Ecology. 26:32-46.

Armbrecht I, Gallego MC (2007) Testing ant predation on the coffee berry borer in shaded and sun coffee plantations in Colombia. Entomologia Experimentalis et Applicata. $124: 261-267$ 
Armbrecht I, Perfecto I (2003) Litter-twig dwelling ant species richness and predation potential within a forest fragment and neighboring coffee plantations of contrasting habitat quality in Mexico. Agriculture Ecosystems \& Environment. 97:107-115.

Armbrecht I, Perfecto I, Silverman E (2006) Limitation of nesting resources for ants in Colombian forests and coffee plantations. Ecological Entomology. 31:403-410.

Atmar W, Patterson BD (1993) The measure of order and disorder in the distribution of species in fragmented habitat. Oecologia. 96: 373-382.

Baccaro FB, Feitosa RM, Fernandez F, Fernandes IO, Izzo TJ, de Souza JLP, Solar R (2015) Guia para os gêneros de formigas do Brasil. INPA, Manaus.

Balmford A, Green R, Phalan B (2012) What conservationists need to know about farming. Proc Biol Sci. 279:2714-2724.

Balvanera P, Pfisterer AB, Buchmann N, He JS, Nakashizuka T, Raffaelli D, Schmid B (2006) Quantifying the evidence for biodiversity effects on ecosystem functioning and services. Ecology letters. 9:1146-1156.

Balzan MV, Bocci G, Moonen AC (2016) Landscape complexity and field margin vegetation diversity enhance natural enemies and reduce herbivory by Lepidoptera pests on tomato crop. BioControl. 61:141-154.

Barnosky AD, Matzke N, Tomiya S, Wogan GOU, Swartz B, Quental TB, Marshall C, McGuire JL, Lindsey EL, Maguire KC, Mersey B, Ferrer EA (2011) Has the Earth's sixth mass extinction already arrived? Nature. 471:51-57.

Barton PS, Sato CF, Kay GM, Florance D, Lindenmayer DB (2016) Effects of environmental variation and livestock grazing on ant community structure in temperate eucalypt woodlands. Insect Conservation and Diversity. 9:124-134.

Baselga A (2010) Partitioning the turnover and nestedness components of beta diversity. Global Ecology and Biogeography. 19:134-143. 
Baselga A, Leprieur F (2015) Comparing methods to separate components of beta diversity. Methods in Ecology and Evolution. 6:1069-1079.

Belchior C, Del-Claro K, Oliveira PS (2012) Seasonal patterns in the foraging ecology of the harvester ant Pogonomyrmex naegelii (Formicidae, Myrmicinae) in a Neotropical savanna: daily rhythms, shifts in granivory and carnivory, and home range. ArthropodPlant Interactions. 6:571-582.

Belsley, D. A., Kuh, E. \& Welsch, R. E. (1980). Regression Diagnostics: Identifying Influential Data and Sources of Collinearity. New York: John Wiley.

Benayas LMR, Newton AC, Diaz A, Bullock JM (2009) Enhancement of Biodiversity and Ecosystem Services by Ecological Restoration: A Meta-Analysis. Science. 325:12211224.

Bestelmeyer BT, Wiens JA (1996) The effects of land use on the structure of ground-foraging ant communities in the Argentine chaco. Ecological Applications. 6:1225-1240.

Bestelmeyer BT, Wiens JA (2001) Ant Biodivesity in Semiarid Landscape Mosaics: The consequences of grazing vs. natural heterogeneity. Ecological Applications. 11:1231140.

Bihn JH, Gebauer G, Brandl R (2010) Loss of functional diversity of ant assemblages in secondary tropical forests. Ecology. 91:782-792.

Biofach (2016) Brazilian organic market trends and news. Organizador Ming Liu. IPD/Organics Brasil.

Birkhofer K, Arvidsson F, Ehlers D, Mader VL, Bengtsson J, Smith HG (2016) Organic farming affects the biological control of hemipteran pests and yields in spring barley independent of landscape complexity. Landscape Ecology. 31:567-579. 
Blanc J (2009) Family farmers and major retail chains in the Brazilian organic sector: Assessing new development pathways. A case study in a peri-urban district of São Paulo. Journal of Rural Studies. 25:322-332.

Bolton B, Alpert G, Ward PS, Naskrecki P (2007) Bolton's catalogue of ants of the world: 1758-2005. Harvard University Press, MA Cambridge.

Bommarco R, Lindborg R, Marini L, Öckinger E (2014) Extinction debt for plants and flower-visiting insects in landscapes with contrasting land use history. Diversity and Distributions. 20:591-599.

Boyer AG, Jetz W (2014) Extinctions and the loss of ecological function in island bird communities. Global Ecology and Biogeography. 23:679-688.

Brandão CRF, Silva RR, Feitosa RM (2011) Cerrado ground-dwelling ants (Hymenoptera: Formicidae) as indicators of edge effects. Zoologia. 28:379-387.

Brandão CRF, Siva RR, Delabie JHC (2012) Neotropical Ants (Hymenoptera) Functional Groups: Nutritional and Applied Implications. Editores: Panizzi AR, Parra JRP. Insect Bioecology and Nutrition for Integrated Pest Manegement. CRC Press. Boca Roton NW.

Brannstrom C, Jepson W, Filippi AM, Redo D, Xu ZW, Ganesh S (2008) Land change in the Brazilian Savanna (Cerrado), 1986-2002: Comparative analysis and implications for land-use policy. Land Use Policy. 25:579-595.

Brittain C, Potts SG (2011) The potential impacts of insecticides on the life-history traits of bees and the consequences for pollination. Basic and Applied Ecology. 12:321-331.

Brown-Jr KS, Gifford DR (2002) Lepidoptera in the Cerrado Landscape and the Conservation of Vegetation, Soil, and Topographical Mosaics. Editores: Oliveira PS, Marquis RJ. The Cerrados of Brazil: Ecology and Natural History of a Neotropical Savanna. Columbia University Press, New York. 
Bueno RCOF, Bueno AF, Moscardi F, Parra JRP, Hoffmann-Campo CB (2011) Lepidopteran larva consumption of soybean foliage: basis for developingmultiple-species economic thresholds for pestmanagement decisions. Pest Management Science. 67: 170-174.

Cadotte MW, Dinnage R, Tilman D (2012) Phylogenetic diversity promotes ecosystem stability. Ecology. 93: 223-233.

Campos RI, Vasconcelos HL, Andersen AN, Frizzo TLM, Spena KC (2011) Multi-scale ant diversity in savanna woodlands: an intercontinental comparison. Austral Ecology. 36:983-992.

Cardinale BJ, Srivastava DS, Duffy JE, Wright JP, Downing AL, Sankaran M, Jouseau C (2006) Effects of biodiversity on the functioning of trophic groups and ecosystems. Nature. 443:989-992.

Cavalcanti RB, Joly CA (2002) Biodiversity and conservation priorities in the Cerrado region. Pp 351-367 in P. S. Oliveira, and R. J. Marquis, editors. The Cerrados of Brazil: Ecology and Natural History of a Neotropical Savanna. Columbia University Press, New York.

Chapin FS, Zavaleta ES, Eviner VT, Naylor RL, Vitousek PM, Reynolds HL, Hooper DU, Lavorel S, Sala OE, Hobbie SE, Mack MC, Diaz S (2000) Consequences of changing biodiversity. Nature. 405:234-242.

Chrisman JR, Koifman S, Sarcinelli PN, Moreira JC,Koifman RJ, Meyer A (2009) Pesticide sales and adult male cancer mortality in Brazil. Int J Hyg Environ Health. 212:310321.

Colwell RK (2013) EstimateS: Statistical estimation of species richness and shared species from samples. Version 9. Persistent URL <purl.oclc.org/estimates>. 
Costa AN, Vasconcelos HL, Vieira-Neto EHM, Bruna EM (2008) Do herbivores exert topdown effects in Neotropical savannas? Estimates of biomass consumption by leafcutter ants. Journal of Vegetation Science. 19: 849-854.

Cuautle M, Vergara CH, Badano EI (2016) Comparison of Ant Community Diversity and Functional Group Composition Associated to Land Use Change in a Seasonally Dry Oak Forest. Neotropical Entomology. 45:170-179.

Cuezzo F (2003) Subfamilia Dolichoderinae. In: (Ed) Fernández F. Idroducción a las Hormigas de la Región Neotropical. Instituto de Investigación de Recursos Biológicos Alexander von Humboldt, Bogotá.

Daily GC, Alexander A, Ehrlich PR, Goulder L, Lubchenco J, Matson PA, Mooney HA, Postel S, Schnneider SH, Tilman D, Woodwell GM (1997) Ecosystem Services: Benefits Supplied to Human Societies by Natural Ecosystems. Issues in Ecology. 2:116.

De-Fries RS, Foley JA, Asner GP (2004) Land-use choices: balancing human needs and ecosystem function. Frontiers in Ecology and Envirnment. 2:249-257.

De-Groot RS (1992) Functions of Nature: Evaluation of Nature in Environmental Planning, Management and Decision Making. Wolters-Noordhoff, Groningen.

De-Groot RS, Wilson MA, Boumans RMJ (2002) A typology for the classification, description and valuation of ecosystem functions, goods and services. Ecological Economics. 41:393-408.

Delabie, J. H. 2001. Trophobiosis between Formicidae and Hemiptera (Sternorrhyncha and Auchenorrhyncha): an overview. Neotropical Entomology. 30:501-516.

Del-Claro K, Marquis RJ (2015) Ant Species Identity has a Greater Effect than Fire on the Outcome of an Ant Protection System in Brazilian Cerrado. Biotropica. 47:459-467. 
Didham RK, Ghazoul J, Stork NE, Davis AJ (1996) Insects in fragmented forests: a functional approach. Trends in Ecology \& Evolution. 11:255-260.

Diehl E, Sanhudo CED, Diehl-Fleig ED (2004) Ground-dwelling ant fauna of sites with high levels of copper. Brazilian Journal of Biology. 64:33-39.

Duffy JE (2009) Why biodiversity is important to the functioning of real-world ecosystems. Frontiers in Ecology and the Environment. 7:437-444.

Dufrêne M, Legendre P (1997) Species assemblages and indicator species: the need for a flexible asymmetrical approach. Ecological Monographs. 67:345-366.

Durães R, Martins WP, Vaz-De-Mello FZ (Dung Beetle (Coleoptera: Scarabaeidae) Assemblages across a Natural Forest-Cerrado Ecotone in Minas Gerais, Brazil. Ecology, Behavior and Bionomics. 34:721-731.

Ehrlich PR (2002) Human Natures, Nature Conservation, and Environmental Ethics. BioScience. 52: 31-43.

Fahrig L (2003) Effects of habitat fragmentation on biodiversity. Annual Review of Ecology Evolution and Systematics. 34:487-515.

FAO (2009) State of Food Insecurity in the World. Food and Agriculture Organization of the United Nations. Rome, Italy.

Farji-Brener AG, Corley JC (2002) The effects of fire on ant communities in northwestern Patagonia: The importance of habitat structure and regional context. Diversity and Distribution. 8:235-243.

Fayle TM, Bakker L, Cheah C, Ching TM, Davey A, Dem F, Earl A, Huaimei Y, Hyland S, Johansson B, Ligtermoet E, Lim R, Lin LK, Luangyotha P, Martins BH, Palmeirim AF, Paninhuan S, Rojas SK, Sam L, Sam PTT, Susanto D, Wahyudi A, Walsh J, Weigl S, Craze PG, Jehle R, Metcalfe D, Trevelyan R (2011) A positive relationship between ant biodiversity (Hymenoptera: Formicidae) and rate of scavenger-mediated 
nutrient redistribution along a disturbance gradient in a southeast Asian rain forest. Myrmecological News. 14:5-12.

Fearnside PM (2001) Soybean cultivation as a threat to the environment in Brazil. Environmental Conservation. 28:23-38.

Fernández F (2003) Introducción a las hormigas de la región Neotropical. Instituto de Investigación de Recursos Biológicos Alexander von Humboldt. Bogota

Ferreira AV, Bruna EM, Vasconcelos HL (2011) Seed predators limit plant recruitment in Neotropical savannas. Oikos. 120:1013-1022.

Ferreira LG, Yoshioka H, Huete Y, Sano EE (2004) Optical characterization of the Brazilian savanna physiognomies for improved land cover monitoring of the cerrado biome: preliminary assessments from an airborne campaign over an LBA core site. Journal of Arid Environments. 56:425-447.

Fittkau EJ, Klinge H (1973) On biomass and trophic structure of the central Amazonian rain forest ecosystem. Biotropica. 5:2-14.

Flynn DFB, Gogol-Prokurat M, Nogeire T, Molinari N, Richers BT, Lin BB, Simpson N, Mayfield MM, DeClerck F (2010) Loss of functional diversity under land use intensification across multiple taxa. Ecology Letters. 12:22-33.

Folgarait PJ (1998) Ant biodiversity and its relationship to ecosystem functioning: a review. Biodiversity and Conservation. 7: 1221-1244.

Frizzo TLM, Campos RI, Vasconcelos HL (2012) Contrasting Effects of Fire on Arboreal and Ground-Dwelling Ant Communities of a Neotropical Savanna. Biotropica. 44:254261.

Frizzo TLM, Vasconcelos HL (2013) The Potential Role of Scattered Trees for Ant Conservation in an Agriculturally Dominated Neotropical Landscape. Biotropica. 45: $644-651$. 
Fusaro S, Gavinelli F, Sommaggio D, Paoletti MG (2016) Higher efficiency in organic than in conventional management of biological control in horticultural crops in north-eastern Italy. Biological Control. 97:89-101.

Galen C (2005) Catching ants with honey: an experimental test of distraction and satiation as alternative modes of escape from flower-damaging ants. Oecologia. 144:80-7.

Gibb H, Parr CL (2010) How does habitat complexity aff ect ant foraging success? A test using functional measures on three continents. Oecologia. 164:1061-1073.

Gibb H, Stoklosa J, Warton DI, Brown AM, Andrew NR, Cunningham SA (2015) Does morphology predict trophic position and habitat use of ant species and assemblages? Oecologia. 177:519-531.

Gonthier DJ, Ennis KK, Philpott SM, Vandermeer J, Perfecto I (2013) Ants defend coffee from berry borer colonization. BioControl. 58:815-820.

Gotelli NJ, Ellison AM (2011) Princípios de estatística em ecologia. Tradução: Fabrício Beggiato Baccaro. Artmed. Porto Alegre.

Gray CL, Lewis OT, Chung AYC, Fayle TM (2015) Riparian reserves within oil palm plantations conserve logged forest leaf litter ant communities and maintain associated scavenging rates. Journal of Applied Ecology. 52:31-40.

Gregory Jr B (1989) Field observations of mating, oviposition, and feeding behavior of Anticarsia gemmatalis (Lepidoptera: Noctuidae) in a soybean field. Journal of Insect Behavior. 2:761-774.

Groom MJ, Gray EM, Townsend AA (2008) Biofuels and Biodiversity: Principles for Creating Better Policies for Biofuel Production. Conservation Biology. 22:602-609.

Groot AT Dicke M (2002) Insect-resistant transgenic plants in a multi-trophic context. Plant Journal. 31: 387-406. 
Gurr GM, Wratten SD, Luna JM (2003) Multi-function agricultural biodiversity: pest management and other benefits. Basic and Applied Ecology. 4:107-116.

Haddad NM, Crutsinger GM, Gross K, Haarstad J, Knops JM, Tilman D (2009). Plant species loss decreases arthropod diversity and shifts trophic structure. Ecology Letters. 12: 1029-1039.

Hall A, Mogyorody V (2001) Organic farmers in Ontario: an examination of the conventionalisation argument. Soc Ruralis. 41:399-422.

Harterreiten-Souza ES, Togni PHB, Milane PVGN, Cavalcante KR, Medeiros MA, Pires CSS, Sujii ER (2012) Seasonal fluctuation in the population of Harmonia axyridis (Pallas, 1773) (Coleoptera: Coccinellidae) and co-occurrence with other Coccinellidae in the Federal District of Brazil. Papéis Avulsos de Zoologia. 52:133-139.

Harterreiten-Souza ES, Togni PHB, Pires CSS, Sujii ER (2014) The role of integrating agroforestry and vegetable planting in structuring communities of herbivorous insects and their natural enemies in the Neotropical region. Agroforest Systems. 88:205-2019.

Hausberger B, Korb J (2016) The Impact of Anthropogenic Disturbance on Assembly Patterns of Termite Communities. Biotropica. 48:356-364.

Hernandez JV, Jaffé K (1995) Dano econômico causado por populações de formigas Atta laevigata (F. Smith) em plantações de Pinus caribaea Mor. e elementos para o manejo de praga. An Soc Entomol Brasil. 24: 287-298.

Hoffmann BD, Andersen AN (2003) Responses of ants to disturbance in Australia, with particular reference to functional groups. Austral Ecology. 28, 444-464.

Hoffmann WA, Lucatelli VMPC, Silva FJ, Azeuedo INC, Marinho MS, Albuquerque ANS, Lopes AO, Moreira SP (2004) Impact of the invasive alien grass Melinis minutiflora at the savanna-forest ecotone in the Brazilian Cerrado. Diversity and Distributions. 10:99-103. 
Hoffmann WA, Orthen B, Nascimento PKV (2003) Comparative fire ecology of tropical savanna and forest trees. Functional Ecology. 17:720-726.

Hole DG, Perkins AJ, Wilson JD, Alexander IH, Grice PV, Evans AD (2005) Does organic farming benefit biodiversity? Biological Conservation. 122:113-130.

Hollander M, Wolfe DA (1973) Nonparametric Statistical Methods. John Wiley \& Sons. New York.

Hölldobler B, Lumsden DJ (1980) Territorial Strategies in Ants. Science. 210:732-739.

Hölldobler B, Wilson EO (2009) The Superorganism: The Beauty, Elegance, and Strangeness of Insect Societies. W. W. Norton \& Company Inc, New York.

Hooper DU, Chapin III FS, EwelJJ, Hector A, Inchausti P, Lavorel S, Lawton JH, Lodge DM, Loreau M, Naeem S, Schmid B, Setala H, Symstad AJ, Vandermeer J, Wardle DA (2005) Effects of biodiversity on ecosystem functioning: a consensus of current knowledge. Ecological Monographs. 75:3-35.

Howe A, Lövei GL, Nachman G (2009) Dummy caterpillars as a simple method to assess predation rates on invertebrates in a tropical agroecosystem. Entomologia Experimentalis et Applicata. 131:325-329.

Hunter MD (2009) Trophic promiscuity, intraguild predation and the problemof omnivores. Agricultural and Forest Entomology. 11:125-131.

IPD (2010) Perfil do mercado orgânico brasileiro como processo de inclusão social. Instituto de Promoção do Desenvolvimento. IPD orgânicos, Curitiba.

IWMI (2007) Water for food, water for life: a comprehensive assessment of water management in agriculture. Earthscan and Colombo. International Water Management Institute, London

Jepson W (2005) A disappearing biome? Reconsidering land-cover change in the Brazilian savanna. Geographical Journal. 171:99-111. 
Jones DT, Susilo FX, Bignell DE, Hardiwinoto S, Gillison AN, Eggleton P (2003) Termite assemblage collapse along a land-use intensification gradient in lowland central Sumatra, Indonesia. Journal of Applied Ecology. 40:380-391.

Karban R, Mata TM, Grof-Tisza P, Crutsinger G, Holyoak MA (2013) Non-trophic effects of litter reduce ant predation and determine caterpillar survival and distribution. Oikos. $122: 1362-1370$.

Kaspari M. Yanoviak SP, Dudley R (2008) On the biogeography of salt limitation: a study of ant communities. Proceedings of the National Academy of Scienes of the United States of America. 105:17848-17851.

Kaspariz M, Yanovlak SP (2001) Bait Use in Tropical Litter and Canopy Ants-Evidence of Differences in Nutrient Limitation. Biotropica. 33:207-211.

Kessler M, Abrahamczyk S, Bos M, Buchori D, Putra DD, Gradstein SR, Hohn P, Kluge J, Orend F, Pltopang R, Saleh S, Schulze CH, Sporn SG, Steffan-Dewenter I, Tjitrosoedirdjo SS, Tscharntke T (2009) Alpha and beta diversity of plants and animals along a tropical land-use gradient. Ecological Applications. 19:2142-2156.

Klink CA, Machado RB (2005) Conservation of the Brazilian Cerrado. Conservation Biology. 19:707-713.

Klink CA, Moreira AG (2002) Past and current human occupation, and land use. Pp 69-88 in P. S. Oliveira, \& R. J. Marquis, editors. The Cerrados of Brazil: Ecology and Natural History of a Neotropical Savanna. Columbia University Press, New York.

Köppen W (1948) Climatologia: con un estudio de los climas de la tierra. Fondo de Cultura Econômica, México.

Kremen C (2005) Managing ecosystem services: what do we need to know about their ecology? Ecology Letters. 8:468-879. 
Landis DA, Wratten SD, Gurr GM (2000) Habitat management to conserve natural enemies of arthropod pests in agriculture. Annual Review of Entomology. 45:175-201.

Langellotto GA, Denno RF (2004) Responses of invertebrate natural enemies to complexstructured habitats: a meta-analytical synthesis. Oecologia. 139:1-10.

Larsen TH, Williams NM, Kremen C (2005) Extinction order and altered community structure rapidly disrupt ecosystem functioning. Ecology Letters. 8:538-547.

Layman CA, Araujo MS, Boucek R, Hammerschlag-Peyer CM, Harrison E, Jud ZR, Matich P, Rosenblatt A, Vaudo JJ, Yeager L, Post DM Bearhop S (2011) Applying stable isotopes to examine food web structure: an overview of analytical tools. Biological Reviews. 87: 545-562.

Lemessa D, Hambäck PA, Hylander K (2015) The effect of local and landscape level land-use composition on predatory arthropods in a tropical agricultural landscape. Landscape Ecology. 30:167-180.

Letourneau DK, Armbrecht I, Rivera BS, Lerma JM, Carmona EJ, Daza MC, Escobar S, Galindo V, Gutiérrez C, López SD, Mejía JL, Rangel AMA, Rangel J H, Rivera L, Saavedra CA, Torres AM, Trujillo AR (2010) Does plant diversity benefit agroecosystems? A synthetic review. Ecological Applications. 21:9-21.

Lieri H, Kim TN, Werling BP, Meehan TD, Landis DA, Gratton C (2015) Trophic cascades in agricultural landscapes: indirect effects of landscape composition on crop yield. Ecological Applications. 25:652-661.

Lingren PD, Greene GL, Davis DR, Baumhover AH, Henneberry TJ (1977) Nocturnal Behavior of Four Lepidopteran Pests That Attack Tobacco and Other Crops. Annals of the Entomological Society of America. 161-167. 
Lopes CT, Vasconcelos HL (2008) Evaluation of Three Methods for Sampling GroundDwelling Ants in the Brazilian Cerrado. Ecology, Behavior and Bionomics. 37:399405 .

López R, Potter DA (2000) Ant Predation on Eggs and Larvae of the Black Cutworm (Lepidoptera: Noctuidae) and Japanese Beetle (Coleoptera: Scarabaeidae) in Turfgrass. Environmental Entomology. 29:116-125.

Loreau M, Naeem S, Inchausti P, Bengtsson J, Grime JP, Hector A, Hooper DU, Huston MA, Raffaelli S, Schmid B, Tilman D, Wardle DA (2008) Biodiversity and Ecosystem Functioning: Current Knowledge and Future Challenges. Science. 294:804-808.

Lu Z, Hoffmann BD, Chen Y (2016) Can reforested and plantation habitats effectively conserve SW China's ant biodiversity? Biodiversyt and Conservation. 25:753-770.

Lumley T (2009) Package leaps: regression subset selection. $\mathrm{R}$ package version 2.9. http://CRAN.R-project.org/package=leaps

Lundgren JG (2009) Nutritional aspects of non-prey foods in the life histories of predaceous Coccinellidae. Biological Control. 51:294-305.

Machado RB, Neto MBR, Pereira PGP, Caldas EF, Gonçalves DA, Santos NS, Tabor K, Steininger M (2004) Estimativas de perda da área do Cerrado brasileiro. Relatório técnico não publicado. Conservação Internacional, Brasília - DF.

MAPA (2016a) Ministério da Agricultura Pecuária e Abastecimento. (documento on line) http://www.agricultura.gov.br/arq_editor/Pasta\%20de\%20Maio\%20-\%202016.pdf /Acessado em: 24/06/2016

MAPA (2016b) Ministério da Agricultura Pecuária e Abastecimento. (documento on line) http://www.agricultura.gov.br/vegetal/culturas/soja /Acessado em: 24/06/2016 
MAPA (2016c) Ministério da Agricultura Pecuária e Abastecimento. (documento on line)http://www.agricultura.gov.br/comunicacao/noticias/2015/09/mercado-brasileirode-organicos-deve-movimentar-rs-2-bi-em-2016 /Acessado em: 24/06/2016

Maravalhas J, Vasconcelos HL (2014) Revisiting the pyrodiversity-biodiversity hypothesis: long-term fire regimes and the structure of ant communities in a Neotropical savanna hotspot. Journal of Applied Ecology. 51:1661-1668.

Marichal R, Grimaldi M, Feijo AM, Oszwald J, Praxedes C, Cobo MHR, Hurtado MP, Desjardins T, Silva-Junior ML, Costa LGS, Miranda IS, Oliveira MND, Brownh J, Tsélouikoa S, Martins MB, Decaëns T, Velasquez E, Lavelle P (2014) Soil macroinvertebrate communities and ecosystem services indeforested landscapes of Amazonia. Applied Soil Ecology. 83:177-185.

Mata RA. Tidon R (2013) The relative roles of habitat heterogeneity and disturbance in drosophilid assemblage (Diptera, Drosophilidae) in the Cerrado. Insect Conservation and Diversity. 6:663-670.

McKinney ML, Lockwood JL (1999) Biotic homogenization: a few winners replacing many losers in the next mass extinction. Trends in Ecology \& Evolution. 14:450-453.

Mensens C, Frederik De Laender, Colin R. Janssen, Koen Sabbe and Marleen De Troch Stressor-induced biodiversity gradients: revisiting biodiversity-ecosystem functioning relationships. Oikos. 124:677-684.

MMA (2016) Ministério do Meio Ambiente. (documento on line) http://www.mma.gov.br/seguranca-quimica/agrotoxicos_Acessado em: 24/06/2016

Mora C, Tittensor DP, Adl S, Simpson AGB, Worm B. 2011. How Many Species Are There on Earth and in the Ocean? PLoS Biology. 9:e1001127.

Myers N, Mittermeier RA, Mittermeier CG, Da Fonseca GA, Kent J (2000) Biodiversity hotspots for conservation priorities. Nature. 403: 853-858. 
Naranjo SE (2001) Conservation and evaluation of natural enemies in IPM systems for Bemisia tabaci. Crop Protection. 20:835-852.

Newbold T, Hudson LH, Hill SLL, Contu S, Lysenko I, Senior RA, Börger L, Bennett DJ, Choimes A, Collen B, Day J, De Palma A, Díaz S (2015) Global effects of land use on local terrestrial biodiversity. Nature. 520: 45-50.

Offenberg J (2015) Ants as tools in sustainable agriculture. Journal of Applied Ecology. 52: $1197-1205$.

Oksanen J, Blanchet FG, Kindt R, Legendre P, Minchin PR, O'Hara RR, Simpson GL, Solymos P, Henry M, Stevens H, Wagner H (2015) vegan: Community Ecology Package. R package version 2.3-1. http://CRAN.R-project.org/package=vegan

Oliveira-Filho T, Ratter JA (2002) Vegetation physiognomies and woody flora of the Cerrado Biome. Pp 91-120 in P. S. Oliveira, \& R. J. Marquis, editors. The Cerrados of Brazil Ecology and Natural History of a Neotropical Savanna. Columbia University Press, New York.

Pacheco R, Vasconcelos HL (2012) Habitat diversity enhances ant diversity in a naturally heterogeneous Brazilian landscape. Biodiversity and Conservation. 21:797-809.

Pacheco R, Vasconcelos HL, Groc S, Camacho GP, Frizzo TLM (2013) The importance of remnants of natural vegetation for maintaining ant diversity in Brazilian agricultural landscapes. Conservation Biology. 22: 983-997.

Parra JR, Zucchi RA (2004) Trichogramma in Brazil: feasibility of use after twenty years of research. Neotropical Entomology. 33:271-281.

Perfecto I, Vandermeer J (2002) Quality of Agroecological Matrix in a Tropical Montane Landscape: Ants in Coffee Plantations in Southern Mexico. Conservatio Biology. 16:174-182. 
Perfecto I, Vandermeer JH, Bautista GL, Nunez GI, Greenberg R, Bichier P, Langridges S (2004) Greater predation in shaded coffee farms: the role of resident neotropical. Ecology. 85:2677-2681.

Pereira JL, Picanc MC, Pereira EJG, Silva AA, Jakelaitis A, Pereira RR, Xavier VM (2010) Influence of crop management practices on bean foliage arthropods. Bulletin of Entomological Research. 100:679-688.

Philpott SM, Arendt WJ, Armbrecht I, Bichier P, Diestch TV, Gordon C, Greenberg R, Perfecto I, Reynoso-Santos R, Soto-Pinto L, Tejeda-Cruz C, Williams-Linera G, Valenzuela J, Zolotoff JM (2008) Biodiversity Loss in Latin American Coffee Landscapes: Review of the Evidence on Ants, Birds, and Trees. Conservation Biology. 22:1093-1105.

Philpott SM, Armbrecht I (2006) Biodiversity in tropical agroforests and the ecological role of ants and ant diversity in predatory function. Ecological Entomology. 31:369-377.

Philpott SM, Foster PF (2005) Nest-site limitation in coffe agroecosystems: Artificial nests maintain diversity of arboreal ants. Ecologial Aplication. 15:1478-1485.

Pimental D, Stachow U, Takacs A, Brubaker W, Dumas AR, Meaney JS et al. (1992) Conserving biological diversity in agricultural/forestry systems. Bioscience. 432:354362.

Pimm SL, Russell GJ, Gittleman JL, Brooks TM (1995) The future of biodiversity. Science. 269:347-350.

Pinheiro F, Diniz IR, Coelho D, Bandeira MPS (2008) Seasonal pattern of insect abundance in the Brazilian Cerrado. Austral Ecology. 27:132-136.

Pivello VR, Shida CN, Meirelles ST (1999) Alien grasses in Brazilian savannas: a threat to the biodiversity. Biodiversity and Conservation. 8:1281-1294. 
Pohlert T (2014). The Pairwise Multiple Comparison of Mean Ranks Package (PMCMR). R package, <URL:http://CRAN.R-project.org/package=PMCMR>.

Popp J, Pető K, Nagy J (2013) Pesticide productivity and food security. A review. Agron. Sustain. Dev. 33:243-255.

Price PW, Diniz IR, Morais HC, Marques ESA (1995) The abundance of insect herbivore species in the tropics: the hight local richness of rare species. Biotropica. 27: 468-478.

R Development Core Team (2008). R: A language and environment for statistical computing. R Foundation for Statistical Computing, Vienna, Austria. ISBN 3-900051-07-0, URL http://www.R-project.org.

Redford KH, Fonseca GAB (1986) The role of gallery forests in the zoogeography of the Cerrado's non-volant mammalian fauna. Biotropica. 18:126-135.

Ribas CR, Campos RBF, Schmidt FA, Solar RRC (2012) Ants as indicators in Brazil: A review with suggestions to improve the use of ants in envirnmental monitoring programs. Psyche. 2012:1-23.

Ribeiro-Neto JD, Arnan X, Tabarelli M, Leal IR (2016) Chronic anthropogenic disturbance causes homogenization of plant and ant communities in the Brazilian Caatinga. Biodiversyt and Conservation. 25:943-956.

Rigby D, Cáceres D (2001) Organic farming and the sustainability of agricultural systems. Agricultural systems. 68: 21-40.

Risch SJ, Carroll CR (1982) Effect of a keystone predaceous ant, solenopsis-geminata, on arthropods in a tropical agroecosystem. Ecology. 63:1979-1983.

Roberts DW (2016). labdsv: Ordination and Multivariate Analysis for Ecology. R package version 1.8-0. http://CRAN.R-project.org/package=labdsv

Rockström J, Steffen W, Noone K, Persson A, Chapin FS, Lambin EF, Lenton TM, Scheffer M, Folke C, Schellnhuber HJ, Nykvist B, de Wit CA, Hughes T, Van der Leeuw S, 
Rodhe H, Sörlin S, Snyder PK, Costanza R, Svedin U, Falkenmark M, Karlberg L, Corell RW, Fabry VJ, Hansen J, Walker B, Liverman D, Richardson K, Crutzen P, Foley JA (2009) A safe operating space for humanity. Nature. 46:472-475.

Root RB (1973) Organization of a plant-arthropod association in simple and diverse habitats: the fauna of collards (Brassica oleraceae). Ecological Monography. 43:95-124.

Sakamoto Y, Ishiguro M, Kitagawa G (1986) Akaike Information Criterion Statistics. D. Reidel Publishing Company. Tokyo.

Sala OE, Chapin FS, Armesto JJ, Berlow E, Bloomfield J, Dirzo R, Huber-Sanwald R, Huenneke LF, Jackson RB, Kinzig A, Leemans R, Lodge DM, Mooney AH, Oesterheld M, Poff NL, Sykes MT, Walker BH, Walker M, Wall DH (2000) Biodiversity - Global biodiversity scenarios for the year 2100. Science. 287:17701774 .

Sanders D, Platner C (2007) Intraguild Interactions between Spiders and Ants and Top-Down Control in a Grassland Food Web. Oecologia. 150:611-624.

Sano EE, Rosa R, Brito JLS, Ferreira LG (2010) Land cover mapping of the tropical savanna region in Brazil. Environmental Monitoring and Assessment. 166:113-124.

Senior MJM, Hamer KC, Bottrell S, Edwards DP, Fayle TM, Lucey JM, Mayhew PJ, Newton R, Peh KSH, Sheldon FH, Stewart C, Styring AR, Thom MDF, Woodcock P, Hill JK (2013) Trait-dependent declines of species following conversion of rain forest to oil palm plantations. Biodiversity and Conservation. 22:253-268.

Silberman RE, Gordon D, Ingram KK (2016) Nutrient stores predict task behaviors in diverse ant species. Insectes Sociaux. 63:299-307.

Silva DP, Marco Jr P (2014) No evidence of habitat loss Affecting the Orchid Bees Eulaema nigrita Lepeletier and Eufriesea auriceps Friese (Apidae: Euglossini) in the Brazilian Cerrado Savanna. Ecology, Begavior and Bionomics. 43:509-518. 
Silva JF, Farinãs MR, Felfili JM, Klink CA (2006) Spatial heterogeneity, land use and conservation in the cerrado region of Brazil. Journal of Biogeography. 33:536-548.

Solar RRC, Barow J, Ferreira J, Berenguer E, Lees AC, Thomson JR, Louzada J, Maués M, Moura NG, Oliveira, VHF, Chaul JCM, Schoereder JH, Vieira ICG, Nally RM, Gardner TA (2015) How pervasive is biotic homogenization in human-modified tropical forest landscape? Ecology Letters. 18:1108-1118.

Srivastava D, Lawton J (1998) Why more productive sites have more species: an experimental test of theory using tree-hole communities. American Naturalist. 152: $510-529$.

Srivastava DS, Vellend M (2005) Biodiversity-Ecosystem Function Research: Is It Relevant to Conservation? Annual Review Ecology and Systematic. 36:267-294.

Styrsky JD, Eubanks MD (2007) Ecological consequences of interactions between ants and honeydew-producing insects. Proc R Soc B. 274:151-164.

Styrsky JD, Eubanks MD (2010) A facultative mutualism between aphids and an invasive ant increases plant reproduction. Ecological Entomology. 35:190-199.

Sujii ER, Venzon M, Medeiros MA, Pires CSS, Togni PHB (2010) Práticas culturais no manejo de pragas na agricultura orgânica. In: Venzon M, Júnior TJP, Pallini A (eds.) Controle alternativo de pragas e doenças na agricultura orgânica. EPAMIG, Viçosa

Suzuki R, Shimodaira H (2015). pvclust: Hierarchical Clustering with P-Values via Multiscale Bootstrap Resampling. $\mathrm{R}$ package version 2.0-0. http://CRAN.Rproject.org/package $=$ pvclust

Symondson WOC, Sunderland KD, Greenstone MH (2002) Can generalist predators be effective biocontrol agents? Annual Review Entomology. 47:561-594. 
Tiemann LK, Grandy AS, Atkinson EE, Marin-Spiotta E, McDaniel MD (2015) Crop rotational diversity enhances belowground communities and functions in an agroecosystem. Ecology Letters. 18:761-771.

Tobin JE (1994) Ants as primary consumers: diet and abundance in the Formicidae. In: Hunt JH \& Nalepa CA (eds.) Nourishment and Evolution in Insect Societies. Westview Press, Oxford.

Togni PHB, Venzon M, Muniz CA, Martins EF, Pallini A, Sujii ER (2016) Mechanisms underlying the innate attraction of an aphidophagous coccinellid to coriander plants: Implications for conservation biological control. Biological Control. 92:77-84.

Tscharntke T, Clough Y, Wanger TC, Jackson L, Motzke I, Perfecto I, et al. (2012) Global food security, biodiversity conservation and the future of agricultural intensification. Biological Conservation. 151:53-59.

Tscharntke T, Klein AM, Kruess A, Steffan-Dewenter I, Thies C (2005) Landscape perspectives on agricultural intensification and biodiversity - ecosystem service management. Ecology Letters. 8:857-874.

Uchida K, Ushimaru A (2014) Biodiversity declines due to abandonment and intensification of agricultural lands: patterns and mechanisms. Ecological Monographs. 84:637-658.

Ulysséa MA, Brandão CRF (2013) Ant species (Hymenoptera, Formicidae) from the seasonally dry tropical forest of northeastern Brazil: a compilation from field surveys in Bahia and literature records. Revista Brasileira de Entomologia. 57:217-224.

UNPD (2011) World population prospects: the 2010 revision. United Nations Population Division. New York: United Nations. Website https://ndb.nal.usda.gov/ndb/search. Acessado em: 20 maio de 2016.

USDA (2016) United States Department of Agriculture. Agriculture Reserch Service. USDA Food Composition Databases. Acessado em: 20 maio de 2016. 
Van der Plas F, Manning P, Soliveres S, Allana E, Scherer-Lorenzen M, Verheyen K, Wirth F, Zavalag MA, Ampoorterd E, Baeten L, Barbaro L, Bauhus J, Benavides R, Benneter A, Bonal D, Bouriaud O, Bruelheide H, Bussotti F, Carnol M, Castagneyrol B, Charbonnier Y, Coomes DA, Coppi A, Bestias CC, Dawud SM, Wandeler H, Domisch T, Finér L, Gessler A, Granier A, Grossiord C, Guyot V, Hättenschwiler S, Jactel H, Jaroszewicz B, Joly FX, Jucker T, Korichevaa J, Milligana H, Mueller S, Muyst B, Nguyenb D, Pollastrinio M, Ratcliffee S, Raulund-Rasmussens K, Selvi F, Stenlidb J, Valladares F, Vesterdal L, Zielínski D, Fische M (2016). Biotic homogenization can decrease landscape-scale forest multifunctionality. Proceedings of the National Academy of Sciences. 113:3557-3562.

Van Meerbeek K, Helsen K, Hermy M (2014) Impact of land-use intensity on the conservation of functional and phylogenetic diversity in temperatesemi-natural plant communities. Biodiversyt and Conservation. 23:2259-2272.

Vasconcelos HL, Frizzo TLM, Pacheco R, Maravalhas JB, Camacho GP, Carvalho KS, Koch EBA, Pujol-Luz JR (2014) Evaluating sampling sufficiency and the use of surrogates forassessing ant diversity in a Neotropical biodiversity hotspot. Ecological Indicators. 46:286-292.

Vasconcelos HL, Leite MF, Vilhena JMS, Lima AP, Magnusson WE. 2008. Ant diversity in an Amazonian savanna: Relationship with vegetation structure, disturbance by fire, and dominant ants. Austral Ecology. 33:221-231.

Veech JA, Summerville KS, Crist TO, Gering JC (2002) The additive partitioning of species diversity: recent revival of an old idea. Oikos. 99:3-9.

Vieira CR, Moraes MCB, Borges M, Sujii ER, Laumann RA (2013) cis-Jasmone indirect action on egg parasitoids (Hymenoptera: Scelionidae) and its application in biological 
control of soybean stink bugs (Hemiptera: Pentatomidae). Biological Control. 64:7582.

Vieira J, Vasconcelos HL (2014) Limitação por sódio em assembleia de formigas no Cerrado. Dissertação de mestrado. Programa de Pós-graduação em ecologia e conservação de recursos naturais. Instituto de Biologia. Universidade Federal de Uberlândia.

Wackernagel M, Onisto L, Bello P, Linares AC, Falfán ISL, García JM, Guerrero AIS, Guerrero MGS (1999) National natural capital accounting with the ecological footprint concept. Ecological Economics. 29:375-390.

Wake DB, Vredenburg VT (2008) Are we in the midst of the sixth mass extinction? A view from the world of amphibians. Proceedings of the National Academy of Sciences. 105: $11466-11473$

Wall SBV, Kuhn KM, Beck MJ (2005) Seed Removal, Seed Predation, And Secondary Dispersal. Ecology. 86:801-806.

Weiner CN, Werner M, Linsenmair KE, Blüthgen N (2014) Land-use impacts on plantpollinator networks: interaction strength and specialization predict pollinator declines. Ecology. 95:466-474.

Whittaker RH (1960) Vegetation of the Siskiyou Mountains, Oregon and California. Ecological Monographs. 30:279-338.

Whittaker RH (1972) Evolution and measurement of species diversity. Taxon. 21:213-251.

Winqvist C, Bengtsson J, Aavik T, Berendse F, Clement LW, Eggers S, Fischer C, Flohre A, Geiger F, Liira J, Pärt T, Thies C, Tscharntke T, Weisser WW, Bommarco R (2011) Mixed effects of organic farming and landscape complexity on farmland biodiversity and biological control potential across Europe. Journal of Applied Ecology. 48:570579. 
Zanetti R, Zanuncio JC, Santos JC, Silva WLP, Ribeiro GT, Lemes PG (2014) An Overview of Integrated Management of Leaf-Cutting Ants (Hymenoptera: Formicidae) in Brazilian Forest Plantations. Forests. 5:439-454.

Zehnder G, Gurr GM, Kühne S, Wade MR, Wratten SD, Wyss E (2007) Arthropod pest management in organic crops. Annual Reviews Entomology. 52:57-80. 
Anexo I.

Definição dos grupos funcionais e lista das respectivas espécies.

\begin{tabular}{|c|c|}
\hline Grupo funcional / Descrição & Espécies \\
\hline $\begin{array}{l}\text { Arborícola } \\
\text { Espécies que nidificam } \\
\text { obrigatoriamente em árvores e } \\
\text { arbustos. }\end{array}$ & $\begin{array}{l}\text { Azteca sp.01, Azteca sp.02, Cephalotes atratus, Cephalotes betoi, } \\
\text { Cephalotes maculatus, Cephalotes pusillus Crematogaster limata, } \\
\text { Crematogaster sp.01, Crematogaster sp.02, Crematogaster sp.03, } \\
\text { Crematogaster sp.04, Crematogaster sp.05, Crematogaster sp.06, } \\
\text { Crematogaster sp.08, Crematogaster } \mathrm{sp} .10 \text {, Crematogaster } \mathrm{sp} .11 \text {, } \\
\text { Crematogaster sp.13, Crematogaster } \mathrm{sp} .14 \text {, Pseudomyrmex } \mathrm{cf} . \\
\text { phyllophilus, Pseudomyrmex gracilis, Pseudomyrmex pallidus } \mathrm{e} \\
\text { Pseudomyrmex tenuis. }\end{array}$ \\
\hline $\begin{array}{l}\text { Attini } \\
\text { Tribo da subfamília Myrmicinae, } \\
\text { cuja as espécies cultivam fungo } \\
\text { em matéria vegetal recolhida } \\
\text { pelas operárias. Algumas destas } \\
\text { são consideradas pragas } \\
\text { agrícolas com as formigas do } \\
\text { gênero Atta e Acromyrmex. }\end{array}$ & $\begin{array}{l}\text { Acromyrmex cf. balzani, Acromyrmex sp.01, Acromyrmex sp.02, } \\
\text { Acromyrmex sp.03, Apterostigma sp.01, Apterostigma sp.02, Atta } \\
\text { sp.01, Cyatta abscondita, Cyphomyrmex lectus, Cyphomyrmex } \\
\text { rimosus, Cyphomyrmex sp.04 gr. rimosus, Cyphomyrmex sp.05 gr. } \\
\text { rimosus, Cyphomyrmex sp.06 gr. rimosus, Cyphomyrmex sp.09 gr. } \\
\text { strigatus, Cyphomyrmex sp.10 gr. strigatus, Mycetarotes cf. } \\
\text { parallelus, Mycetarotes sp.02, Mycocepurus goeldii, Mycocepurus } \\
\text { obsoletus, Mycocepurus sp.03, Mycocepurus sp.04, Myrmicocrypta } \\
\text { camargoi, Myrmicocrypta sp.01, Myrmicocrypta sp.03, Sericomyrmex } \\
\text { sp.01, Sericomyrmex sp.02, Trachymyrmex sp.01, Trachymyrmex } \\
\text { sp.02, Trachymyrmex sp.03, Trachymyrmex sp.04, Trachymyrmex } \\
\text { sp.05, Trachymyrmex sp.06, Trachymyrmex sp.07, Trachymyrmex } \\
\text { sp.08, Trachymyrmex sp.09 e Trachymyrmex sp.10. }\end{array}$ \\
\hline $\begin{array}{l}\text { Camponotini } \\
\text { Tribo da subfamília Formicinae, } \\
\text { representada aqui por um único } \\
\text { gênero, Camponotus. Esse grupo } \\
\text { apresenta espécies capazes de } \\
\text { nidificar no solo e/ou na } \\
\text { vegetação arbórea. Apresentam } \\
\text { um comportamento oportunista, } \\
\text { sendo facilmente encontradas em } \\
\text { interações mutualísticas com } \\
\text { afídeos. Porém, diferente do } \\
\text { grupo funcional oportunista } \\
\text { (com espécies de pequeno } \\
\text { porte), as espécies apresentam } \\
\text { um tamanho corporal de médio a } \\
\text { grande. }\end{array}$ & $\begin{array}{l}\text { Camponotus arboreus, Camponotus atriceps, Camponotus bidens, } \\
\text { Camponotus bonarensis, Camponotus cingulatus, Camponotus gr. } \\
\text { blandus, Camponotus gr. senex, Camponotus lespesii, Camponotus } \\
\text { leydigi, Camponotus novagrandensis, Camponotus personatus, } \\
\text { Camponotus renggeri, Camponotus rufipes, Camponotus } \\
\text { sericeiventris, Camponotus sp.12, Camponotus sp.17, Camponotus } \\
\text { sp.18, Camponotus sp.26, Camponotus sp.27, Camponotus sp.28, } \\
\text { Camponotus sp.29, Camponotus sp.30, Camponotus sp.32, } \\
\text { Camponotus sp.34, Camponotus sp.35, Camponotus sp.44, } \\
\text { Camponotus sp.45, Camponotus sp.16 e Camponotus substitutus. }\end{array}$ \\
\hline $\begin{array}{l}\text { Correição } \\
\text { Grupo de espécies nômades, que } \\
\text { forrageiam em grandes colunas } \\
\text { (muitos indivíduos, um ao lado } \\
\text { do outro) e são extremamente } \\
\text { vorazes, sendo encontrado na } \\
\text { literatura registros de predação } \\
\text { de até pequenos roedores. }\end{array}$ & $\begin{array}{l}\text { Eciton vagans, Labidus coecus, Labidus mars, Labidus praedator, } \\
\text { Neivamyrmex pseudops, Neivamyrmex sp.01, Neivamyrmex sp.02, } \\
\text { Neivamyrmex sp.04, Neivamyrmex sp.05, Neivamyrmex sp.06, } \\
\text { Neivamyrmex sp.07 e Nomamyrmex esenbeckii wilsoni. }\end{array}$ \\
\hline $\begin{array}{l}\text { Especialista } \\
\text { Grupo de espécies que } \\
\text { apresentam características }\end{array}$ & $\begin{array}{l}\text { Acanthosticus brevicornis, Acropyga } \mathrm{sp} .01, \text { Acropyga } \mathrm{sp} .02, \\
\text { Acropyga } \mathrm{sp} .03, \text { Basiceros } \mathrm{sp} .01, \text { Blepharidatta conops, Carebara } \\
\text { brevipilosa, Carebara urichi, Centromyrmex brachycola, }\end{array}$ \\
\hline
\end{tabular}


morfológicas ou ecológicas muito específicas. Em geral, sua frequência de registro é baixa, sendo a maioria de predadores especialistas de um determinado táxon.

\section{Generalista}

Grupo que contempla espécies onívoras e com grande plasticidade ecológica. A maioria das espécies nidificam no solo (ex: Pheidole spp.), porém algumas também conseguem nidificar na serapilheira, em galhos caídos e em árvores e arbustos.

Apresentam o comportamento de recrutar outros indivíduos da colônia quando encontram alimento. Participam deste grupo algumas espécies exóticas como: Cardiocondyla emeryi, Monomorium florícola e Tetramorium cf. similum.
Centromyrmex gigas, Dolichoderus bispinosus, Gnamptogenys acuminata, Gnamptogenys cf. bruchi, Gnamptogenys cf. rastrata, Gnamptogenys sp.01, Gnamptogenys sp.03, Gnamptogenys sp.06, Gnamptogenys sulcata, Heteroponera dolo, Hylomyrma sp.02, Hylomyrma sp.03, Hypoponera cf. foreli, Hypoponera sp.01, Hypoponera sp.03, Hypoponera sp.04, Hypoponera sp.05, Hypoponera sp.06, Hypoponera sp.07, Hypoponera sp.08, Megalomyrmex silvestrii, Megalomyrmex sp.02, Octostruma sp.01, Oxyepoecus $c f$. vezenyii, Oxyepoecus sp.02, Oxyepoecus sp.03, Pogonomyrmex naegile, Prionopelta punctulata, Prionopelta sp.02, Pseudomyrmex termitarius, Rasopone sp.01, Rogeria sp.01, Rogeria sp.02, Strumygenys sp.01, Strumygenys sp.02, Strumygenys sp.03, Strumygenys sp.04, Strumygenys sp.05, Strumygenys sp.06, Strumygenys sp.07 e Typhlomyrmex pusillus. Brachymyrmex cf. delabiei, Brachymyrmex pilipes, Brachymyrmex sp.01, Brachymyrmex sp.02, Brachymyrmex sp.03, Brachymyrmex sp.04, Brachymyrmex sp.05, Brachymyrmex sp.07, Brachymyrmex sp.08, Brachymyrmex sp.09, Brachymyrmex sp.10, Cardiocondyla emeryi, Cardiocondyla sp.01, Forelius sp.01, Forelius sp.02, Monomorium florícola, Nylanderia sp.01, Nylanderia sp.03, Nylanderia sp.04, Ochetomyrmex semipolitus, Pheidole gr. fimbriata, Pheidole sp.02, Pheidole sp.03, Pheidole sp.04, Pheidole sp.05, Pheidole sp.06, Pheidole sp.07, Pheidole sp.08, Pheidole sp.09, Pheidole sp.10, Pheidole sp.11, Pheidole sp.13, Pheidole sp.16, Pheidole sp.17, Pheidole sp.18, Pheidole sp.19, Pheidole sp.21, Pheidole sp.23, Pheidole sp.24, Pheidole sp.25, Pheidole sp.26, Pheidole sp.27, Pheidole sp.28, Pheidole sp.29, Pheidole sp.31, Pheidole sp.33, Pheidole sp.35, Pheidole sp.36, Pheidole sp.38, Pheidole sp.39, Pheidole sp.40, Pheidole sp.41, Pheidole sp.42, Pheidole sp.44, Pheidole sp.45, Pheidole sp.46, Pheidole sp.47, Pheidole sp.48, Pheidole sp.49, Pheidole sp.50, Pheidole sp.20, Pheidole sp.22, Solenopsis cf. loretana, Solenopsis globularia, Solenopsis sp.03, Solenopsis sp.04 pr. loretana, Solenopsis sp.08, Solenopsis sp.11, Solenopsis sp.12, Solenopsis sp.13, Solenopsis sp.14, Solenopsis sp.15, Solenopsis sp.16 gr. molesta, Solenopsis sp.17 gr. wasmannii, Solenopsis sp.18, Solenopsis sp.01, Solenopsis sp.02, Solenopsis tridens, Tapinoma sp.02, Tetramorium cf. similum, Wasmannia auropunctata, Wasmannia sp.02 e Wasmannia sp.03.

\section{Generalista dominante} Pheidole gertrudae, Pheidole sp.01 e Solenopsis saevissima.

Grupo composto por três espécies onívoras, que possuem a característica, devido ao grande recrutamento de indivíduos, de monopolizar o recurso encontrado frente aos demais competidores.

\section{Oportunista}

Grupo capaz de forragear nos períodos mais quentes do dia, e que geralemente não monopolizam a fonte de
Dorymyrmex cf. bituber, Dorymyrmex cf. brunneus, Dorymyrmex cf. jheringi, Dorymyrmex sp01, Dorymyrmex sp05, Linepithema $\mathrm{cf}$. cerradense, Linepithema cf. gallardoi, Linepithema cf. humile, Linepithema cf. neotropicum, Linepithema iniquum, Linepithema micans e Linepithema sp05. 


\begin{tabular}{|l|l|}
\hline $\begin{array}{l}\text { alimento diante de competidores, } \\
\text { apresentando um } \\
\text { comportamento conhecido como } \\
\text { insinuators. }\end{array}$ & \\
\hline $\begin{array}{l}\text { Predador grande } \\
\text { Espécies de grande porte, sendo } \\
\text { algumas predadoras } \\
\text { especialistas. }\end{array}$ & $\begin{array}{l}\text { Anochetus inermis, Dinoponera australis, Ectatomma brunneum, } \\
\text { Ectatomma edentatum, Ectatomma opaciventris, Ectatomma } \\
\text { permagnum, Ectatomma planidens, Ectatomma tuberculatum, } \\
\text { Neoponera marginata, Neoponera verenae, Odontomachus bauri, } \\
\text { Odontomachus chelifer, Odontomachus laticeps, Odontomachus } \\
\text { sp.05, Pachycondyla harpax, Pachycondyla sp.03 e Pachycondyla } \\
\text { striata. }\end{array}$ \\
\hline
\end{tabular}


Anexo II.

Lista de espécies amostradas no Capítulo I.

\begin{tabular}{|c|c|c|c|c|}
\hline & \multicolumn{2}{|c|}{ Agrossistemas } & \multicolumn{2}{|c|}{ Vegetação nativa } \\
\hline Subfamílias/Espécies & Ocorrências & $\begin{array}{l}\mathrm{N}^{\circ} \text { médio de } \\
\text { registros por } \\
\text { localidade }\end{array}$ & Ocorrências & $\begin{array}{l}\mathrm{N}^{\mathrm{o}} \text { médio de } \\
\text { registros por } \\
\text { localidade }\end{array}$ \\
\hline Dolichoderinae & 254 & 5,64 & 143 & 5,96 \\
\hline Azteca sp.01 & 0 & 0 & 4 & 0,17 \\
\hline Azteca sp.02 & 0 & 0 & 6 & 0,25 \\
\hline Dolichoderus bispinosus & 0 & 0 & 3 & 0,13 \\
\hline Dorymyrmex cf. bituber & 9 & 0,2 & 0 & 0 \\
\hline Dorymyrmex cf. brunneus & 112 & 2,49 & 3 & 0,13 \\
\hline Dorymyrmex cf. jheringi & 11 & 0,24 & 11 & 0,46 \\
\hline Dorymyrmex sp.01 & 20 & 0,44 & 7 & 0,29 \\
\hline Dorymyrmex sp.05 & 1 & 0,02 & 1 & 0,04 \\
\hline Forelius sp.01 & 3 & 0,07 & 3 & 0,13 \\
\hline Forelius sp.02 & 2 & 0,04 & 2 & 0,08 \\
\hline Linepithema cf. cerradense & 19 & 0,42 & 38 & 1,58 \\
\hline Linepithema cf. gallardoi & 3 & 0,07 & 15 & 0,63 \\
\hline Linepithema cf. humile & 9 & 0,2 & 13 & 0,54 \\
\hline Linepithema cf. neotropicum & 43 & 0,96 & 14 & 0,58 \\
\hline Linepithema iniquum & 0 & 0 & 1 & 0,04 \\
\hline Linepithema micans & 14 & 0,31 & 10 & 0,42 \\
\hline Linepithema sp.05 & 0 & 0 & 11 & 0,46 \\
\hline Tapinoma sp.02 & 8 & 0,18 & 1 & 0,04 \\
\hline Dorylinae & 29 & 0,64 & 35 & 1,46 \\
\hline Acanthosticus brevicornis & 0 & 0 & 1 & 0,04 \\
\hline Eciton vagans & 0 & 0 & 1 & 0,04 \\
\hline Labidus coecus & 16 & 0,36 & 7 & 0,29 \\
\hline Labidus mars & 1 & 0,02 & 1 & 0,04 \\
\hline Labidus praedator & 6 & 0,13 & 14 & 0,58 \\
\hline Neivamyrmex pseudops & 0 & 0 & 2 & 0,08 \\
\hline Neivamyrmex sp.01 & 3 & 0,07 & 3 & 0,13 \\
\hline Neivamyrmex sp.02 & 0 & 0 & 3 & 0,13 \\
\hline Neivamyrmex sp.04 & 1 & 0,02 & 1 & 0,04 \\
\hline Neivamyrmex sp.05 & 0 & 0 & 1 & 0,04 \\
\hline Neivamyrmex sp.06 & 1 & 0,02 & 0 & 0 \\
\hline Neivamyrmex sp.07 & 1 & 0,02 & 0 & 0 \\
\hline $\begin{array}{l}\text { Nomamyrmex esenbeckii } \\
\text { wilsoni }\end{array}$ & 0 & 0 & 1 & 0,04 \\
\hline Ectatomminae & 26 & 0,58 & 65 & 2,71 \\
\hline Ectatomma brunneum & 24 & 0,53 & 13 & 0,54 \\
\hline Ectatomma edentatum & 0 & 0 & 29 & 1,21 \\
\hline Ectatomma opaciventris & 2 & 0,04 & 6 & 0,25 \\
\hline Ectatomma permagnum & 0 & 0 & 14 & 0,58 \\
\hline Ectatomma planidens & 0 & 0 & 1 & 0,04 \\
\hline Ectatomma tuberculatum & 0 & 0 & 2 & 0,08 \\
\hline
\end{tabular}

continua... 


\begin{tabular}{|c|c|c|c|c|}
\hline \multirow[b]{2}{*}{ Subfamílias/Espécies } & \multicolumn{2}{|c|}{ Agrossistemas } & \multicolumn{2}{|c|}{ Vegetacão nativa } \\
\hline & Ocorrências & $\begin{array}{l}\mathrm{N}^{\circ} \text { médio de } \\
\text { registros por } \\
\text { localidade }\end{array}$ & Ocorrências & $\begin{array}{l}\mathrm{N}^{\circ} \text { médio de } \\
\text { registros por } \\
\text { localidade }\end{array}$ \\
\hline Formicinae & 357 & 7,93 & 636 & 26,5 \\
\hline Acropyga sp.01 & 1 & 0,02 & 4 & 0,17 \\
\hline Acropyga sp.02 & 0 & 0 & 3 & 0,13 \\
\hline Acropyga sp.03 & 1 & 0,02 & 0 & 0 \\
\hline Brachymyrmex cf. delabiei & 0 & 0 & 7 & 0,29 \\
\hline Brachymyrmex pilipes & 0 & 0 & 1 & 0,04 \\
\hline Brachymyrmex sp.01 & 12 & 0,27 & 45 & 1,88 \\
\hline Brachymyrmex sp.02 & 0 & 0 & 1 & 0,04 \\
\hline Brachymyrmex sp.03 & 116 & 2,58 & 45 & 1,88 \\
\hline Brachymyrmex sp.04 & 2 & 0,04 & 5 & 0,21 \\
\hline Brachymyrmex sp.05 & 1 & 0,02 & 8 & 0,33 \\
\hline Brachymyrmex sp.07 & 0 & 0 & 4 & 0,17 \\
\hline Brachymyrmex sp.08 & 0 & 0 & 3 & 0,13 \\
\hline Brachymyrmex sp.09 & 0 & 0 & 1 & 0,04 \\
\hline Brachymyrmex sp.10 & 0 & 0 & 4 & 0,17 \\
\hline Camponotus arboreus & 1 & 0,02 & 2 & 0,08 \\
\hline Camponotus atriceps & 8 & 0,18 & 12 & 0,5 \\
\hline Camponotus bidens & 0 & 0 & 2 & 0,08 \\
\hline Camponotus bonarensis & 0 & 0 & 2 & 0,08 \\
\hline Camponotus cingulatus & 18 & 0,4 & 33 & 1,38 \\
\hline Camponotus gr. blandus & 11 & 0,24 & 48 & 2 \\
\hline Camponotus gr. senex & 30 & 0,67 & 57 & 2,38 \\
\hline Camponotus lespesii & 0 & 0 & 11 & 0,46 \\
\hline Camponotus leydigi & 4 & 0,09 & 3 & 0,13 \\
\hline Camponotus novagrandensis & 2 & 0,04 & 45 & 1,88 \\
\hline Camponotus personatus & 5 & 0,11 & 26 & 1,08 \\
\hline Camponotus renggeri & 1 & 0,02 & 14 & 0,58 \\
\hline Camponotus rufipes & 23 & 0,51 & 40 & 1,67 \\
\hline Camponotus sericeiventris & 2 & 0,04 & 5 & 0,21 \\
\hline Camponotus sp.12 & 65 & 1,44 & 55 & 2,29 \\
\hline Camponotus sp. 17 & 0 & 0 & 2 & 0,08 \\
\hline Camponotus sp.18 & 8 & 0,18 & 15 & 0,63 \\
\hline Camponotus sp. 26 & 0 & 0 & 1 & 0,04 \\
\hline Camponotus sp.27 & 0 & 0 & 3 & 0,13 \\
\hline Camponotus sp.28 & 0 & 0 & 1 & 0,04 \\
\hline Camponotus sp.29 & 1 & 0,02 & 4 & 0,17 \\
\hline Camponotus sp. 30 & 0 & 0 & 1 & 0,04 \\
\hline Camponotus sp. 32 & 0 & 0 & 1 & 0,04 \\
\hline Camponotus sp.34 & 0 & 0 & 1 & 0,04 \\
\hline Camponotus sp. 35 & 0 & 0 & 1 & 0,04 \\
\hline Camponotus sp.44 & 0 & 0 & 1 & 0,04 \\
\hline Camponotus sp.45 & 0 & 0 & 2 & 0,08 \\
\hline Camponotus sp.16 & 16 & 0,36 & 53 & 2,21 \\
\hline
\end{tabular}

continua... 


\begin{tabular}{|c|c|c|c|c|}
\hline \multirow[b]{2}{*}{ Subfamílias/Espécies } & \multicolumn{2}{|c|}{ Agrossistemas } & \multicolumn{2}{|c|}{ Vegetação nativa } \\
\hline & Ocorrências & $\begin{array}{l}\mathrm{N}^{\circ} \text { médio de } \\
\text { registros por } \\
\text { localidade }\end{array}$ & Ocorrências & $\begin{array}{l}\mathrm{N}^{\circ} \text { médio de } \\
\text { registros por } \\
\text { localidade }\end{array}$ \\
\hline Camponotus substitutus & 0 & 0 & 10 & 0,42 \\
\hline Nylanderia sp.01 & 6 & 0,13 & 42 & 1,75 \\
\hline Nylanderia sp.03 & 22 & 0,49 & 0 & 0 \\
\hline Nylanderia sp.04 & 0 & 0 & 10 & 0,42 \\
\hline Prionopelta punctulata & 1 & 0,02 & 1 & 0,04 \\
\hline Prionopelta sp.02 & 0 & 0 & 1 & 0,04 \\
\hline Heteroponerinae & 0 & 0 & 3 & 0,13 \\
\hline Heteroponera dolo & 0 & 0 & 3 & 0,13 \\
\hline Myrmicinae & 1693 & 37,62 & 1381 & 57,54 \\
\hline Acromyrmex cf. balzani & 1 & 0,02 & 3 & 0,13 \\
\hline Acromyrmex sp.01 & 5 & 0,11 & 22 & 0,92 \\
\hline Acromyrmex sp.02 & 0 & 0 & 2 & 0,08 \\
\hline Acromyrmex sp.03 & 4 & 0,09 & 16 & 0,67 \\
\hline Apterostigma sp.01 & 1 & 0,02 & 11 & 0,46 \\
\hline Apterostigma sp.02 & 1 & 0,02 & 3 & 0,13 \\
\hline Atta sp.01 & 20 & 0,44 & 14 & 0,58 \\
\hline Basiceros sp.01 & 0 & 0 & 1 & 0,04 \\
\hline Blepharidatta conops & 0 & 0 & 3 & 0,13 \\
\hline Cardiocondyla emeryi & 40 & 0,89 & 0 & 0 \\
\hline Cardiocondyla sp.01 & 3 & 0,07 & 0 & 0 \\
\hline Carebara brevipilosa & 0 & 0 & 7 & 0,29 \\
\hline Carebara urichi & 1 & 0,02 & 1 & 0,04 \\
\hline Cephalotes atratus & 0 & 0 & 1 & 0,04 \\
\hline Cephalotes betoi & 0 & 0 & 2 & 0,08 \\
\hline Cephalotes maculatus & 0 & 0 & 1 & 0,04 \\
\hline Cephalotes pusillus & 4 & 0,09 & 3 & 0,13 \\
\hline Crematogaster limata & 0 & 0 & 30 & 1,25 \\
\hline Crematogaster sp.01 & 2 & 0,04 & 10 & 0,42 \\
\hline Crematogaster sp.02 & 0 & 0 & 3 & 0,13 \\
\hline Crematogaster sp.03 & 0 & 0 & 8 & 0,33 \\
\hline Crematogaster sp.04 & 0 & 0 & 2 & 0,08 \\
\hline Crematogaster sp.05 & 0 & 0 & 24 & 1 \\
\hline Crematogaster sp.06 & 22 & 0,49 & 20 & 0,83 \\
\hline Crematogaster sp.08 & 0 & 0 & 2 & 0,08 \\
\hline Crematogaster sp.10 & 0 & 0 & 7 & 0,29 \\
\hline Crematogaster sp.11 & 1 & 0,02 & 4 & 0,17 \\
\hline Crematogaster sp.13 & 0 & 0 & 1 & 0,04 \\
\hline Crematogaster sp.14 & 0 & 0 & 1 & 0,04 \\
\hline Cyatta abscondita & 0 & 0 & 1 & 0,04 \\
\hline Cyphomyrmex lectus & 0 & 0 & 7 & 0,29 \\
\hline Cyphomyrmex rimosus & 28 & 0,62 & 8 & 0,33 \\
\hline Cyphomyrmex sp04 gr. rimosus & 1 & 0,02 & 12 & 0,5 \\
\hline Cyphomyrmex sp05 gr. rimosus & 8 & 0,18 & 4 & 0,17 \\
\hline
\end{tabular}

continua... 


\begin{tabular}{|c|c|c|c|c|}
\hline \multirow[b]{2}{*}{ Subfamílias/Espécies } & \multicolumn{2}{|c|}{ Agrossistemas } & \multicolumn{2}{|c|}{ Vegetação nativa } \\
\hline & Ocorrências & $\begin{array}{l}\mathrm{N}^{\circ} \text { médio de } \\
\text { registros por } \\
\text { localidade }\end{array}$ & Ocorrências & $\begin{array}{l}\mathrm{N}^{\circ} \text { médio de } \\
\text { registros por } \\
\text { localidade }\end{array}$ \\
\hline Cyphomyrmex sp06 gr. rimosus & 1 & 0,02 & 5 & 0,21 \\
\hline $\begin{array}{l}\text { Cyphomyrmex sp.09 gr. } \\
\text { strigatus }\end{array}$ & 0 & 0 & 1 & 0,04 \\
\hline $\begin{array}{l}\text { Cyphomyrmex sp.10 gr. } \\
\text { strigatus }\end{array}$ & 0 & 0 & 1 & 0,04 \\
\hline Gnamptogenys acuminata & 1 & 0,02 & 0 & 0 \\
\hline Gnamptogenys cf. bruchi & 0 & 0 & 1 & 0,04 \\
\hline Gnamptogenys cf. rastrata & 2 & 0,04 & 0 & 0 \\
\hline Gnamptogenys sp.01 & 2 & 0,04 & 28 & 1,17 \\
\hline Gnamptogenys sp.03 & 0 & 0 & 3 & 0,13 \\
\hline Gnamptogenys sp.06 & 0 & 0 & 1 & 0,04 \\
\hline Gnamptogenys sulcata & 23 & 0,51 & 6 & 0,25 \\
\hline Hylomyrma sp.02 & 0 & 0 & 5 & 0,21 \\
\hline Hylomyrma sp.03 & 0 & 0 & 1 & 0,04 \\
\hline Megalomyrmex silvestrii & 2 & 0,04 & 0 & 0 \\
\hline Megalomyrmex sp.02 & 0 & 0 & 1 & 0,04 \\
\hline Monomorium floricola & 1 & 0,02 & 0 & 0 \\
\hline Mycetarotes cf. parallelus & 0 & 0 & 1 & 0,04 \\
\hline Mycetarotes sp.02 & 0 & 0 & 1 & 0,04 \\
\hline Mycocepurus goeldii & 29 & 0,64 & 12 & 0,5 \\
\hline Mycocepurus obsoletus & 0 & 0 & 11 & 0,46 \\
\hline Mycocepurus sp.03 & 14 & 0,31 & 3 & 0,13 \\
\hline Mycocepurus sp.04 & 2 & 0,04 & 1 & 0,04 \\
\hline Myrmicocrypta camargoi & 1 & 0,02 & 0 & 0 \\
\hline Myrmicocrypta sp.01 & 4 & 0,09 & 7 & 0,29 \\
\hline Myrmicocrypta sp.03 & 0 & 0 & 1 & 0,04 \\
\hline Ochetomyrmex semipolitus & 0 & 0 & 6 & 0,25 \\
\hline Octostruma sp.01 & 0 & 0 & 2 & 0,08 \\
\hline Oxyepoecus cf. vezenyii & 0 & 0 & 1 & 0,04 \\
\hline Oxyepoecus sp.02 & 1 & 0,02 & 1 & 0,04 \\
\hline Oxyepoecus sp.03 & 1 & 0,02 & 0 & 0 \\
\hline Pheidole gertrudae & 155 & 3,44 & 70 & 2,92 \\
\hline Pheidole gr. fimbriata & 1 & 0,02 & 1 & 0,04 \\
\hline Pheidole sp.02 & 38 & 0,84 & 3 & 0,13 \\
\hline Pheidole sp.03 & 63 & 1,4 & 85 & 3,54 \\
\hline Pheidole sp.04 & 68 & 1,51 & 0 & 0 \\
\hline Pheidole sp.05 & 49 & 1,09 & 3 & 0,13 \\
\hline Pheidole sp.06 & 0 & 0 & 8 & 0,33 \\
\hline Pheidole sp.07 & 10 & 0,22 & 1 & 0,04 \\
\hline Pheidole sp.08 & 0 & 0 & 16 & 0,67 \\
\hline Pheidole sp.09 & 51 & 1,13 & 0 & 0 \\
\hline Pheidole sp.10 & 3 & 0,07 & 13 & 0,54 \\
\hline Pheidole sp.11 & 43 & 0,96 & 13 & 0,54 \\
\hline
\end{tabular}

continua... 


\begin{tabular}{|c|c|c|c|c|}
\hline \multirow[b]{2}{*}{ Subfamílias/Espécies } & \multicolumn{2}{|c|}{ Agrossistemas } & \multicolumn{2}{|c|}{ Vegetação nativa } \\
\hline & Ocorrências & $\begin{array}{l}\mathrm{N}^{\circ} \text { médio de } \\
\text { registros por } \\
\text { localidade }\end{array}$ & Ocorrências & $\begin{array}{l}\mathrm{N}^{\circ} \text { médio de } \\
\text { registros por } \\
\text { localidade }\end{array}$ \\
\hline Pheidole sp.13 & 97 & 2,16 & 59 & 2,46 \\
\hline Pheidole sp.16 & 19 & 0,42 & 0 & 0 \\
\hline Pheidole sp.17 & 2 & 0,04 & 3 & 0,13 \\
\hline Pheidole sp.18 & 1 & 0,02 & 1 & 0,04 \\
\hline Pheidole sp.19 & 7 & 0,16 & 62 & 2,58 \\
\hline Pheidole sp.21 & 0 & 0 & 4 & 0,17 \\
\hline Pheidole sp.23 & 15 & 0,33 & 8 & 0,33 \\
\hline Pheidole sp.24 & 70 & 1,56 & 1 & 0,04 \\
\hline Pheidole sp.25 & 0 & 0 & 7 & 0,29 \\
\hline Pheidole sp.26 & 0 & 0 & 33 & 1,38 \\
\hline Pheidole sp.27 & 3 & 0,07 & 0 & 0 \\
\hline Pheidole sp.28 & 7 & 0,16 & 4 & 0,17 \\
\hline Pheidole sp.29 & 8 & 0,18 & 0 & 0 \\
\hline Pheidole sp.31 & 0 & 0 & 7 & 0,29 \\
\hline Pheidole sp.33 & 0 & 0 & 10 & 0,42 \\
\hline Pheidole sp.35 & 24 & 0,53 & 0 & 0 \\
\hline Pheidole sp.36 & 0 & 0 & 1 & 0,04 \\
\hline Pheidole sp.38 & 0 & 0 & 4 & 0,17 \\
\hline Pheidole sp.39 & 1 & 0,02 & 0 & 0 \\
\hline Pheidole sp.40 & 2 & 0,04 & 0 & 0 \\
\hline Pheidole sp.41 & 3 & 0,07 & 1 & 0,04 \\
\hline Pheidole sp.42 & 10 & 0,22 & 9 & 0,38 \\
\hline Pheidole sp.44 & 0 & 0 & 1 & 0,04 \\
\hline Pheidole sp.45 & 0 & 0 & 3 & 0,13 \\
\hline Pheidole sp46 & 0 & 0 & 1 & 0,04 \\
\hline Pheidole sp.47 & 1 & 0,02 & 0 & 0 \\
\hline Pheidole sp.48 & 0 & 0 & 1 & 0,04 \\
\hline Pheidole sp.49 & 8 & 0,18 & 5 & 0,21 \\
\hline Pheidole sp.50 & 0 & 0 & 3 & 0,13 \\
\hline Pheidole sp.01 & 184 & 4,09 & 187 & 7,79 \\
\hline Pheidole sp.20 & 63 & 1,4 & 33 & 1,38 \\
\hline Pheidole sp.22 & 58 & 1,29 & 51 & 2,13 \\
\hline Pogonomyrmex naegile & 11 & 0,24 & 14 & 0,58 \\
\hline Rogeria sp.01 & 2 & 0,04 & 6 & 0,25 \\
\hline Rogeria sp.02 & 0 & 0 & 1 & 0,04 \\
\hline Sericomyrmex sp.01 & 0 & 0 & 6 & 0,25 \\
\hline Sericomyrmex sp.02 & 0 & 0 & 1 & 0,04 \\
\hline Solenopsis cf. loretana & 2 & 0,04 & 0 & 0 \\
\hline Solenopsis globularia & 1 & 0,02 & 2 & 0,08 \\
\hline Solenopsis saevissima & 141 & 3,13 & 13 & 0,54 \\
\hline Solenopsis sp.03 & 4 & 0,09 & 26 & 1,08 \\
\hline Solenopsis sp.04 pr. loretana & 67 & 1,49 & 0 & 0 \\
\hline Solenopsis sp.08 & 6 & 0,13 & 4 & 0,17 \\
\hline
\end{tabular}

continua... 


\begin{tabular}{|c|c|c|c|c|}
\hline \multirow[b]{2}{*}{ Subfamílias/Espécies } & \multicolumn{2}{|c|}{ Agrossistemas } & \multicolumn{2}{|c|}{ Vegetação nativa } \\
\hline & Ocorrências & $\begin{array}{l}\mathrm{N}^{\circ} \text { médio de } \\
\text { registros por } \\
\text { localidade }\end{array}$ & Ocorrências & $\begin{array}{l}\mathrm{N}^{\circ} \text { médio de } \\
\text { registros por } \\
\text { localidade }\end{array}$ \\
\hline Solenopsis sp.11 & 0 & 0 & 1 & 0,04 \\
\hline Solenopsis sp. 12 & 1 & 0,02 & 0 & 0 \\
\hline Solenopsis sp.13 & 0 & 0 & 4 & 0,17 \\
\hline Solenopsis sp.14 & 0 & 0 & 1 & 0,04 \\
\hline Solenopsis sp.15 & 0 & 0 & 1 & 0,04 \\
\hline Solenopsis sp.16 gr. molesta & 1 & 0,02 & 0 & 0 \\
\hline Solenopsis sp. 17 gr. wasmannii & 1 & 0,02 & 2 & 0,08 \\
\hline Solenopsis sp.18 & 0 & 0 & 1 & 0,04 \\
\hline Solenopsis sp.01 & 82 & 1,82 & 115 & 4,79 \\
\hline Solenopsis sp.02 & 20 & 0,44 & 28 & 1,17 \\
\hline Solenopsis tridens & 6 & 0,13 & 14 & 0,58 \\
\hline Strumygenys sp.01 & 2 & 0,04 & 5 & 0,21 \\
\hline Strumygenys sp.02 & 10 & 0,22 & 0 & 0 \\
\hline Strumygenys sp.03 & 0 & 0 & 3 & 0,13 \\
\hline Strumygenys sp.04 & 1 & 0,02 & 0 & 0 \\
\hline Strumygenys sp.05 & 0 & 0 & 1 & 0,04 \\
\hline Strumygenys sp.06 & 1 & 0,02 & 2 & 0,08 \\
\hline Strumygenys sp.07 & 0 & 0 & 1 & 0,04 \\
\hline Tetramorium cf. similum & 10 & 0,22 & 0 & 0 \\
\hline Trachymyrmex sp.01 & 4 & 0,09 & 2 & 0,08 \\
\hline Trachymyrmex sp.02 & 4 & 0,09 & 0 & 0 \\
\hline Trachymyrmex sp.03 & 4 & 0,09 & 9 & 0,38 \\
\hline Trachymyrmex sp.04 & 0 & 0 & 1 & 0,04 \\
\hline Trachymyrmex sp.05 & 0 & 0 & 7 & 0,29 \\
\hline Trachymyrmex sp.06 & 0 & 0 & 2 & 0,08 \\
\hline Trachymyrmex sp.07 & 0 & 0 & 3 & 0,13 \\
\hline Trachymyrmex sp.08 & 5 & 0,11 & 0 & 0 \\
\hline Trachymyrmex sp.09 & 0 & 0 & 2 & 0,08 \\
\hline Trachymyrmex sp.10 & 1 & 0,02 & 0 & 0 \\
\hline Typhlomyrmex pusillus & 1 & 0,02 & 0 & 0 \\
\hline Wasmannia auropunctata & 12 & 0,27 & 52 & 2,17 \\
\hline Wasmannia sp.02 & 2 & 0,04 & 5 & 0,21 \\
\hline Wasmannia sp.03 & 1 & 0,02 & 0 & 0 \\
\hline
\end{tabular}

continua... 


\begin{tabular}{|c|c|c|c|c|}
\hline \multirow[b]{2}{*}{ Subfamílias/Espécies } & \multicolumn{2}{|c|}{ Agrossistemas } & \multicolumn{2}{|c|}{ Vegetação nativa } \\
\hline & Ocorrências & $\begin{array}{l}\mathrm{N}^{\circ} \text { médio de } \\
\text { registros por } \\
\text { localidade }\end{array}$ & Ocorrências & $\begin{array}{l}\mathrm{N}^{\circ} \text { médio de } \\
\text { registros por } \\
\text { localidade }\end{array}$ \\
\hline Ponerinae & 158 & 3,51 & 178 & 7,42 \\
\hline Anochetus inermis & 9 & 0,2 & 1 & 0,04 \\
\hline Centromyrmex brachycola & 0 & 0 & 1 & 0,04 \\
\hline Centromyrmex gigas & 0 & 0 & 1 & 0,04 \\
\hline Dinoponera australis & 0 & 0 & 2 & 0,08 \\
\hline Hypoponera cf. foreli & 0 & 0 & 4 & 0,17 \\
\hline Hypoponera sp.01 & 36 & 0,8 & 14 & 0,58 \\
\hline Hypoponera sp.03 & 7 & 0,16 & 0 & 0 \\
\hline Hypoponera sp.04 & 3 & 0,07 & 0 & 0 \\
\hline Hypoponera sp.05 & 3 & 0,07 & 0 & 0 \\
\hline Hypoponera sp.06 & 3 & 0,07 & 4 & 0,17 \\
\hline Hypoponera sp.07 & 4 & 0,09 & 2 & 0,08 \\
\hline Hypoponera sp.08 & 17 & 0,38 & 0 & 0 \\
\hline Neoponera marginata & 4 & 0,09 & 1 & 0,04 \\
\hline Neoponera verenae & 37 & 0,82 & 43 & 1,79 \\
\hline Odontomachus bauri & 13 & 0,29 & 9 & 0,38 \\
\hline Odontomachus chelifer & 1 & 0,02 & 30 & 1,25 \\
\hline Odontomachus laticeps & 0 & 0 & 11 & 0,46 \\
\hline Odontomachus sp.05 & 0 & 0 & 3 & 0,13 \\
\hline Pachycondyla harpax & 14 & 0,31 & 29 & 1,21 \\
\hline Pachycondyla sp.03 & 0 & 0 & 1 & 0,04 \\
\hline Pachycondyla striata & 7 & 0,16 & 17 & 0,71 \\
\hline Rasopone sp.01 & 0 & 0 & 5 & 0,21 \\
\hline Pseudomyrmecinae & 12 & 0,27 & 39 & 1,63 \\
\hline Pseudomyrmex cf. phyllophilus & 1 & 0,02 & 1 & 0,04 \\
\hline Pseudomyrmex gracilis & 0 & 0 & 1 & 0,04 \\
\hline Pseudomyrmex pallidus & 1 & 0,02 & 11 & 0,46 \\
\hline Pseudomyrmex tenuis & 0 & 0 & 5 & 0,21 \\
\hline Pseudomyrmex termitarius & 10 & 0,22 & 21 & 0,88 \\
\hline Total Geral & 2529 & 56,2 & 2480 & 103,33 \\
\hline
\end{tabular}




\section{Anexo III.}

Soja

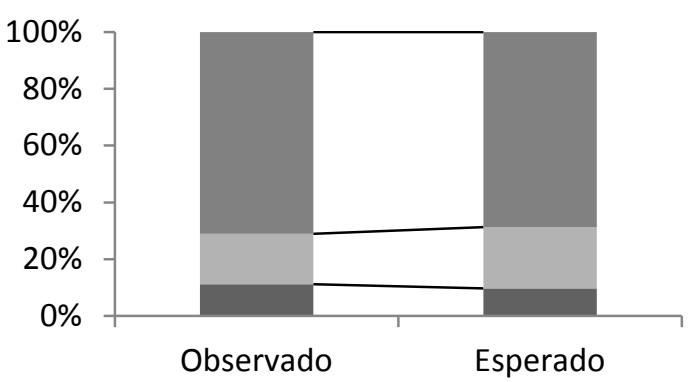

Agricultura orgânica

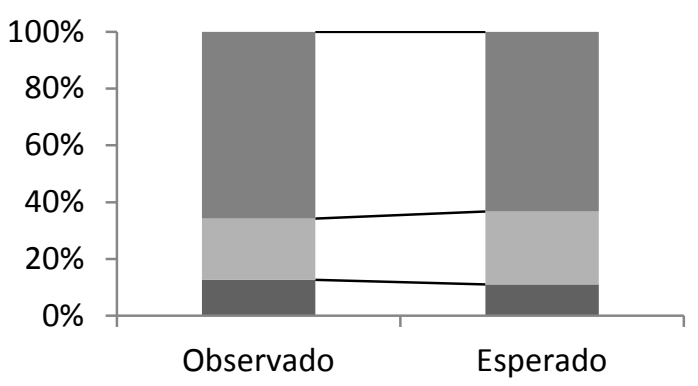

Pastagem

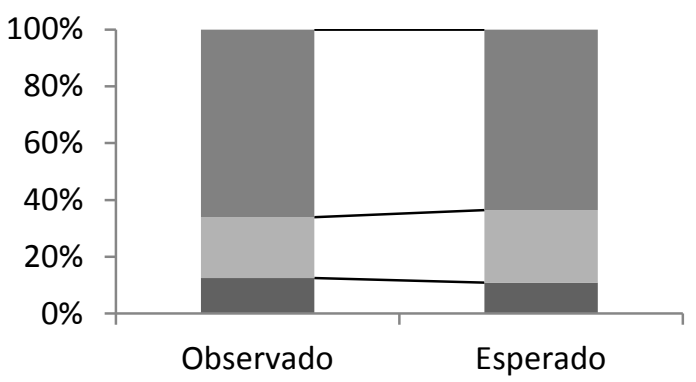

Agrossistemas

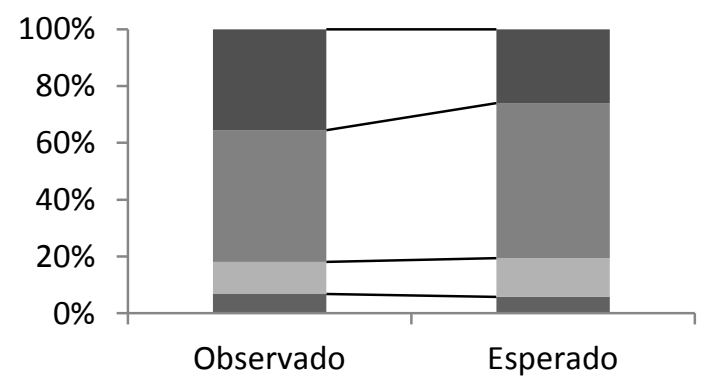

Campo

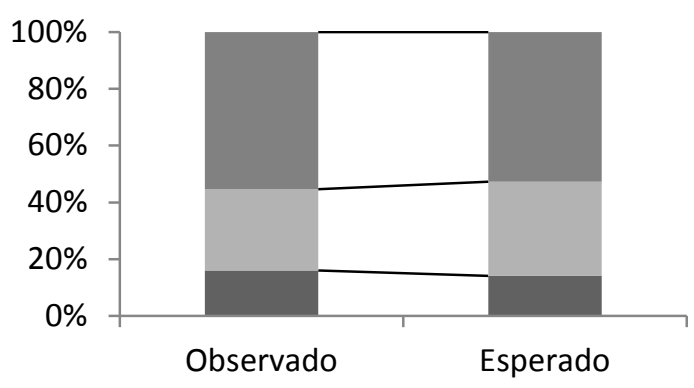

Cerrado

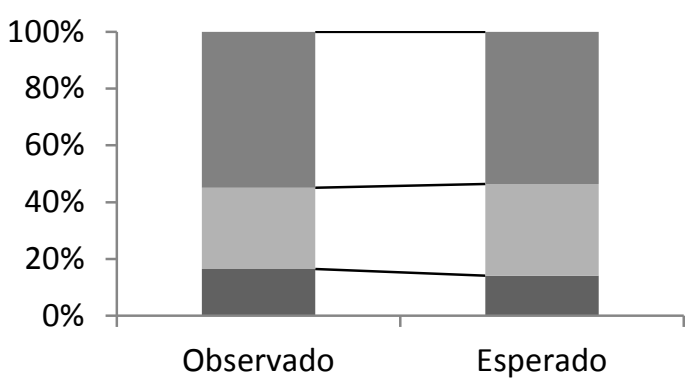

Mata

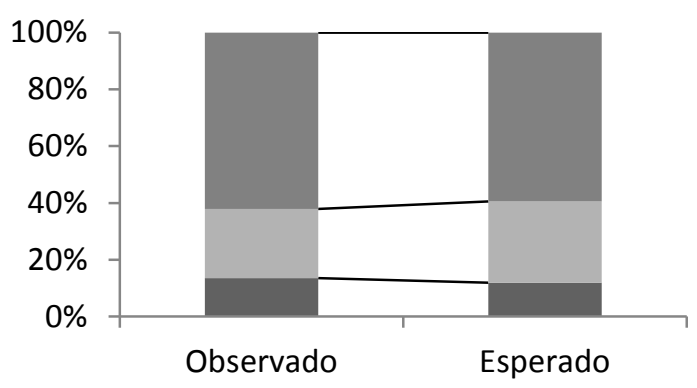

Vegetação nativa

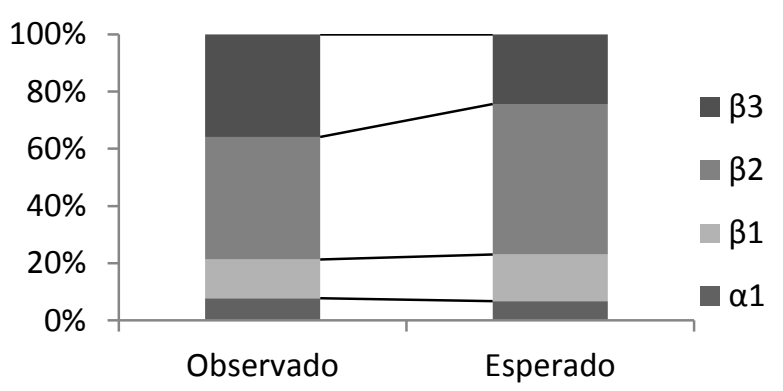

Figuras das análises de partição aditiva de diversidade de formigas no Distrito Federal separada por tipo de sistema agrícola ou fitofisionomia da vegetação nativa. $\alpha 1$ é quantidade de espécies por parcela. $\beta 1$ é a troca de espécies entre parcelas dentro da mesma localidade. $\beta 2$ é a troca de espécies entre localidades pertencentes ao mesmo tipo de agrossistema ou fitofísionomia. $\beta 3$ é a troca de espécies entre os diferentes tipos de agrossistemas e fitofisionomias. 
Anexo IV.

Lista de espécies capturadas dentro das estações de remoção de biomassa e ordenadas por sua ocorrência.

\begin{tabular}{|c|c|c|c|c|}
\hline Espécies & Banana & Sardinha & Semente & $\begin{array}{c}\text { Frequequência acumulada } \\
\text { de ocorrência }\end{array}$ \\
\hline Pheidole sp. 01 & 74 & 94 & 31 & $10,7 \%$ \\
\hline Pheidole gertrudae & 48 & 78 & 13 & $18,1 \%$ \\
\hline Solenopsis saevissima & 33 & 44 & 18 & $23,2 \%$ \\
\hline Solenopsis sp. 01 & 15 & 54 & 15 & $27,8 \%$ \\
\hline Pheidole sp. 13 & 29 & 32 & 8 & $31,5 \%$ \\
\hline Pheidole sp. 03 & 17 & 41 & 10 & $35,1 \%$ \\
\hline Pheidole sp. 20 & 20 & 33 & 13 & $38,6 \%$ \\
\hline Brachymyrmex sp. 03 & 19 & 40 & 3 & $42,0 \%$ \\
\hline Camponotus sp. 12 & 14 & 24 & 10 & $44,6 \%$ \\
\hline Dorymyrmex cf. brunneus & 18 & 23 & 5 & $47,0 \%$ \\
\hline Pheidole sp. 19 & 12 & 10 & 18 & $49,2 \%$ \\
\hline Camponotus gr. blandus & 4 & 27 & 7 & $51,2 \%$ \\
\hline Camponotus sp. 16 & 5 & 25 & 8 & $53,2 \%$ \\
\hline Pheidole sp. 05 & 11 & 16 & 11 & $55,3 \%$ \\
\hline Camponotus gr. senex & 12 & 20 & 3 & $57,2 \%$ \\
\hline Pheidole sp. 24 & 21 & 5 & 7 & $58,9 \%$ \\
\hline Pheidole sp. 04 & 12 & 17 & 3 & $60,7 \%$ \\
\hline Pheidole sp. 22 & 16 & 13 & 3 & $62,4 \%$ \\
\hline Camponotus rufipes & 3 & 19 & 8 & $64,0 \%$ \\
\hline Solenopsis sp. 03 & 11 & 11 & 8 & $65,6 \%$ \\
\hline Camponotus novagrandensis & 3 & 21 & 5 & $67,1 \%$ \\
\hline Linepithema cf. neotropicum & 13 & 11 & 5 & $68,7 \%$ \\
\hline Crematogaster limata & 9 & 15 & 2 & $70,1 \%$ \\
\hline Pheidole sp. 02 & 5 & 16 & 2 & $71,3 \%$ \\
\hline Camponotus cingulatus & 5 & 15 & 2 & $72,5 \%$ \\
\hline Crematogaster sp. 05 & 5 & 12 & 5 & $73,7 \%$ \\
\hline Crematogaster sp. 06 & 3 & 15 & 3 & $74,8 \%$ \\
\hline Wasmannia auropunctata & 8 & 6 & 5 & $75,8 \%$ \\
\hline Brachymyrmex sp. 01 & 5 & 10 & 2 & $76,8 \%$ \\
\hline Camponotus personatus & 6 & 3 & 8 & $77,7 \%$ \\
\hline Linepithema cf. cerradense & 9 & 7 & 1 & $78,6 \%$ \\
\hline Acromyrmex sp. 01 & 10 & & 5 & $79,4 \%$ \\
\hline Pheidole sp. 11 & 6 & 7 & 2 & $80,2 \%$ \\
\hline Nylanderia sp. 01 & 5 & 7 & & $80,8 \%$ \\
\hline Nylanderia sp. 03 & 3 & 6 & 3 & $81,5 \%$ \\
\hline Pheidole sp. 26 & 6 & 4 & 2 & $82,1 \%$ \\
\hline Solenopsis sp. 04 pr. loretana & 4 & 6 & 2 & $82,8 \%$ \\
\hline Pheidole sp. 09 & 1 & 9 & 1 & $83,4 \%$ \\
\hline Camponotus sp. 18 & 2 & 5 & 3 & $83,9 \%$ \\
\hline Dorymyrmex sp. 01 & 4 & 5 & 1 & $84,4 \%$ \\
\hline Pheidole sp. 23 & 1 & 6 & 2 & $84,9 \%$ \\
\hline Pseudomyrmex termitarius & 1 & 7 & 1 & $85,4 \%$ \\
\hline Acromyrmex sp. 03 & 6 & 1 & 1 & $85,8 \%$ \\
\hline Continua... & & & & \\
\hline
\end{tabular}




\begin{tabular}{|c|c|c|c|c|}
\hline Espécies & Banana & Sardinha & Semente & $\begin{array}{c}\text { Frequequência acumulada } \\
\text { de ocorrência }\end{array}$ \\
\hline Atta sp. 01 & & 8 & & $86,3 \%$ \\
\hline Camponotus atriceps & 2 & 5 & 1 & $86,7 \%$ \\
\hline Camponotus renggeri & 1 & 7 & & $87,1 \%$ \\
\hline Labidus praedator & 4 & 3 & 1 & $87,5 \%$ \\
\hline Pheidole sp. 16 & 2 & 6 & & $88,0 \%$ \\
\hline Ectatomma brunneum & 2 & 4 & 1 & $88,4 \%$ \\
\hline Labidus coecus & & 6 & 1 & $88,7 \%$ \\
\hline Linepithema sp. 05 & 2 & 5 & & $89,1 \%$ \\
\hline Cephalotes pusillus & 2 & 1 & 3 & $89,4 \%$ \\
\hline Crematogaster sp. 01 & & 5 & 1 & $89,7 \%$ \\
\hline Linepithema micans & 3 & 3 & & $90,1 \%$ \\
\hline Neoponera verenae & 1 & 2 & 3 & $90,4 \%$ \\
\hline Pheidole sp. 10 & 2 & 3 & 1 & $90,7 \%$ \\
\hline Solenopsis tridens & 2 & 3 & 1 & $91,0 \%$ \\
\hline Azteca sp. 02 & 1 & 4 & & $91,3 \%$ \\
\hline Crematogaster sp. 03 & 1 & 3 & 1 & $91,6 \%$ \\
\hline Crematogaster sp. 10 & 3 & 2 & & $91,8 \%$ \\
\hline Dorymyrmex cf. bituber & 3 & 2 & & $92,1 \%$ \\
\hline Linepithema cf. gallardoi & 3 & 2 & & $92,4 \%$ \\
\hline Linepithema cf. humile & 1 & 4 & & $92,6 \%$ \\
\hline Brachymyrmex sp. 05 & 1 & 2 & 1 & $92,9 \%$ \\
\hline Dorymyrmex cf. jheringi & 3 & 1 & & $93,1 \%$ \\
\hline Nylanderia sp. 04 & 3 & 1 & & $93,3 \%$ \\
\hline Pheidole sp. 06 & 3 & 1 & & $93,5 \%$ \\
\hline Pheidole sp. 08 & 2 & 1 & 1 & $93,7 \%$ \\
\hline Solenopsis sp. 02 & & 4 & & $93,9 \%$ \\
\hline Tetramorium cf. similum & 2 & 2 & & $94,1 \%$ \\
\hline Trachymyrmex sp. 03 & 3 & & 1 & $94,4 \%$ \\
\hline Camponotus sericeiventris & & 3 & & $94,5 \%$ \\
\hline Cardiocondyla emeryi & 2 & 1 & & $94,7 \%$ \\
\hline Dolichoderus bispinosus & 1 & 1 & 1 & $94,8 \%$ \\
\hline Pheidole sp. 07 & 1 & 2 & & $95,0 \%$ \\
\hline Pheidole sp. 28 & & 3 & & $95,2 \%$ \\
\hline Sericomyrmex sp. 01 & 1 & & 2 & $95,3 \%$ \\
\hline Solenopsis sp. 08 & 1 & 1 & 1 & $95,5 \%$ \\
\hline Azteca sp. 01 & & 2 & & $95,6 \%$ \\
\hline Camponotus arboreus & 1 & 1 & & $95,7 \%$ \\
\hline Camponotus bonarensis & & 2 & & $95,8 \%$ \\
\hline Camponotus sp. 17 & 1 & 1 & & $95,9 \%$ \\
\hline Camponotus substitutus & & 1 & 1 & $96,0 \%$ \\
\hline Crematogaster sp. 02 & & 2 & & $96,1 \%$ \\
\hline Ectatomma edentatum & 2 & & & $96,2 \%$ \\
\hline Gnamptogenys sp. 01 & 1 & 1 & & $96,3 \%$ \\
\hline Hypoponera sp. 01 & 1 & 1 & & $96,5 \%$ \\
\hline Continua... & & & & \\
\hline
\end{tabular}




\begin{tabular}{|c|c|c|c|c|}
\hline Espécies & Banana & Sardinha & Semente & $\begin{array}{c}\text { Frequequência acumulada } \\
\text { de ocorrência }\end{array}$ \\
\hline Odontomachus bauri & 2 & & & $96,6 \%$ \\
\hline Odontomachus chelifer & & 1 & 1 & $96,7 \%$ \\
\hline Pachycondyla harpax & & 2 & & $96,8 \%$ \\
\hline Pheidole sp. 17 & & 2 & & $96,9 \%$ \\
\hline Pheidole sp. 21 & & 2 & & $97,0 \%$ \\
\hline Pheidole sp. 29 & & & 2 & $97,1 \%$ \\
\hline Pheidole sp. 42 & 1 & 1 & & $97,2 \%$ \\
\hline Pogonomyrmex naegile & 1 & 1 & & $97,3 \%$ \\
\hline Pseudomyrmex cf. phyllophilus & & & 2 & $97,4 \%$ \\
\hline Pseudomyrmex pallidus & & 2 & & $97,5 \%$ \\
\hline Pseudomyrmex tenuis & 2 & & & $97,6 \%$ \\
\hline Solenopsis cf. loretana & 1 & 1 & & $97,7 \%$ \\
\hline Trachymyrmex sp. 02 & 2 & & & $97,9 \%$ \\
\hline Acromyrmex sp. 02 & & & 1 & $97,9 \%$ \\
\hline Apterostigma sp. 01 & & 1 & & $98,0 \%$ \\
\hline Blepharidatta conops & & 1 & & $98,0 \%$ \\
\hline Brachymyrmex cf. delabiei & & 1 & & $98,1 \%$ \\
\hline Brachymyrmex sp. 02 & 1 & & & $98,1 \%$ \\
\hline Brachymyrmex sp. 04 & & 1 & & $98,2 \%$ \\
\hline Brachymyrmex sp. 07 & 1 & & & $98,2 \%$ \\
\hline Camponotus lespesii & & 1 & & $98,3 \%$ \\
\hline Camponotus leydigi & & 1 & & $98,3 \%$ \\
\hline Camponotus sp. 26 & & & 1 & $98,4 \%$ \\
\hline Camponotus sp. 27 & 1 & & & $98,4 \%$ \\
\hline Camponotus sp. 29 & & 1 & & $98,5 \%$ \\
\hline Camponotus sp. 45 & & 1 & & $98,6 \%$ \\
\hline Carebara brevipilosa & & 1 & & $98,6 \%$ \\
\hline Cephalotes betoi & & 1 & & $98,7 \%$ \\
\hline Crematogaster sp. 04 & & & 1 & $98,7 \%$ \\
\hline Crematogaster sp. 08 & & & 1 & $98,8 \%$ \\
\hline Crematogaster sp. 11 & 1 & & & $98,8 \%$ \\
\hline Cyphomyrmex rimosus & 1 & & & $98,9 \%$ \\
\hline Ectatomma opaciventris & & 1 & & $98,9 \%$ \\
\hline Ectatomma tuberculatum & 1 & & & $99,0 \%$ \\
\hline Forelius sp. 01 & 1 & & & $99,0 \%$ \\
\hline Heteroponera dolo & & 1 & & $99,1 \%$ \\
\hline Hypoponera sp. 06 & 1 & & & $99,1 \%$ \\
\hline Linepithema iniquum & & 1 & & $99,2 \%$ \\
\hline Mycocepurus goeldii & & & 1 & $99,2 \%$ \\
\hline Neivamyrmex sp. 01 & & 1 & & $99,3 \%$ \\
\hline Ochetomyrmex semipolitus & & 1 & & $99,4 \%$ \\
\hline Odontomachus laticeps & 1 & & & $99,4 \%$ \\
\hline Pheidole sp. 18 & 1 & & & $99,5 \%$ \\
\hline Pheidole sp. 25 & & 1 & & $99,5 \%$ \\
\hline Continua... & & & & \\
\hline
\end{tabular}




\begin{tabular}{lcccc}
\hline Espécies & Banana & Sardinha & Semente & $\begin{array}{c}\text { Frequequência acumulada } \\
\text { de ocorrencia }\end{array}$ \\
\hline Pheidole sp. 27 & 1 & & & $99,6 \%$ \\
Pheidole sp. 31 & & 1 & & $99,6 \%$ \\
Pheidole sp. 44 & & 1 & & $99,7 \%$ \\
Pheidole sp. 49 & 1 & & & $99,7 \%$ \\
Solenopsis sp. 16 gr. molesta & & & 1 & $99,8 \%$ \\
Strumygenys sp. 01 & & & 1 & $99,8 \%$ \\
Tapinoma sp. 02 & 1 & & 1 & $99,9 \%$ \\
Trachymyrmex sp. 01 & 1 & & & $99,9 \%$ \\
Trachymyrmex sp. 04 & 1 & & $100,0 \%$ \\
\hline
\end{tabular}

